\title{
New Inscriptions from the Museum of Bursa
}

\author{
N. Eda AKYÜREK ŞAHİN* - Hüseyin UZUNOĞLU**
}

In this contribution we present some new ancient Greek inscriptions from the Bursa Museum. Of the 36 artefacts, the first four are dedications, while the remaining examples are funerary stones. Six funerary stelai do not bear any inscriptions, nevertheless they are included in the article. After having been produced in the local ateliers, these uninscribed stones were presumably never sold to the customers and they were never employed as funerary stones. Some of the inscribed artefacts in the article (nos. 21-25) have been recently been published by E. Laflı and H. Bru (2016) without having obtained any permission from the museum directory, whereas we were invited and officially given the authorisation to record all inscriptions housed in the museum. We have therefore decided to re-publish them and made corrigenda to their texts where needed. The provenance of some of the artefacts is unfortunately unknown, but in general they were brought to the museum from Bursa province and its environs, such as from the districts of Nilüfer, İnegöl, Orhaneli, Harmancik, Keles, Gemlik, Karacabey and Orhangazi, as well as from the province of Yalova. The exvotos are offered to Meter Taurene, Men Tauropoleites, Zeus Kersoullos and Apollon. The first two deities are not known in the region of Mysia, Bithynia or the surroundings and their epitheta imply that their places of worship are to be found in the south-southwest of Asia Minor. These dedications might have found their way to the Bursa museum probably through confiscation consequent from the illegal activities of the smugglers of antiquities.

The funerary stones presented in the article have diverse forms, i.e. sarcophagus, prismatic and cylindirical altar, stele with banquet scenes, and stele on altar, which indicate a rich typology in terms of funerary monuments. The inscriptions engraved on them also contribute to enriching

* Prof. Dr. Nalan Eda Akyürek Şahin, Akdeniz Üniversitesi, Edebiyat Fakültesi, Eskiçağ Dilleri ve Kültürleri Bölümü, Antalya, Turkey (edasahin@akdeniz.edu.tr).

** Dr. Hüseyin Uzunoğlu, Akdeniz Üniversitesi, Edebiyat Fakültesi, Eskiçağ Dilleri ve Kültürleri Bölümü, Antalya, Turkey (huseyinuzunoglu@gmail.com).

We, foremost, thank Mrs. Ebru Dumlupınar, the current director of the Bursa Museum as well as Mr. Enver Sağır and Mr. Sinan Özdizbay, the ex-directors of the museum for giving me (N. Eda Akyürek Şahin) permission to work on the epigraphic material for many years, as well as the archaeologists, Mrs. Koncagül Hançer, Mrs. Gökçen Ovacık Şeker and Mr. Selçuk Çaprak. My work in the museum is still ongoing and a comprehensive corpus including all the new material is in progress. We are grateful to Prof. Dr. Johannes Nollé (Munich) and to two anonymous reviewers for their insightful comments and suggestions. Needless to say, all remaining errors are ours. We further thank T. Michael P. Duggan (Antalya) for improving the English of this paper.

Ergün Laflı and Hadrien Bru have published some inscriptions from the museum without permission (2016), which are re-published here and some of them have been corrected and improved. Cf. also some inscribed stamps which were also published in an unauthorized way by Ergün Laflı and Maurizio Buora, Un Possibile Stampo per Anfore e Altri Stampi per Pane di età Mediobizantina dal Museo di Bursa, Le Iscrizioni con Funzioni Didascalico-Esplicativa: Committente, Destinatario, Contenuto e Descrizione dell'Oggetto nell' Instrumentum Inscriptum. Atti del Vi Incontro Instrumenta Inscripta, Aquileia (26-28 Marzo 2015), Trieste 2016, 351-358. 
the onomastics of the Mysia and Bithynia regions. However humble they may seem, these funerary inscriptions still provide some interesting information concerning, e.g., a freedman (no. 5), a new phyle called Protinia (no. 10) and a posthumous honouring of a woman doctor (no. 11). The inscriptions to a large extent date to the Roman Imperial Period, but there are also a few Hellenistic examples (no. 13, 19, 24, 25).

\section{Dedications}

\section{Dedication to Meter Taurene and Men Tauropeleites}

A small votive stele of marble; kept on public display inside the museum.

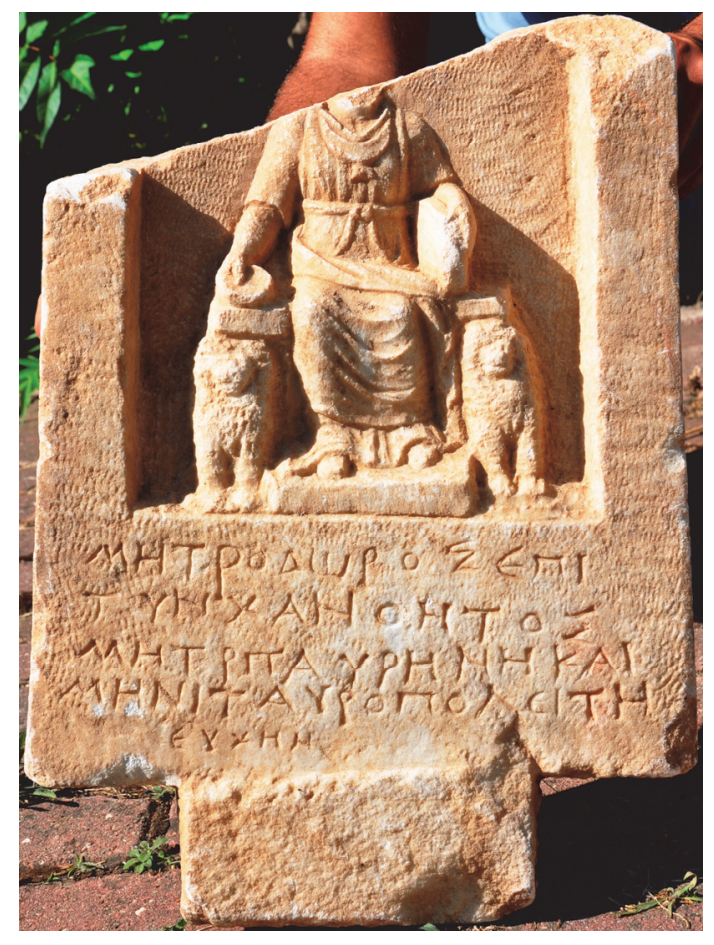

Inv. No.: 2013/58; findspot unknown. After being smuggled to İnegöl, the stele was seized there and transported to the museum following the judicial process. Dimensions: H.: 51 cm; W.: $38 \mathrm{~cm}$ (base); $35 \mathrm{~cm}$ (top); $20 \mathrm{~cm}$ (dowel); D.: 6,5-7 cm; Lh.: 1-3 cm.

The stele is broken at the top and the head of the goddess is missing due to this break. On the shaft of the stele the seated Meter figure on a throne is depicted; the throne is flanked by a lion on either side. The goddess holds a patera in her right hand and a tympanon (tambourine) in her left hand. She wears a chiton with a himation over it. Her feet are visible out of her long dress and she rests them on a rectangular footstool. Below this scene an untidy Greek inscription of five lines is carved. The stele has a somewhat thick and high dowel.

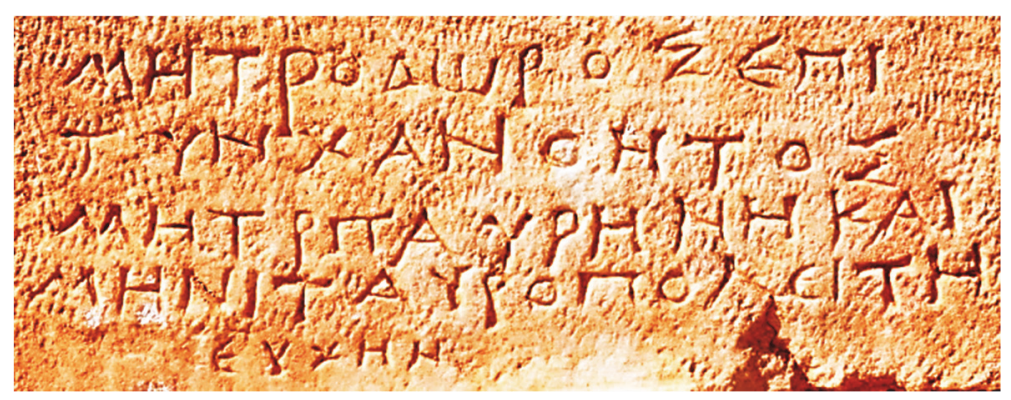

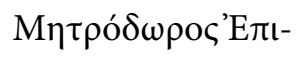

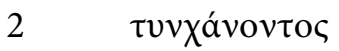

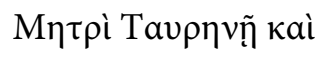

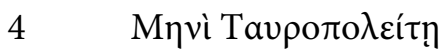

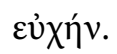

Metrodoros, son of Epitynchanon, (fulfilled) his vow to Meter Taurene and Men Tauropoleites. 


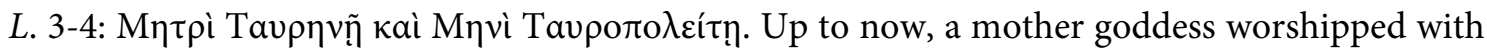
this epithet seems to be unknown. Yet, the epithet of Taurene attached to the goddess Ma occurs

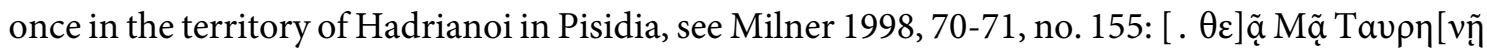
(?)]. Our new inscription indicates that the restoration by Milner of that dedication is more plausible than that made by G. E. Bean $(1959,95$, no. 43) who tentatively suggested Taurelatis or Tauregetis. It is also very possible that Meter Metaurene testified in Pisidia is in close relation with the Meter Taurene of our inscription. For Meter Metaurene see SEG 6, 619; Talloen 2015, 60 and 248. It is highly probable that both epitheta were derived from the Taurus mountains, and this is also supported by the fact that Meter is known as a goddess of the mountains, i.e. Meter Oreia, see Akın 2016 who compiled and evaluated all the evidence in Asia Minor (yet she doesn't mention Meter Metaurene in her work). Although it is not surprising that this cult is attested in Pisidia which is crossed by the western Taurus range, its occurence in Bithynia is rather astonishing. The inventory states that the artefact was transported from İnegöl, but its exact provenance is not recorded. Given the fact that the Bursa Museum houses numerous monuments of various provenances which found their way there as a result of smuggling (see for example Uzunoğlu 2019), it is not improbable that this stele originated from an area near the Western Taurus. That the god Men to whom this ex-vote is also offered bears the epithet of Tauropoleites gains a particular significance. To date, it is attested only once in Oinoanda as a designation of Ares, see Heberdey

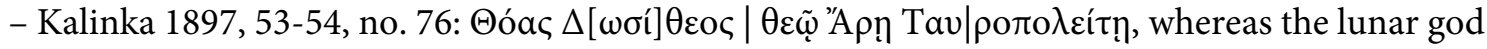
Men doesn't seem to have possessed this epithet according to our current knowledge. For all the known epitheta of Men, see Lane 1976, 67-80. Höfer (1916-1924, 137) claims that the epithet of Tauropoleites in the Oinoanda inscription is associated with the Carian city of Tauropolis men-

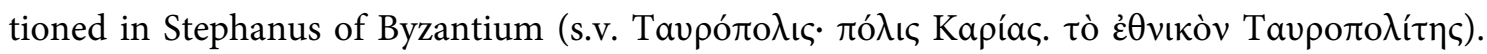
Although the exact location of that city has not been pinpointed to date, a passage in Constantinus Porphyrogennetos (de Them. 14) implies that it must be located somewhere in the Lycian-Carian borderland, see Ruge 1934, 33-34. So, although not certainly, it is possible that the provenance of our stele was somewhere in the mountainous area in the south-west Taurus Mountains. Never-

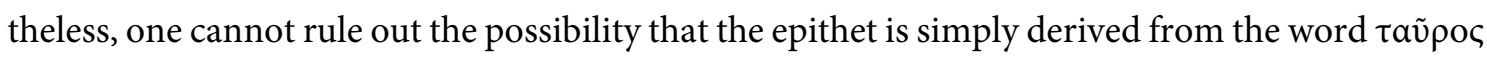
(= bull) or is somehow associated with the Iphigenia mythos, as is the case for Artemis Tauropoulos, see Nollé 2009.

It is highly probable that Metrodoros, who is named after the mother goddess, considered her as his guardian goddess. Thus this inscription provides a good example for the relation of the theophoric name-bearers with their patron deities.

For the examples of the juxtaposition of Meter and Men, see Lane 1976, 81-83.

Date: Roman Imperial Period

\section{Dedication to Zeus Kersoullos}

Column of grey marble. Inv. No.: 3051; findspot: unknown. Dimensions: H.: 189 cm; Diameter: (top) $25 \mathrm{~cm}$, (below) $34 \mathrm{~cm}$; Lh.: 2,2-3,5 cm.

The thin and long votive column has some partial breaks and cracks. On the rear part there are deep scratches. Otherwise well preserved, the column bears a Greek dedicatory inscription of eight lines. Some letters are barely legible due to erosion-abrasion. 


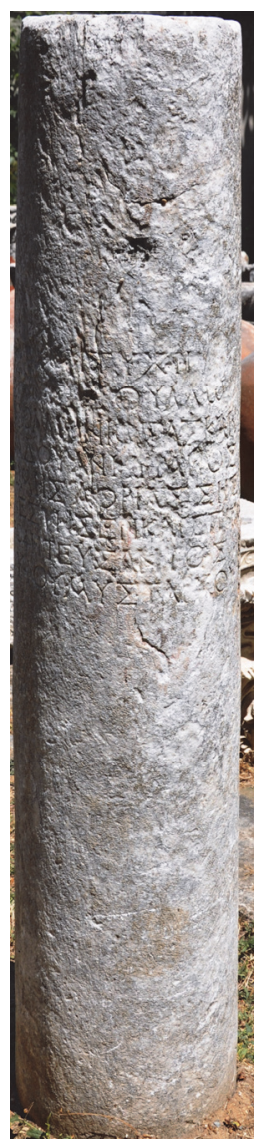

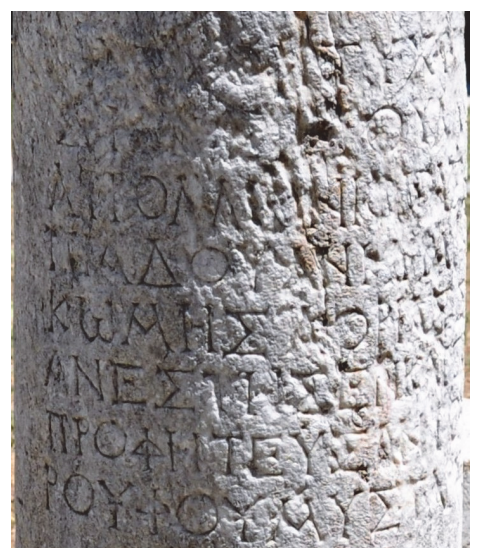

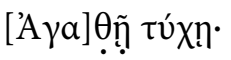

2

$$
\Delta \mathrm{l}[\mathrm{i} \mathrm{K}] \varepsilon[\rho[\rho] \sigma o u ́ \lambda \lambda \omega
$$

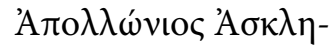

4

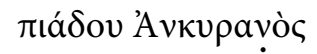

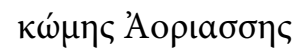

6

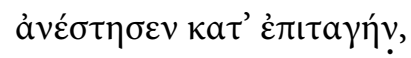

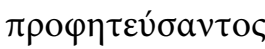

8

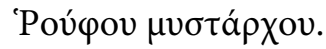

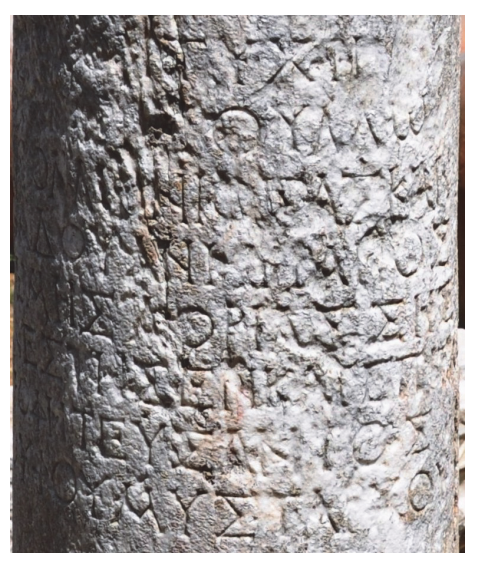

With good fortune!

Apollonios, son of Asklepiades,

a citizen of Ankyra, from the

village of Aoriasse, dedicated

(this column) to Zeus

Kersoullos, in accordance with

a command, when the mystarch

Rufus was the prophet.

L. 2: $\Delta_{\mathrm{L}}[\mathrm{i}] \mathrm{K \varepsilon} \rho[\sigma] \mathrm{ov} \lambda \lambda \omega$. Schwertheim (IHadrianoi, p. 4) is of the opinion that Zeus Kersoullos

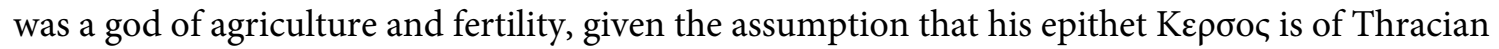
origin and means "field, farmland", yet Schwabl $(1993,334)$ is not entirely convinced by his assertion. For Ke $\rho \sigma o \varsigma$ and its meanings, see also Detschew 1957, 242; cf. also Dunst 1971. For the cult in general, see Çaçu 2005.

Zeus Kersoullos has been attested 12 times in the territory of Hadrianoi in Mysia and both the number of these inscriptions and their contents apparently reveal that the god had a sancutary there which functioned as an oracle centre (see below). These inscriptions have been discovered in the villages of Akçapınar, Belenören and Haydar situated in close proximity to each other between Orhaneli (ancient Hadrianoi) and the district of Keles. This may indicate that the sanctuary must have stood in their neighbourhood. The findspot of our inscription is unknown, but it is very probable that it has the same provenance. Apart from these, the other dedications to Zeus Kersoullos are documented in the villages of Şehriman and Derecik, ca. $70 \mathrm{~km}$ north-west of the sanctuary. In the case of the inscription recorded in the village of Dağdibi, ca. $20 \mathrm{~km}$ north of the sanctuary, it is not clear whether it is related with the cult of Zeus Kersoullos. The god is mentioned as Zeus Kersoullos Olympios in an inscription found in the territory of Aizanoi, but it is rather to be associated with the principal Zeus cult in the city because it is again closely linked with the cult in the territory of Hadrianoi, see Lehmler - Wörrle 2006, 81. The Aizanoi inscription confirms Schwertheim $(1989,253)$ who previously suggested that Zeus Kersoullos should be identified with the Zeus Olympios attested in some passages of Aelius Aristides. Cf. also Schwabl 1993, 334, fn. 14, and Battistoni - Rothenhöfer 2013, 108. All the epigraphic evidence concerning Zeus Kersoullos is given in an appendix below. 
L. 4-5: The dedicant Apollonios was apparently a citizen of Ankyra who resided in the village of Aoriasse. Till now, no information on this village is available. Given the geographical proximity, Ankyra is most likely to be identified with the city in Mysia Abbaitis, not in Galatia. A similar case can also be observed in IHadrianoi, no. 4 where a certain Attalos, a citizen of Aizanoi and resident of the village

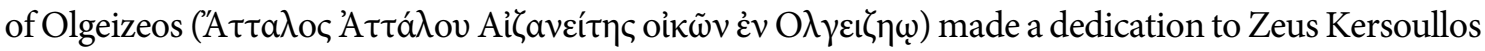
(given as Kersoussos in the inscription). Schwertheim accepted with reservation that the village of Olgeizos was located in the Aizanitis, but this has been rejected by Lehmler and Wörrle $(2006,81)$ on the grounds that the dedicant possessed the right of residence as a metoikos and they assert that the village must have been within the territory of Hadrianoi. It is less likely that this can also be applied to our case, since we don't have the 'oik $\tilde{\omega} v \dot{\varepsilon} v$ ' structure and we may therefore suggest that the village of Aoriasse was situated somewhere within the boundaries of Ankyra. The god is also attested on the coins of Kaisareia Germanike (Ripollès et al. 2015, 99) implying that the fame of this local cult surpassed Hadrianoi and extended to several places such as Ankyra, Aizanoi, and to Kaisareia Germanike.

In fact, it is not certain to which city's territory the sanctuary of Zeus Kersoullos belonged. The reason for this ambiguity lies in the fact that a Bithyniarch is attested in a fragmentary inscription dated to $146 / 7$ or 155/6 A.D. and discovered in the village of Barakl, lying approximately $10 \mathrm{~km}$ northeast of Akçapınar village, where the sanctuary is located (Battistoni - Rothenhöfer 2013,

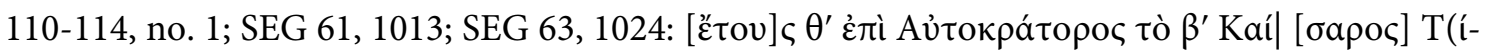

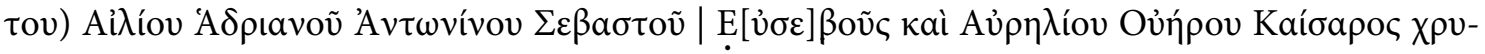

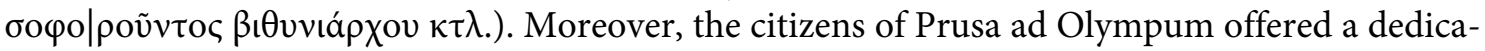
tion to Zeus Kersoullos in Tazlaktepe, a quarter of Akçapınar village (Battistoni - Rothenhöfer 2013, 128-129, no. 31 = SEG 63, no. 1026). F. Battistoni and P. Rothenhöfer hesitatingly deduced from the above mentioned evidence that Baraklı and the area around the Zeus Kersoullos sanctuary belonged to the territory of Prusa ad Olympum in Bithynia instead of Hadrianoi in Mysia, see Battistoni - Rothenhöfer 2013, 103-104. Even though T. Corsten, on the other hand, accepts that the reference to a Bithyniarch is not expected there, he doesn't agree with them, recalling the case of Aur. Mindius Mattidianus Pollio of Ephesos who served as Bithyniarch three times (I.Ephesos 627 LL. 17/18), see SEG 61, 1013 and SEG 63, 1024.

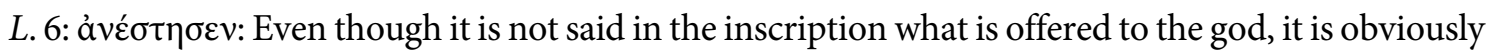

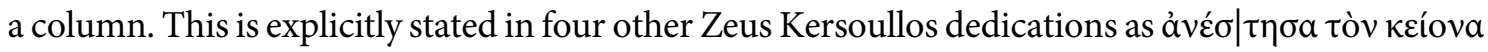

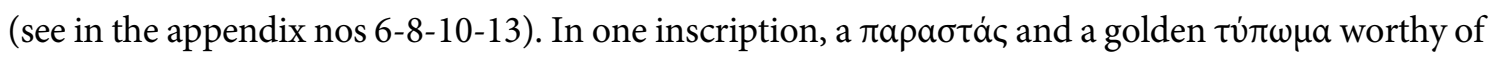
100 denaria is dedicated to the god (no. 1) as well as a $\beta \omega \mu$ ó $\varsigma$ in another (no. 3).

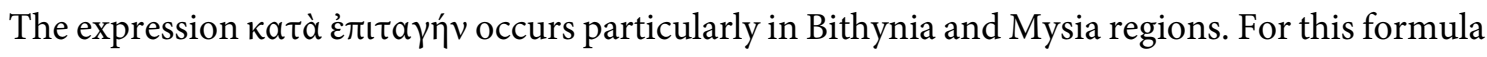
see Nock 1925, 95-98; Pleket 1981, 154 and 158.

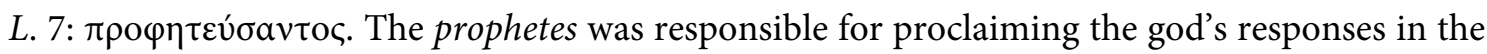
sanctuary. When its verb form $\pi \rho \circ \emptyset \eta \tau v \dot{\omega} \omega$ is used in a genitivus absolutus-construction like $\pi \rho 0-$

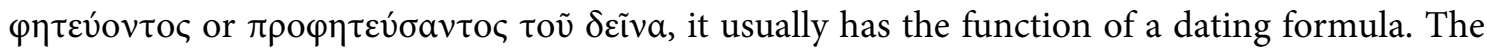
prophets attested around Hadrianoi were listed by Battistoni - Rothenhöfer 2013, 107-108. The existence of the prophets provides the most tangible evidence that we here deal with an oracular sanctuary, and this is also supported by yet another inscription discovered in the village of Ak-

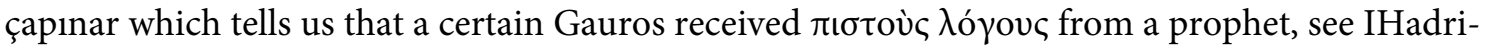

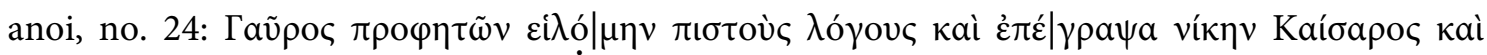

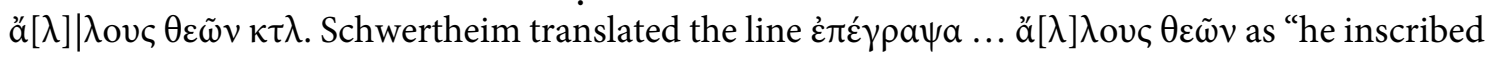


... the other (words) of the gods", and accordingly argued that the prophecy was given in this shrine not by one single (i.e. Zeus) but by various other gods. On the other hand, H. Schwabl

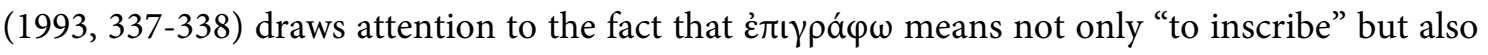

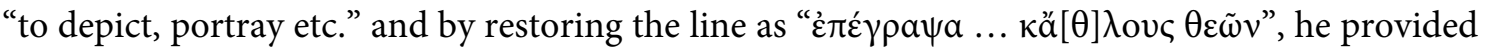
a new translation: "Gauros portrayed ... the war of the gods" and concluded that the oracular sanctuary is merely related with Zeus because this line concerns rather the Gigantomachy which resulted in the victory of Zeus. It is also confirmed by the fact that the majority of the dedicatory inscriptions found at Akçapınar and its environs are associated with Zeus Kersoullos.

The sanctuary in Hadrianoi was obviously not as famous as Didyma or Claros and it was possibly one of the local or regional oracular centres in Asia mentioned in a passage of Lucian (de dea Syria 36), see IHadrianoi, p. 22. We don't have a large number of epigraphic records regarding the office of prophetes and this term appears to be restricted mainly to Mysia, Bithynia, Phrygia, and Lydia, see Robert, OMS I, 421-422. For some examples, see SEG 59, 1416 [Apollonia ad Rhyndacum]; IKalchedon, nos. 7, 19, 42, 61; TAM V,1, 535 [Maionia]; TAM V,2, 1411 [Magnesia ad Sipylum]; ILaodikeia am Lykos, no. 67; MAMA IX, 60 [Aizanitis]; Onur 2011, 337-338.

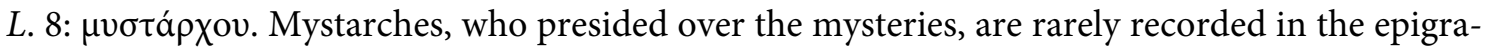
phical evidence. Most of the occurences in Asia Minor are from Kyzikos, a city lying not so far from the area in question, see e.g. CIG II 2, 3662; 3663A. As far as we know, there are only two examples apart from Kyzikos, see IPrusa ad Olympum I, no. 52; IKlaudiu Polis, no. 65. While one of its equivalents $\mu v \sigma \tau \eta \rho$ ó $\rho \chi \eta \varsigma$ is attested only in Kyzikos and Nikomedia (see CIG II 2, 3666

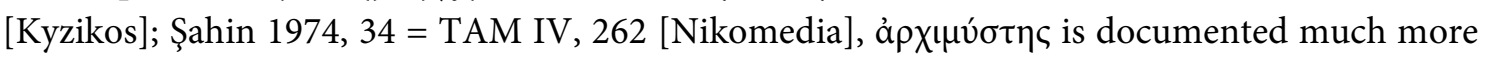
frequently and over a much wider geography, see Waldmann 1978, 1309-1315. It is striking that Rufus served both as a prophet and a mystarch at the same time. Rufus is named without a patronymic.

Date: Roman Imperial Period

\section{Appendix: Documents relating to Zeus Kersoullos}

1. IHadrianoi, no. 1 (second half of the $1^{\text {st }}$ cent. A.D.)

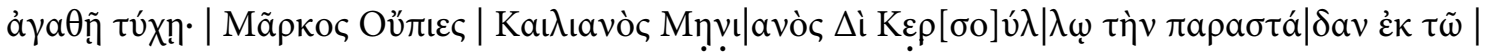

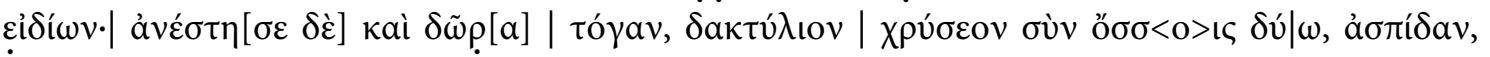

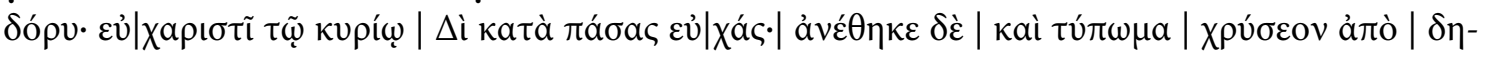
vapíwv| Ékatóv.

2. IHadrianoi, no. 2 (2 $2^{\text {nd }}$ cent. A.D. $)$

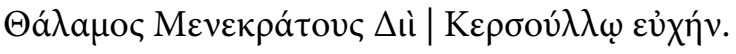

3. IHadrianoi, no. 3 = Battistoni - Rothenhöfer 2013, 122-123, no. $17=$ SEG 63, no. $1027\left(2^{\text {nd }}\right.$ cent. A.D.)

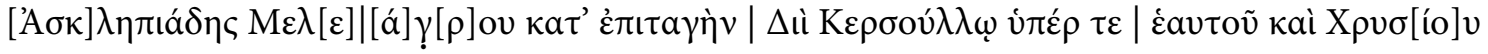

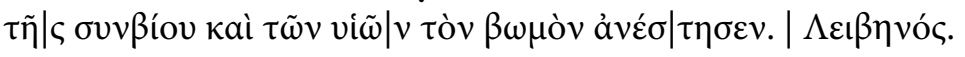

4. IHadrianoi, no. 4 ( $2^{\text {nd }}$ cent. A.D.)

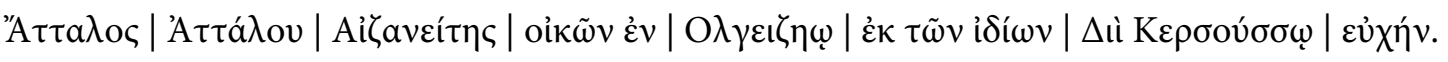

5. IHadrianoi, no. 5 ( $1^{\text {st }}$ cent. A.D. $)$ 


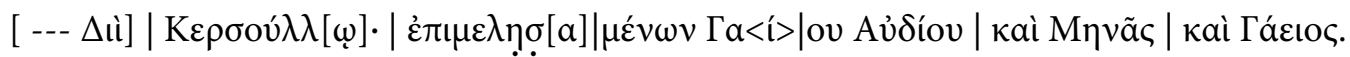

6. IHadrianoi, no. 6 ( $2^{\text {nd }}$ cent. A.D. $)$

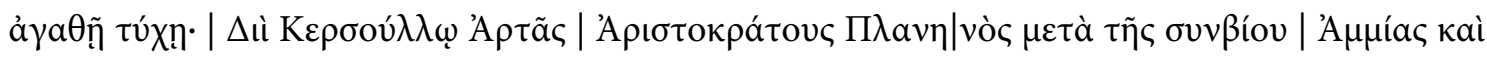

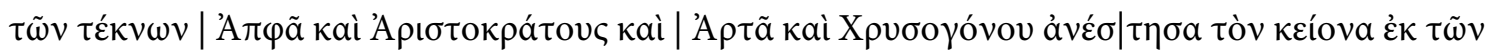

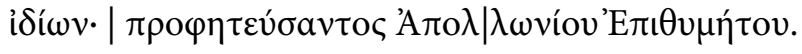

7. IHadrianoi, no. 7 ( $2^{\text {nd }}-3^{\text {rd }}$ cent. A.D. $)$

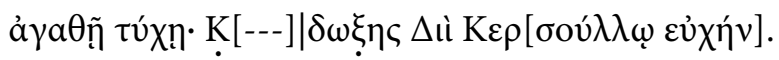

8. IHadrianoi, no. 8 ( $3^{\text {rd }}$ cent. A.D.)

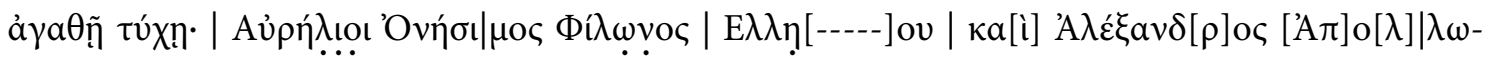

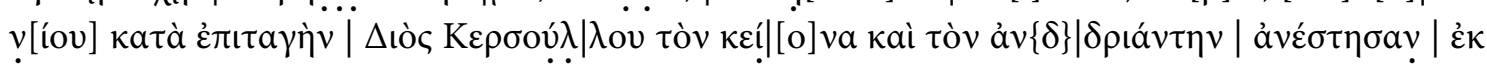
$\tau \tilde{\omega} v i \delta i ́ \omega v$.

9. Battistoni - Rothenhöfer 2013,129, no. $32=$ SEG 63, no. 1031 ( $2^{\text {nd }}-3^{\text {rd }}$ cent. A.D. $)$

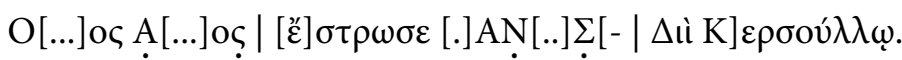

10. Battistoni - Rothenhöfer 2013, 128-129, no. $31=$ SEG 63, no. $1026=$ AE 2013, no. 1467 (113/114 A.D.)

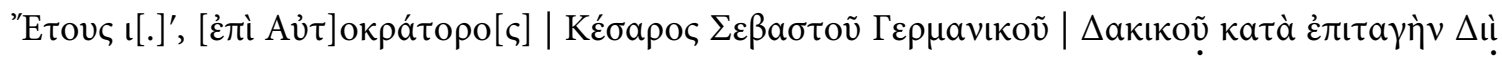

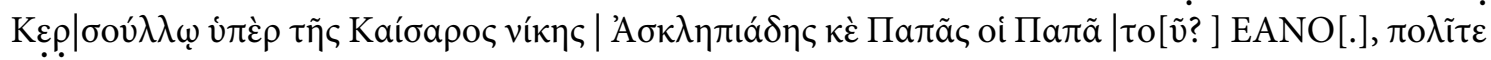

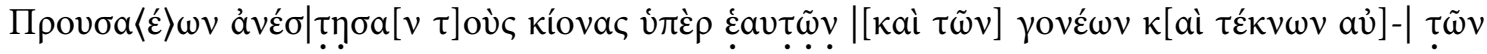

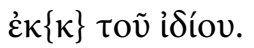

11. Battistoni - Rothenhöfer 2013,124 , no. $19=$ SEG 63, no. 1029 ( $2^{\text {nd }}-3^{\text {rd }}$ cent. A.D. $)$

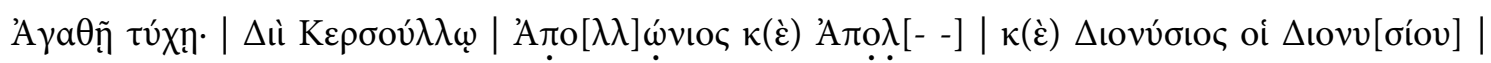

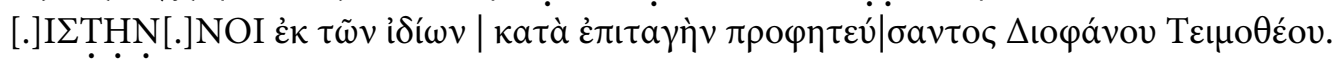

12. Battistoni - Rothenhöfer 2013, 124-125, no. $20=$ SEG 63, no. 1030; AE 2013, no. $466\left(2^{\text {nd }}-3^{\text {rd }}\right.$ cent. A.D.)

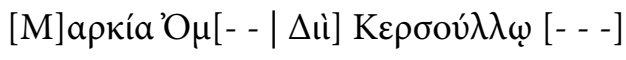

13. Battistoni - Rothenhöfer 2013, 123-124, no. $18=$ SEG 63, no. 1028 ( $\left.2^{\text {nd }}-3^{\text {rd }} c e n t . ~ A . D.\right)$

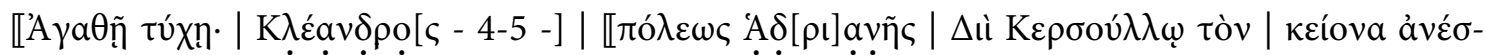

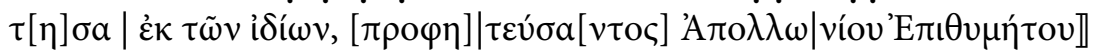

14. Akyürek Şahin 2010, 273-274 = Jones 2012, 233-236 = SEG 59, no. 1418 ( $2^{\text {nd }}-3^{\text {rd }}$ cent. A.D. $)$

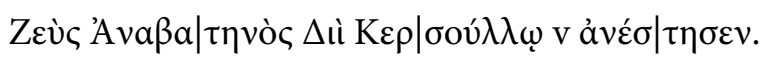

15. IHadrianoi, no. 21 (?)

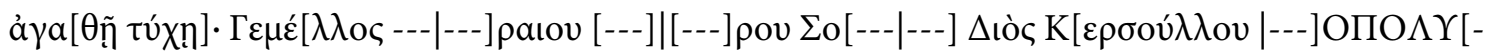

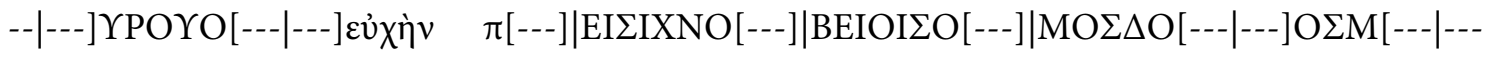
]TY[--- $]$

16. Lehmler - Wörrle 2006, 79-82 no. 137 = SEG 56, no. 1436 (Aizanoi-Early Imperial Period). 


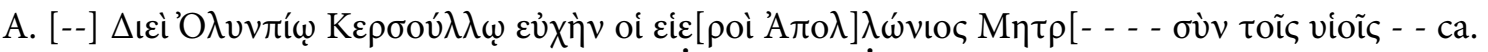

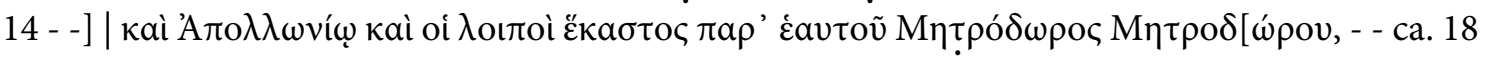

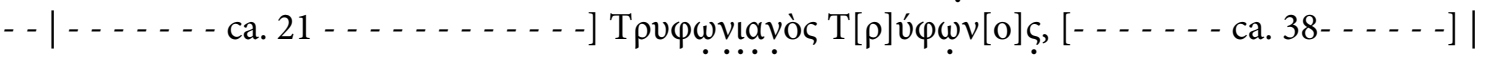

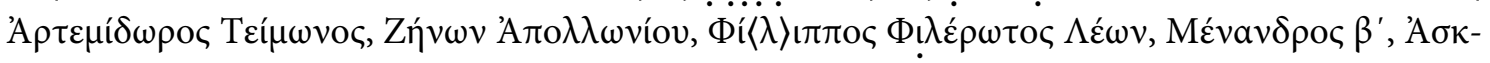
$\lambda \eta \pi i a ́ \delta \eta \varsigma$ Tрофí́pov.

Cf. also IHadrianoi, no. 36 ; SGO II, no. 08/08/03 ( $2^{\text {nd }}-3^{\text {rd }}$ cent. A.D. $)$

\section{Dedication to a God (Zeus Kersoullos?)}

Marble block stone; no inventory number yet given; findspot unknown. Dimensions: $\mathrm{H} .: 106 \mathrm{~cm}$; W.: $66 \mathrm{~cm}$; D.: $23 \mathrm{~cm}$; Lh.: 1,3-3,5 cm.

Carved block with a thick frame. Broken at the right. The profile presumably continued on the broken missing part. Damaged in all parts, in particular on the moulding. A Greek inscription of six lines is carved in the upper part of the framed area. The inscription is carelessly carved but intact.
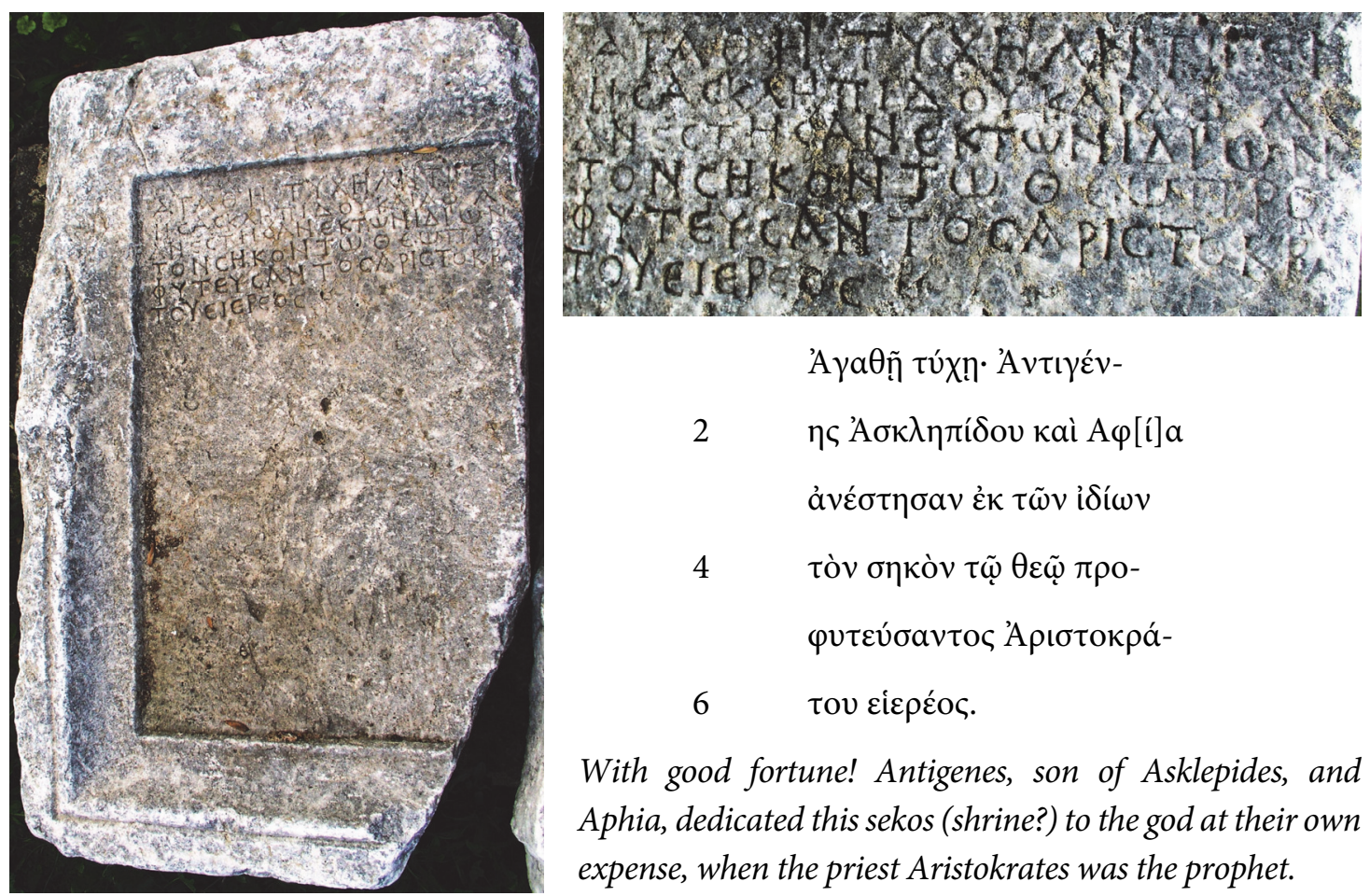

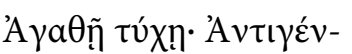

$2 \quad \eta \varsigma$ 'А

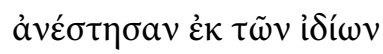

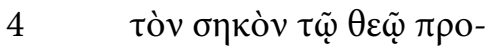

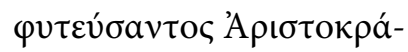

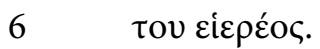

With good fortune! Antigenes, son of Asklepides, and Aphia, dedicated this sekos (shrine?) to the god at their own expense, when the priest Aristokrates was the prophet.

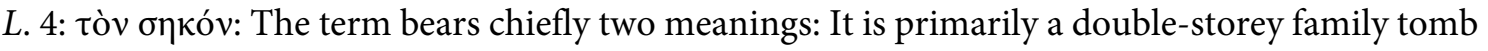
(see Kubińska 1968, 114-116; Mitchell 1977, 90), but it also designates a sacred enclosure, shrine or a cella, see LSJ, s.v.; Ginouvès 1998, 39, who claims that this word means only the cella/naos and not the whole temple.

The authors Pollux and Ammonius explain the distinction between naos and sekos in a way that the former pertains to the gods, while the latter is employed for the heros, see Pollux, Onom. I. 6:

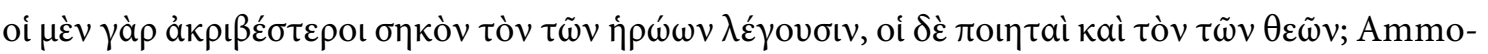

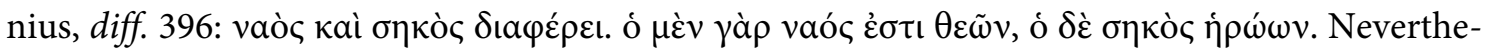
less, it is beyond any doubt that according to the wording of this inscription the sekos is dedicated to a god. As already emphasized above, many dedications to Zeus Kersoullos in this area manifest 
evidence of the existence of the god's sanctuary. Furthermore, Battistoni and Rothenhöfer argued that there must have been another shrine of an unknown god around Baraklı village, apart from that of Zeus Kersoullos in Akçapınar village and its surroundings. That we don't know the actual findspot of this artefact and that the god's name is not clearly expressed in the inscription poses a difficulty to us in determining to which sanctuary this term related.

For the occurrences of the term in Asia Minor relating to a sanctuary, see Mitchell 1977, 89-90, no. 31 = SEG 27, 851 [Ankyra]; ISmyrna II.1, no. 726.

$\tau \tilde{\omega} \theta \varepsilon \tilde{\omega}$. It presumably meant Zeus (Kersoullos), the dominant god worshipped in the region (see above). However, the fact that some other male deities such as Dionysos and Apollon are also attested and that there is no iconographic element on the artefact prevents us from claiming anything with certainty concerning the identity of the god, see IHadrianoi, no. 12; Battistoni - Rothenhöfer 2013, 122, no. 16. For instance, ì $\theta \varepsilon$ có in Ihadrianoi, no. 16 could have been securely identified with Hygiea due to the snake figures carved below the inscribed field. Cf. a similar case in Battistoni - Rothenhöfer 2013, 119-120, no. 12.

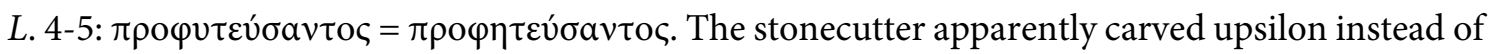
eta. For the office of prophetes, cf. above. It is a strong indication that this stone was also brought to the museum from the same area.

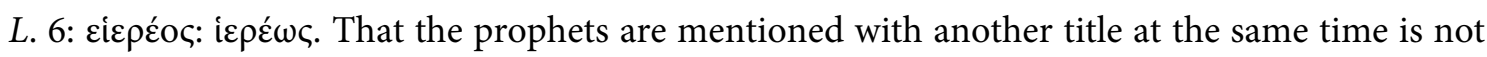
prevalent and seemingly attested only above no. 2 (as mystarches) and here as priest. In Didyma, for example, the cult was headed by a prophet, never by a hiereus, contrary to Delphi, where the cultic inscriptions always refer to a hiereus, see Fontenrose 1988, 46. For the priests who are also called prophets, cf. Callan 2010, 40.

Date: Roman Imperial Period

3a. Marble bomos. Copied in the village of Baraklı, Keles/Bursa in 2006 by Mr. Ayhan Çaçu who is working as a school teacher there. We haven't seen the insciption itself but deciphered it from the hand-copy and the photos taken by Çaçu. We thank him very much for sharing the inscription with us. The current whereabouts of the bomos remains unknown.

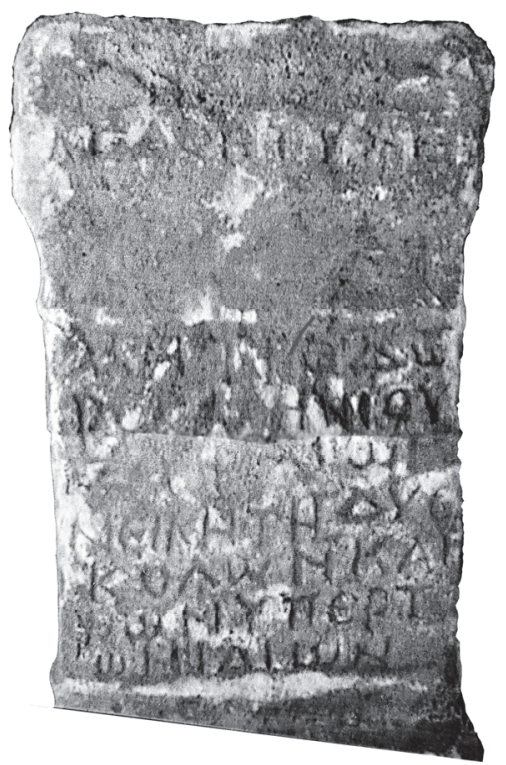

\begin{tabular}{|c|c|}
\hline \multirow{3}{*}{2} & 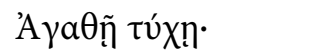 \\
\hline & 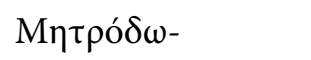 \\
\hline & pos Mqvíou \\
\hline \multirow[t]{2}{*}{4} & Ev̉paíwv \\
\hline & 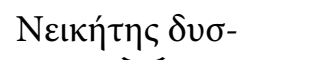 \\
\hline \multirow[t]{2}{*}{6} & 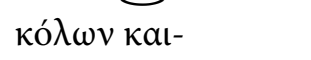 \\
\hline & $\rho \tilde{\omega} v$ v́t $\grave{\varepsilon}_{\rho} \tau-$ \\
\hline \multirow[t]{2}{*}{8} & $\tilde{\omega} v i \delta i ́ \omega v$ \\
\hline & {$[-\ldots-\ldots]$} \\
\hline \multirow[t]{3}{*}{10} & $\varepsilon \dot{\chi} \chi \eta ́ v, \pi \rho \circ \varphi-$ \\
\hline & $\eta \tau \varepsilon v ́ \sigma \alpha v \tau o \varsigma \mathrm{T}-$ - - ] \\
\hline & $-\ldots$ \\
\hline
\end{tabular}

With good fortune!

Metrodoros, son of Menios

(and) Euraion Neiketes

(dedicated this to?)

in fulfillment of a vow

due to? the unpleasent times

for the sake of their own

(family members)

when N.N., son of T...

was the prophet. 
L. 4: Ev̉paí $\omega v$ has to date never been attested, but we cannot be sure if this reading is accurate because the first letters are extremely dubious. If we preferred beta, for example, instead of a rho, we would then have the name Eubaion, which has indeed few occurrences (albeit geographically distant), see LGPN I, 171 s.v. and II, 163 s.v.

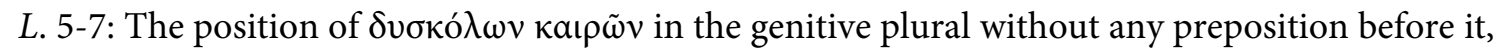
is bizarre. Epigraphically, this expresion is rare and not attested in any dedicatory context. It only

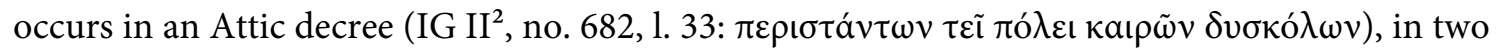

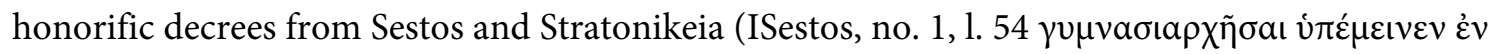

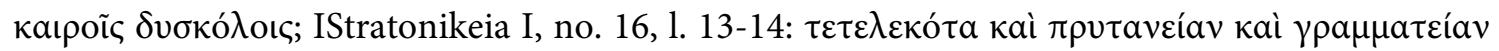

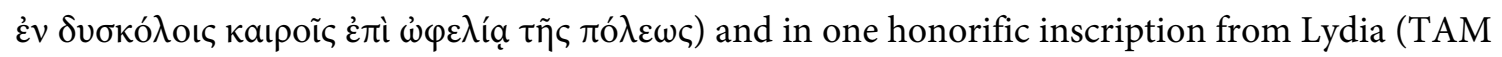

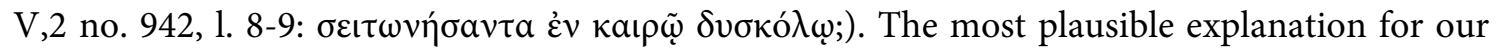
case is that the dedicants were probably farmers and after having been affected negatively by the meteorological conditions (drought or conversely flood/hail), they made this vow to the god. Yet again we don't know whether it was offered to Zeus Kersoullos who is thought to be a god of fertility and agriculture (see above no. 2), but if our interpretation were correct, this would be a strong possibility.

L. 9: In the copy of Çacu, there is a space in line 9. We couldn't read anything on the photo, but it is highly possible that the name of the god must have stood there in the dative case.

Date: Roman Imperial Period

\section{Dedication to a God}

A marble altar fragment; kept in the garden of the Bursa Museum. No inventory number yet given. Findspot: Zindan Kapısı in Bursa. Dimensions: H: 35 cm; W: 31 cm; D: 23,5 cm; Lh.: missing.

The altar is broken at the top and below. Crown and base are missing. Shaft also broken into two parts and heavily damaged. An inscription of seven lines is neatly carved.

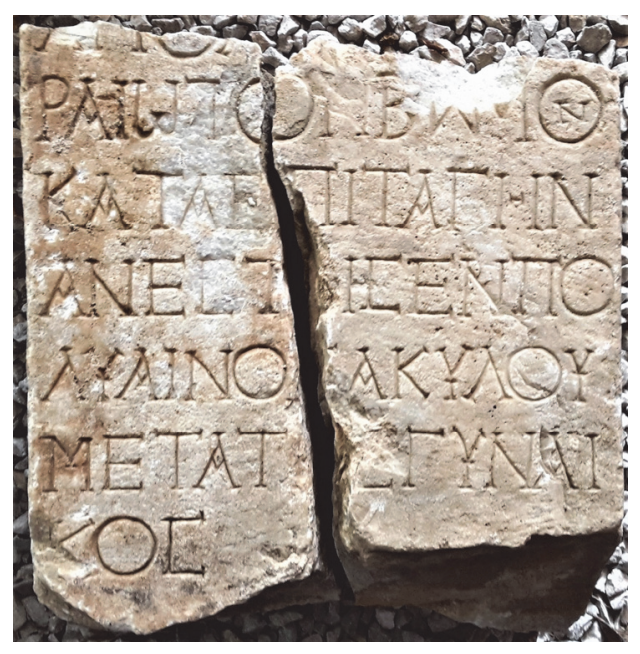

Åoㅅㅅㅡ $[\lambda \omega v \imath ? .]-$.

2

4 paíw tòv $\beta \underbrace{\omega \mu o ̀ v}$

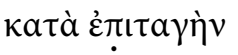

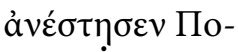

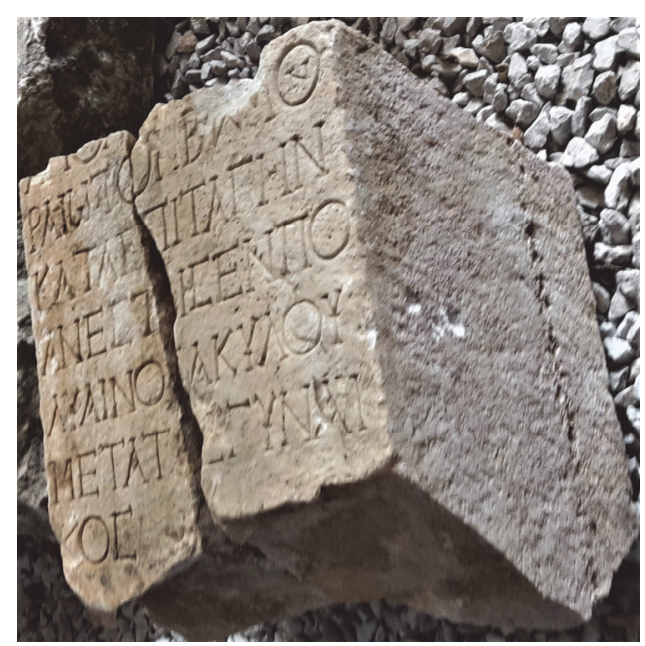

Polyainos,

son of Akylas,

together with his wife

dedicated this bomos 


\begin{tabular}{|c|c|c|}
\hline & 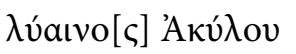 & on (divine) command, \\
\hline 6 & $\mu \varepsilon \tau \grave{\alpha} \tau[\tilde{\eta}] \varsigma \gamma v v \alpha \mathrm{l}-$ & to Apollon? . raios. \\
\hline
\end{tabular}

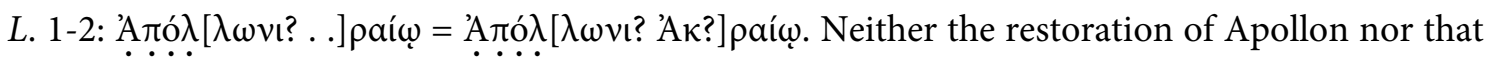
of his epithet Akraios is certain, but if it were the case, this would be the first document in which Apollon is attested with the epithet of Akraios. Akraios is mainly related with Zeus, but the third letter in the first line, i.e. an omicron, doesn't let us make a reconstruction as $\Delta$ ì Aкpaí as we could determine, Akraios was also applied to Men once, see Drew-Bear 1978, 31, no. 5. One can also suggest the epithet Agoraios, which is not infrequently attested for Zeus, as well as for other deities such as Dionysos and Hermes.

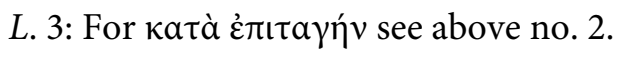

Date: Roman Imperial Period

\section{Funerary Inscriptions}

\section{Funerary inscription of Ekgle(k)tos?}

A marble sarcophagus with grey veins. Kept in the garden of the museum. No inventory number yet given. Unearthed in the course of highway construction at Çaylı/Nilüfer. Dimensions: H.: 77 cm; W.: $237 \mathrm{~cm}$; D.: $21 \mathrm{~cm}$; Lh.: $2,5 \mathrm{~cm}$.

Only the facade of this half-fabricated garland sarcophagus is preserved, unfortunately the rest is missing. In the middle of the chest there is a rectangular tabula ansata containing an inscription of four lines.
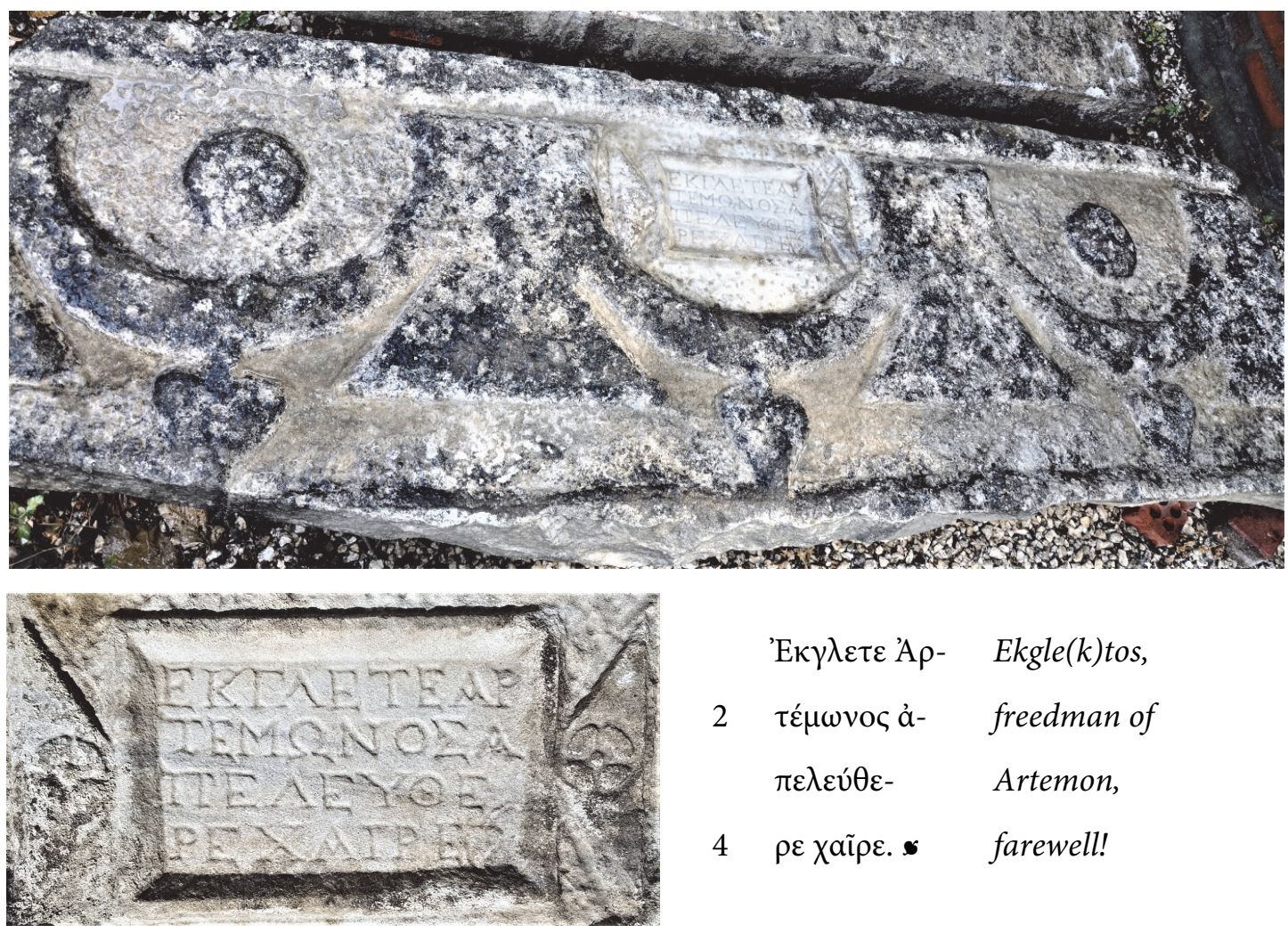

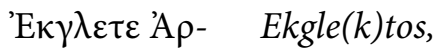

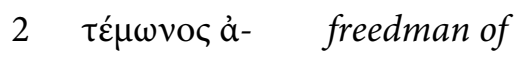
$\pi \varepsilon \lambda \varepsilon v ́ \theta \varepsilon-\quad$ Artemon,

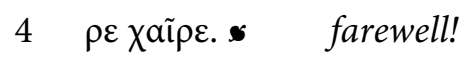




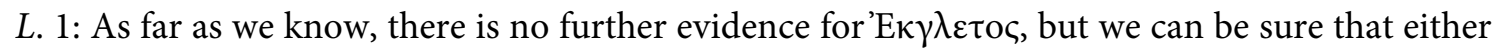

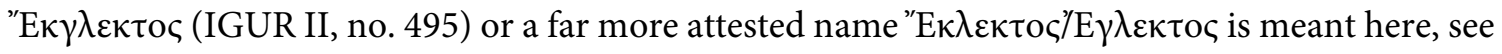
LGPN VA, 132 s.v.; Anderson et al. 1910, 194 (for”Е $\gamma \lambda \varepsilon \kappa \tau$ ()). Cf. below no. 24 where the deceased is mentioned also in the vocative case.

This is yet another example for the Proconnesian half-fabricated garland sarcophagus which was quite prevalent in Asia Minor in the $2^{\text {nd }}$ and $3^{\text {rd }}$ centuries A.D., see Asgari 1977 and Koch - Sichtermann 1982, 484-497. For a similar sarcophagus discovered in Mudanya (Apameia Myrleia in Bithynia) which today is also kept in the garden of the Bursa Museum, see IApameia-Pylai, 37 no. 27 A pl. 1.

Date: Roman Imperial Period

\section{Funerary bomos of Asklepiodote}

Marble bomos. Kept in the garden of the museum. No inventory number yet given. Unearthed in the course of Buski (Bursa Water and Sewage Administration) works in İnegöl (Çitli). Dimensions: H.: $132 \mathrm{~cm}$; W.: $63 \mathrm{~cm}$ (crown); 48-52 cm (shaft); 71-72 cm (base); D.: $53 \mathrm{~cm}$ (crown); 43$44 \mathrm{~cm}$ (shaft); $55 \mathrm{~cm}$ (base); Lh.: 3-4 cm.

The bomos is defaced at the top and has small breaks. On the sides of the shaft some breaks are also visible. Upper moulding decorated with corner acroteria. Low base undecorated. A carelessly carved inscription of four lines begins from the moulding.
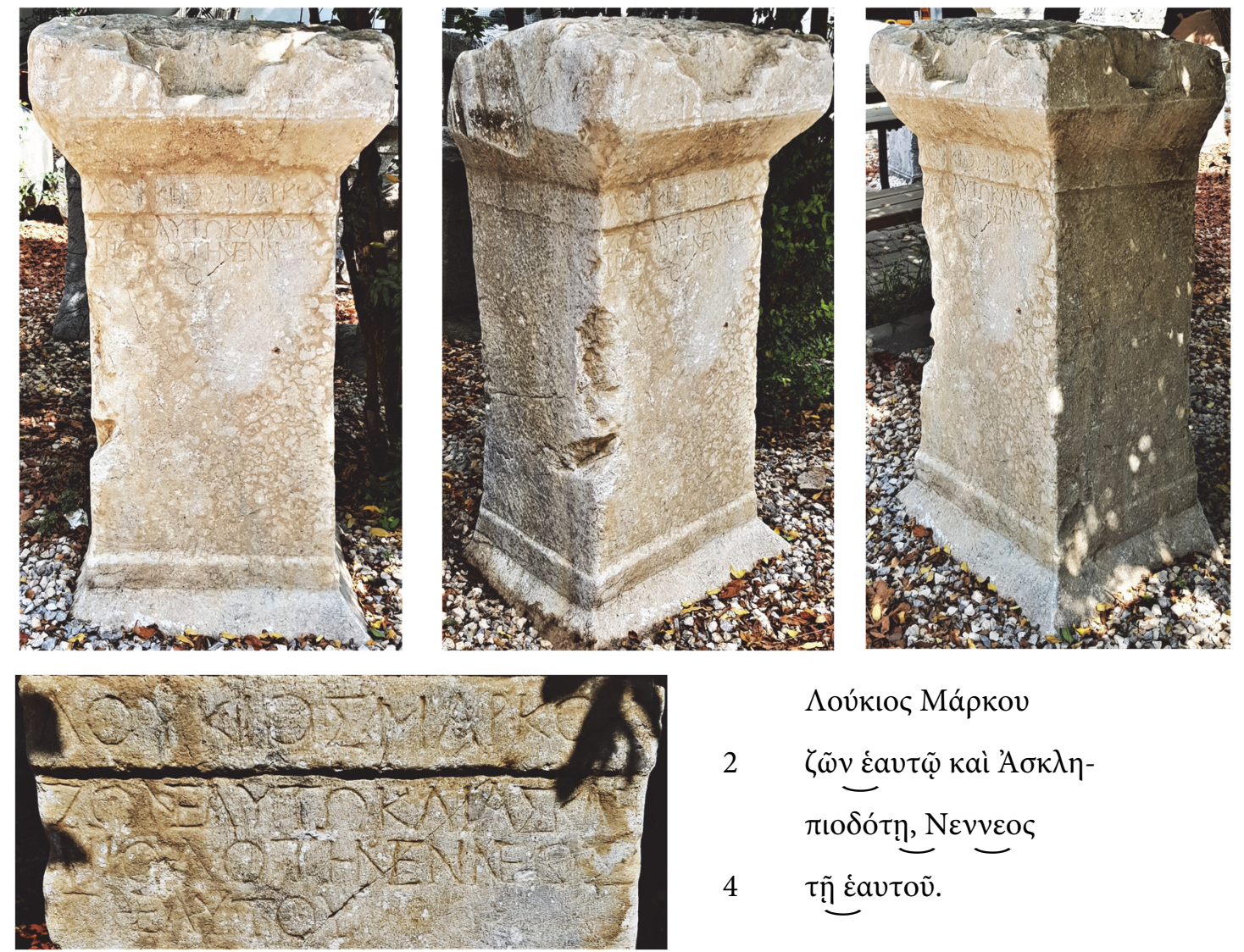

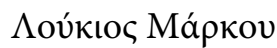

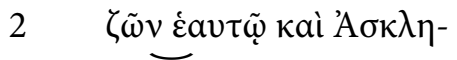

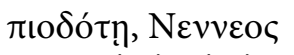

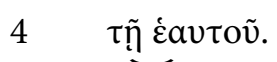

Lucius, son of Marcus, (constructed this bomos) in his lifetime, for himself and for Asklepiodote, daughter of Nennis, his own (wife). 
L. 3: Nevveoc. Nennis (gen. Nennios) is attested once in Cilicia, see Dagron - Feissel 1987, no. 11 A 2, 1. 40 = LGPN VB, 312 s.v. In this inscription । appears as $\varepsilon$, cf. Brixhe 1987, 51: „Les inscriptions anatoliennes fournissent bon nombre d'échanges entre $E(A I)$ et $I(E I, H, Y)$ devant /a, o, u, e/."

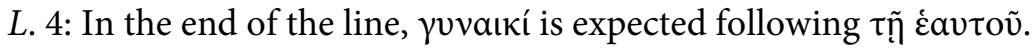

Date: Roman Imperial Period

\section{Funerary bomos of Eutychides}

Marble bomos. Placed in the garden of the museum. No inventory number yet given. Findspot unknown. Confiscated by the police from smugglers near Söğüt Mah., Orhaneli/Bursa. Dimensions: $\mathrm{H}: 84 \mathrm{~cm}$; W: $37,5 \mathrm{~cm}$; D: $30 \mathrm{~cm}$; Lh: 2,5-3 cm.

Except for some small damages, the altar is generally well-preserved. It has a low base and crown. On the upper front face there is an inscription of five lines. Guidelines applied to prevent the lines from becoming uneven are visible. Beneath the inscription the high relief of a large wreath.
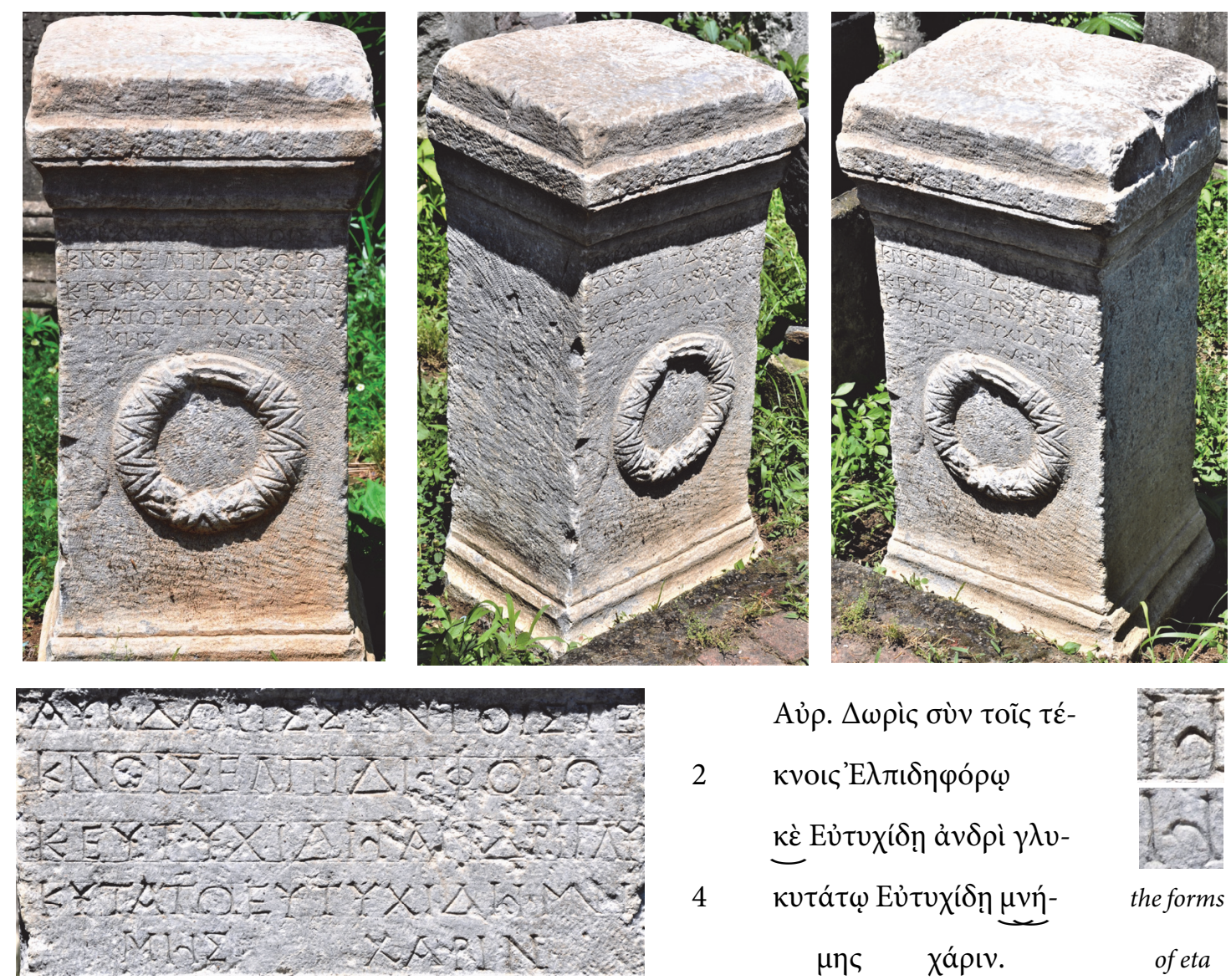

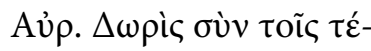

$$
\begin{aligned}
& 2
\end{aligned}
$$

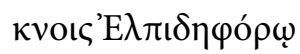

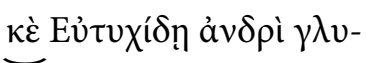

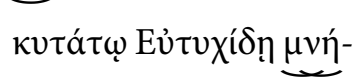

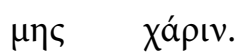

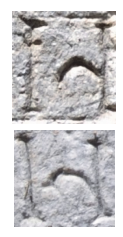

the forms

of eta

Aur(elia) Doris (constructed this altar) with her children Elpidephoros and Eutychides to her sweetest husband Eutychides, in memory.

L. 1: Apart from this inscription, the name of $\Delta \omega$ pí occurs only once in Bithynia and Mysia, see Şahin - Onur 2010, 35-36, no. 10. In Greek mythology, she was the mother of the sea nymphs known as the Nereids. For the name, cf. also Brixhe 1991, 20.

L. 2:' $\mathrm{E} \lambda \pi \_\delta \eta \varphi$ ó $\rho \omega$. For the name, see LGPN VA, 154 s.v. It is also documented in a funerary inscription found in Balıkesir, see Tanriver 2013, 54 no. 50. 


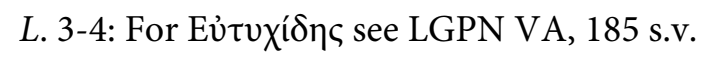

Date: After 212 A.D. (Constitutio Antoniniana).

\section{Funerary Inscription of Chreste}

Marble altar fragment. Kept in the garden of the museum. No inventory number yet given. Findspot: Harmancik/Bursa. Dimensions: H: 83 cm; W.: 45-52 cm; D.: 38 cm; Lh.: 2-2,5 cm.

Broken at the top and below. The remaining shaft is also broken into two pieces in the middle. Base missing. The crown is heavily damaged. The inscription of four lines carved on the shaft is hardly legible in the broken parts. Below the inscription there are some figures in relief depicting objects possibly of a woman but they cannot be certainly identified due to their defaced surfaces, except for the circular object, most probably a mirror with a handle.
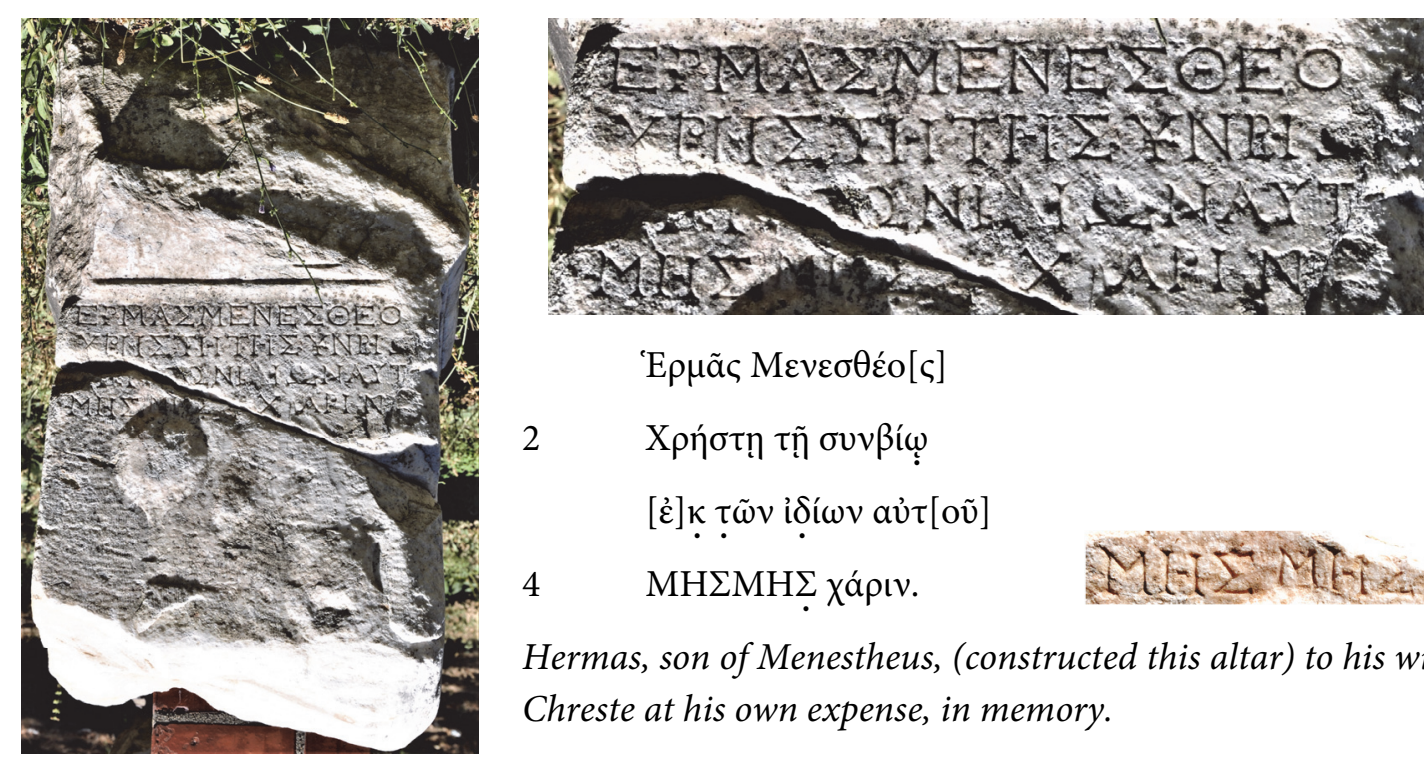

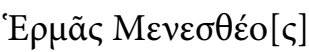

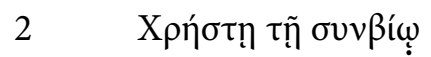

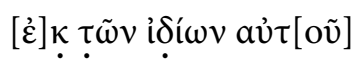

$4 \quad \mathrm{MH} \Sigma \mathrm{MH} \Sigma \chi \alpha \dot{\rho} \rho$ เv.

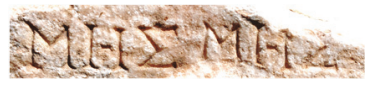

Hermas, son of Menestheus, (constructed this altar) to his wife Chreste at his own expense, in memory.

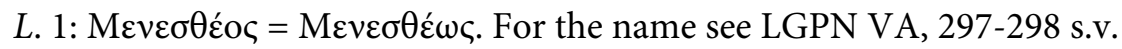

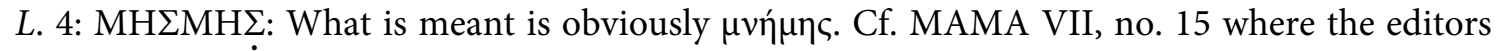
write in minuscule transcription $\mu \eta \dot{\sigma} \sigma \mu \eta$ s and state that the form may be $\mu v \dot{\eta} \mu \eta$ s.

For a similiar altar both in terms of its typology and the objects sculpted, see IHadrianoi, 101 no. 152 pl. 25.

Date: Roman Imperial Period

\section{Funerary Inscription}

Altar of white marble, now in the garden of the museum. Inv. no: 2009/159. Findspot: Yazıbaş1 village/Keles/Bursa. Dimensions: H.: $71 \mathrm{~cm}$; W.: $37 \mathrm{~cm}$; D.: $32,5 \mathrm{~cm}$; Lh.: $3 \mathrm{~cm}$.

The altar is cut on all sides and corners, possibly for making it suitable for a secondary use. Both the crown and the base are chiseled away and do not longer exist. Thereby, the inscription was damaged at the top and on both sides. 

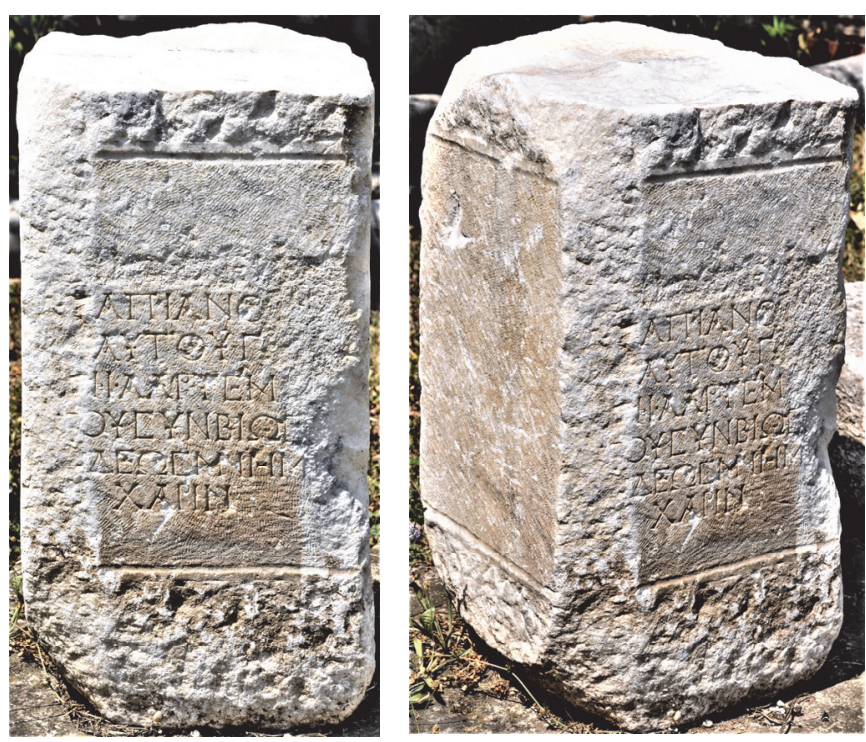

$$
\begin{aligned}
& \text { [3-4].O. } \Lambda \mathrm{EI}[3-4] \\
& 2 \text { [. .] Пุ } \\
& \text { [...] aủนoี̃ } \gamma \underline{[}[v .] \\
& 4 \text { [...]I·I·A А } \rho \tau \varepsilon \mu[. .]
\end{aligned}
$$

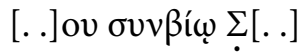

$$
\begin{aligned}
& 6[\ldots] \delta \varepsilon \omega \varsigma \mu \nu \eta \dot{\mu} \mu[\eta \varsigma] \\
& \text { xápıv. }
\end{aligned}
$$

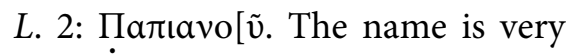
likely Палıаvóc.

L. 4: [. . .]I-I·A. Possibly a woman's name ending in -a stood in this line.

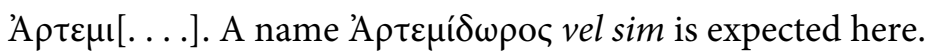

Date: Roman Imperial Period

\section{Funerary bomos of Aurelius Stachys, his wife Secunda and their children}

A cylindrical bomos of marble; placed in the garden of the museum. Inv. no: 2016/24. Findspot: Gemlik (Kios)/Bursa. Dimensions: H.: 91-93,5 cm; Diameter: 57 cm; Lh.: 3-4 cm.

The bomos has mouldings on the crown and one moulding on the base. The base is partly broken. The monument is quite abraded and shows many cracks. An inscription of nine lines is carved on the shaft.
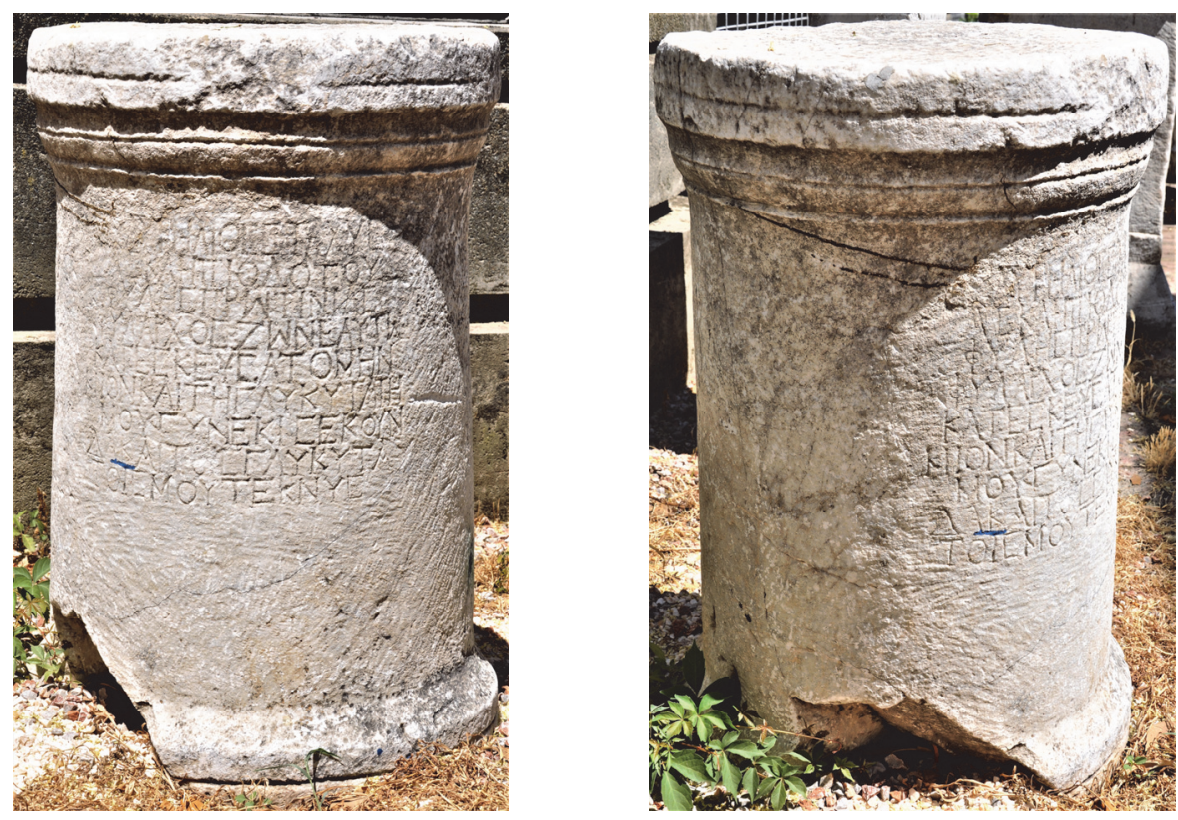


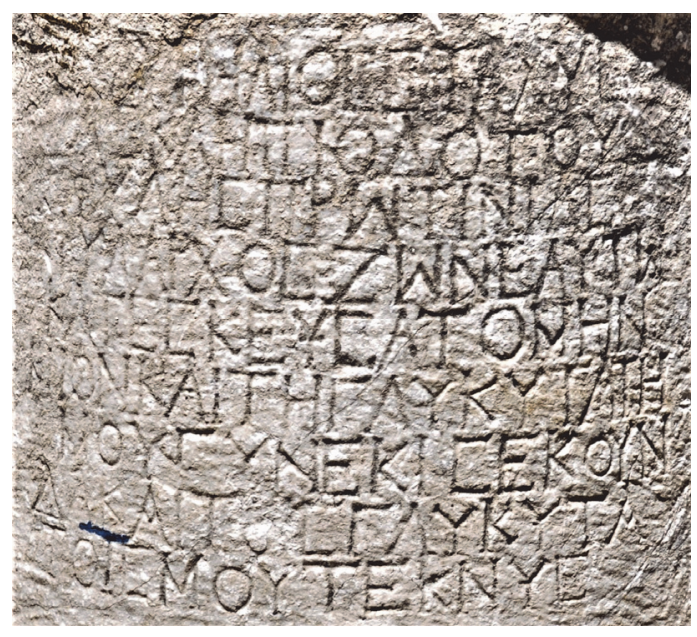

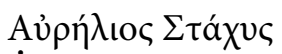

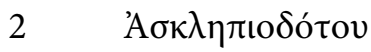

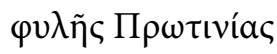 \\ 4

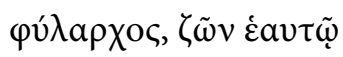

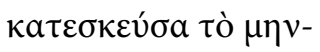

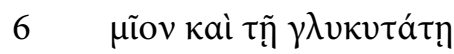

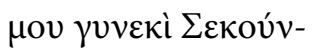

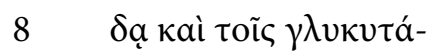

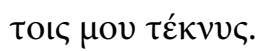

I, Aurelius Stachys, son of Asklepiodotos, the phylarch of the phyle of Protinia, constructed (this funerary bomos) during lifetime for myself and for my sweetest wife Secunda and for my sweetest children.

L. 1: For $\Sigma \tau$ đ́́ $\chi \cup \varsigma$ see LGPN VA, 409 s.v. Till now this name appears not to have been attested in Bithynia.

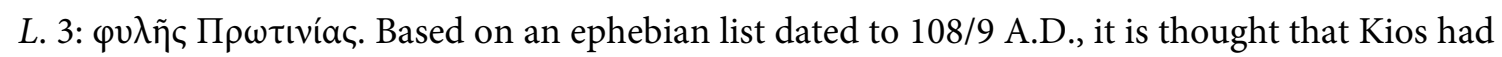
at least 10 phylai, see IKios, no. 16. See also Kunnert 2012, 80-81. However, so far we know only

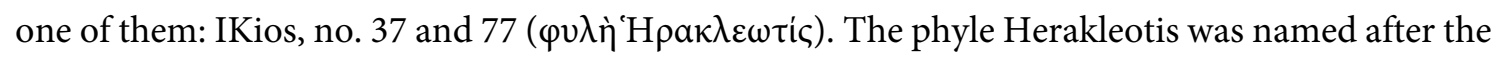
mythical founder of the city, Herakles. With this new inscription, the number of the phylai documented increased to two. We don't have any knowledge regarding this phyle, and what the word or name Protinia signifies remains unknown.

L. 4: For the office of $\varphi v ́ \lambda a \rho \chi \circ \varsigma$ see Kunnert 2012, 261-267. Stachys used instead of the grammatically required $\dot{\varepsilon} \mu a v \tau \tilde{\omega}$ the form for the third person, $\dot{\varepsilon} \alpha v \tau \tilde{\omega}$.

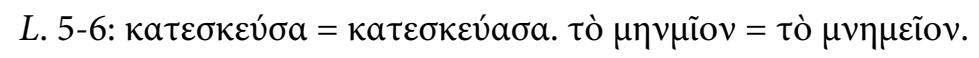

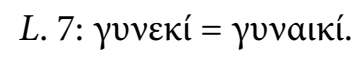

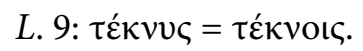

Date: After 212 A.D. (Constitutio Antoniniana)

\title{
11. Posthumous honorary inscription of Fabia Fabula
}

Cylindrical column of white marbe, now in the garden of the museum. Till now no inventory number was given to it. Findspot unknown. Dimensions: H.: $68 \mathrm{~cm}$; Diameter: $43 \mathrm{~cm}$; Lh.: 2,5-4 $\mathrm{cm}$.

The column is evenly cut off at the top and below. No crown or base is preserved. An inscription of six lines is carved on the shaft. 

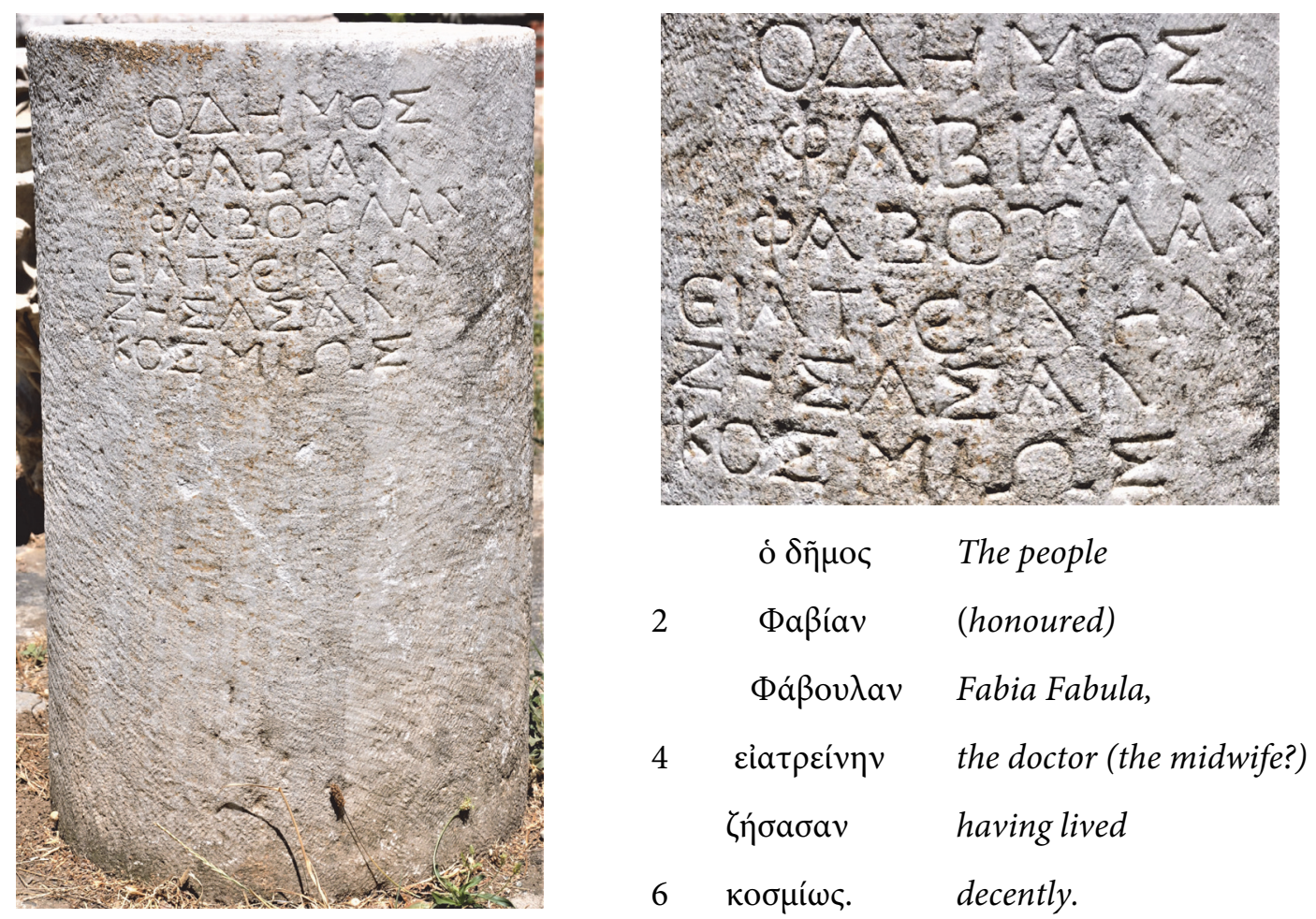

L. 1: For other posthumous honors paid to the deceased in Prusa ad Olympum, see IPrusa ad Olympum I, nos. 26-31.

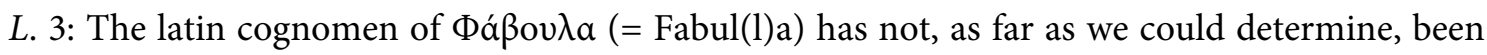
recorded in Asia Minor to date. Yet, both Fabulla and its female version prevail in the western Roman Empire, see Kajanto 1965, 170. Cf. Schulze 1991, 176, 461. At the end of the line, it seems that the stonemason carved a sigma at first and then converted it to a ny.

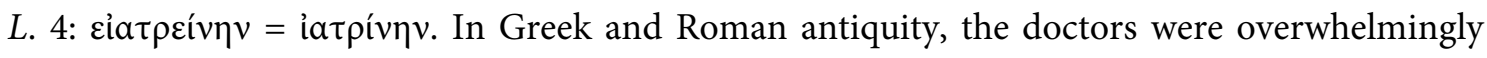
male, but there were, though rarely, also female doctors. It is commonly thought that they were mostly confined to the speciality of obstetrics and gynecology, but we simply don't have enough sources to determine if they were also active in any other medical field, see Samama 2003, 15-16. For other female doctors attested in Asia Minor see Samama 2003, nos. 188 (Pergamon); 280 (Tlos); 304 (Kios); 320 (Ankyra); 324 (Neoclaudiopolis); 329 (Adada); 342 (Lycaonia); 354 (Seleucia ad Calycadnum); 358 (Korykos); İplikçioğlu et al. 2007, no. 32 = SEG 57, 1486 (Termessos). For a useful study that evaluates all the Latin and ancient Greek epigraphic and literary evidence for female doctors, see Cilliers - Retief 1999, 47-65. See also Flemming 2007, 257-259; Laes 2011,

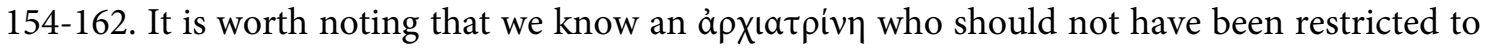
birth assistance, cf. Robert 1964, 177.

L. 6: коб $\mu$ í $\omega \varsigma$ is frequently seen in the funerary inscriptions of Prusa ad Olympum, see IPrusa ad Olympum I, p. 75; Uzunoğlu 2015, 405.

Date: Roman Imperial Period

\section{Funerary inscription of Maxima}

Altar-like stele of whitish marble. Kept in the garden of the museum. No inventory number yet given. Findspot unknown. Dimensions: H.: 90 cm; W.: 30 cm; D.: 15 cm; Lh.: 1-1,3 cm. 
The crown of the altar-like stele is decorated with high corner acroteria. A horizontal moulding is seen above the crown and its upper part is partly broken. A carefully carved inscription of seven line is on the shaft of the stele.
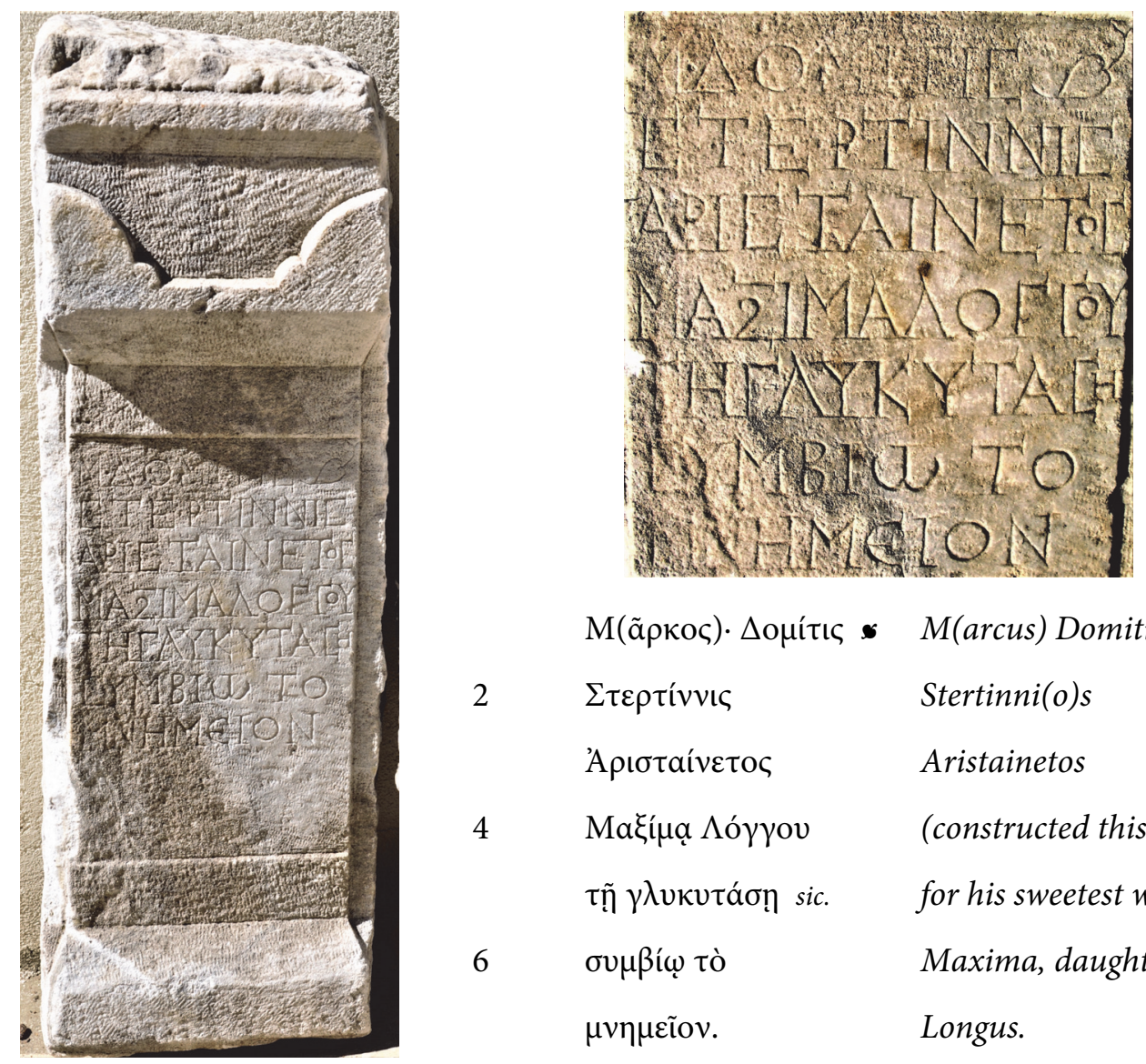

\begin{tabular}{|c|c|c|}
\hline & $\mathrm{M}(\tilde{\alpha} \rho \kappa о \varsigma) \cdot \Delta о \mu i ́ \tau ı \varsigma$ & $M(\operatorname{arcus})$ Domiti(o)s \\
\hline & $\Sigma \tau \varepsilon \rho \tau i ́ v v i \varsigma$ & Stertinni(o)s \\
\hline & 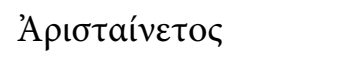 & Aristainetos \\
\hline & 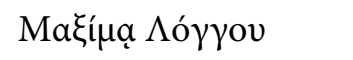 & (constructed this tomb) \\
\hline & 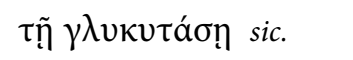 & for his sweetest wife \\
\hline & $\sigma v \mu \beta i ́ \omega$ тò & Maxima, daughter of \\
\hline & $\mu \nu \eta \mu \varepsilon \tilde{o}{ }$ & Longus. \\
\hline
\end{tabular}

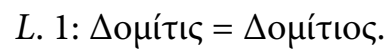

L. 2: $\Sigma \tau \varepsilon \rho \tau i ́ v v ı \varsigma=\Sigma \tau \varepsilon \rho \tau i ́ v v ı c$. For the -nn gemination in nomina gentilicia see Solin 2004, 176.

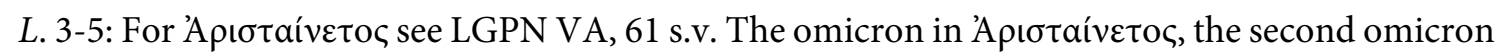

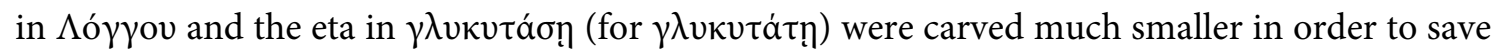
space and to avoid the spreading of names over two lines.

Date: Roman Imperial Period

\section{Funerary Inscription}

Marble stele; kept in the garden of the museum. Inv. no: 9642. Findspot unknown. Dimensions: H.: $71 \mathrm{~cm}$; W.: $50 \mathrm{~cm}$; D.: $17 \mathrm{~cm}$; Lh.: 1,5-2,5 cm.

Broken above. Pediment entirely missing. The monument appears to have had various panels on which miscellaneous sceneries were pictured. Amongst them, only the lowermost panel is fully preserved; only the lower section of the panel above is preserved. The forelegs of a horse are probably seen in this broken panel, but the depiction on the right is unclear. In the lower panel, a hunter fighting a bear that had stood up straight with his spear is depicted. 


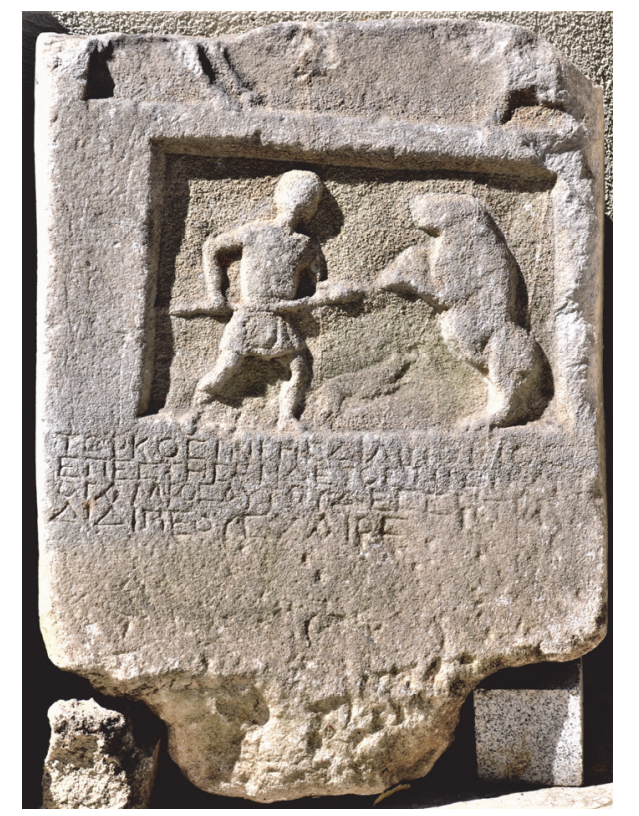

Below is seen a dog attacking the bear. Beneath the panel there is a carelessly carved inscription of four lines. The right portion of the inscribed area is weathered and the letters are barely legible. For bears in $\mathrm{Bi}$ thynia cf. Robert 1948, 90.
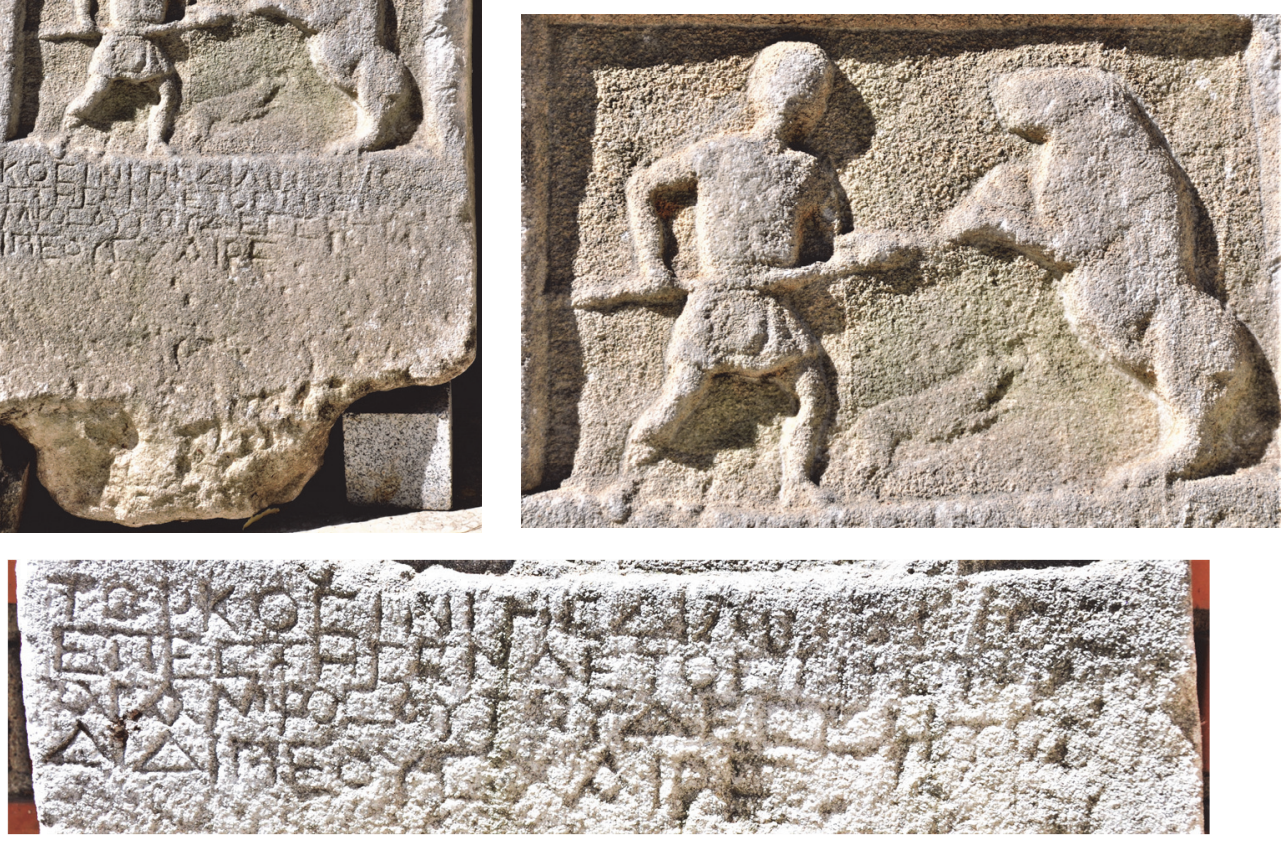

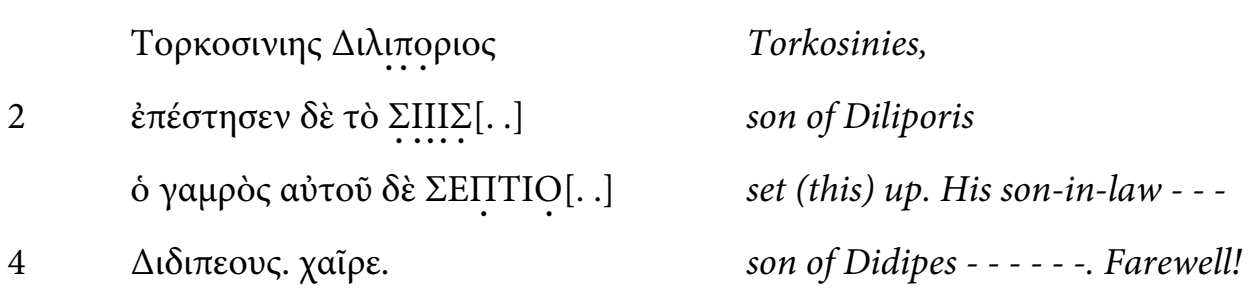

L. 1: Торкобıvın is hitherto unattested but there is no doubt that this is also a Thracian name as are the other names in the inscription. For the Thracian personal names beginning with Torc, see Dana 2014, 374-375. For the other Thracian name $\Delta$ i入ítopıৎ see Dana 2014, 131-132. Cf. also Mitchell 1978, 122.

L. 2: $\sum I I I \Sigma[$. . ]. unclear. Possibly a term relating to a grave should be expected in this line.

L. 3: इЕПТIO[. .]. Also not clear.

L. 4: $\Delta \mathrm{t} \delta \mathrm{\imath} \eta\rceil$ is most likely a Thracian personal name that is not documented to date. Some Thracian names beginning with Did- such as Didis, Didas, Didila etc. are recorded, see Dana 2014, 128-129. Detschew underscores that the names beginning with Did- are not confined to the Thracians, but also appear in Phyrgian onomastics. On Thracian names in Bithynia and the onomastics of the indigenous people of north-western Asia Minor in general see Özlem-Aytaçlar 2010, 506529 = Özlem-Aytaçlar 2012, 63-113 (in Turkish).

For a very similar relief attested in the north of Myra (Muskar/Belören) see Zahle 1979, 306-309. See also Özdilek 2008, 238 and 246 fig. 4; Özdilek - Çevik 2009, 286 and 289 fig. 5 and 13.

Date: Late Hellenistic, probably $1^{\text {st }}$ cent. B.C. 


\section{Funerary inscription of Ammia}

Marble stele, now in the garden of the museum. Inv. no: 9040. Findspot unknown. Dimensions: H.: $87 \mathrm{~cm}$; W.: 44-55 cm; D.: 21-23 cm; Lh.: 2-2,5 cm.

The pediment of the stele is broken and missing. A carved niche is on the front side of the stele, and the bust of a woman is depicted inside it. Her dress, hair and face are partly damaged. The folds of the woman's chiton are worked elaborately. Beneath the bust an inscription of two lines is carved.
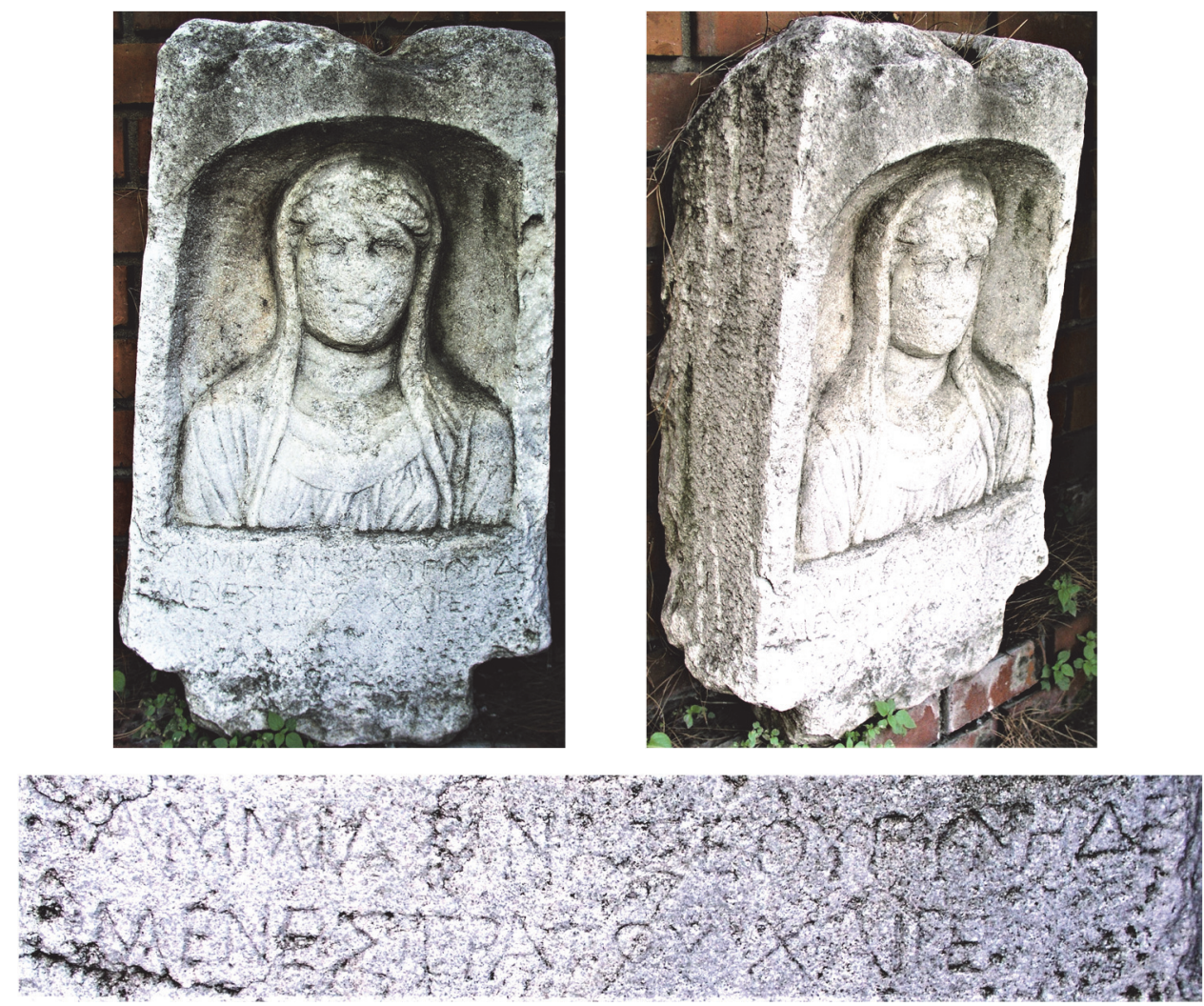

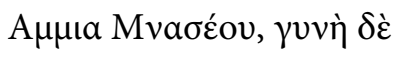

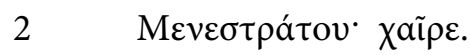

Ammia, daughter of Mnaseas, wife of Menestratos. Farewell!

L. 1: A $\mu$ нı is a Lallname, frequently attested in Phrygia, but also prevalent in the whole of Asia Minor, see Zgusta 1964, $\$ 57.16$. For the occurrences in Bithynia, see LGPN VA, 24 s.v. For

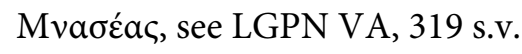

Date: Roman Imperial Period

\section{Funerary inscription of Alexandris}

Marble stele. Kept in the garden of the museum. No inventory number yet given. Findspot: İnegöl/Bursa; Dimensions: H.: $80 \mathrm{~cm}$; W.: 43,5 cm; D.: 7 cm; Lh.: 2,5-3 cm.

Broken above and below. Pediment and base missing. Otherwise complete. On the shaft two large wreaths are worked in low relief. The pair of wreaths were formed from bay leaves and were tied with ribbons. Beneath them is carved an inscription of five lines. 

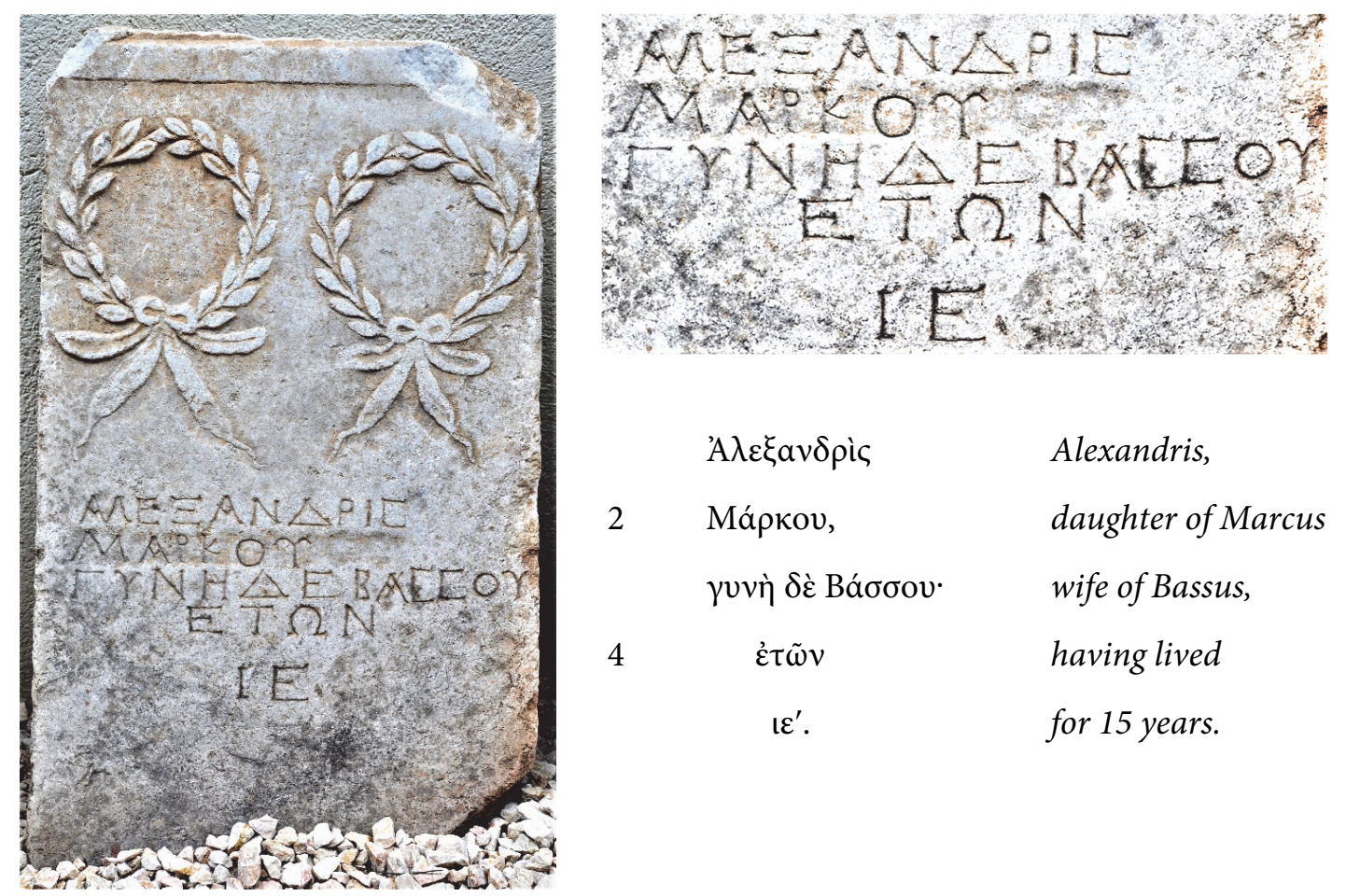

\begin{tabular}{|c|c|c|}
\hline & 'А $\lambda \varepsilon \xi \alpha v \delta \rho i \varsigma$ & Alexandris, \\
\hline \multirow[t]{2}{*}{2} & Ма́ркоv, & daughter of Marcus \\
\hline & 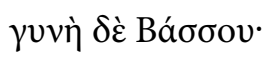 & wife of Bassus, \\
\hline & $\dot{\varepsilon} \tau \tilde{\omega} v$ & having lived \\
\hline & $\mathrm{t} \varepsilon^{\prime}$ & for 15 years. \\
\hline
\end{tabular}

L. 1: In Asia Minor, 'A $\lambda \varepsilon \xi \alpha v \delta \rho i ́ c$ is a poorly attested female name, see LGPN VB, 17 s.v.; LGPN VC, 14 s.v. Alexandris was apparently married when she was at the age of 15. Although it may seem that this is an early age for marriage, we have some other examples for so young brides from both Bithynia and its adjacent region Phrygia, see for example below no. 21: the funerary inscription of Fabia Rufa. Similarly in Prusa ad Olympum, the funerary inscription of a certain Soteris records that she had been married for 7 years when she passed away in the age of 20, which means that she was married at the age of 13, see IPrusa ad Olympum I, no. 165. In fact, in a funerary epigram from the territory of Amorion in Phrygia an even earlier marriage age is recorded. According to this text, the deceased woman was married at the age of 11 to her husband, see MAMA VII, $258=$ SGO III, no. 16/43/04. Thonemann $(2013,134-135)$ asserts that the average marriage age in Phrygia was around 16. For the age at first marriage, see also Saller 1994, 25-41; Scheidel 2007, 389-402.

L. 2: There are the traces of erasure under the name of Marcus, indicating that something else was carved here erroneously and then replaced with the correct one. On the erased spot the last two letters, possibly an omicron and upsilon are still visible.

Date: Roman Imperial Period

\section{Funerary inscription of Tiberius Claudius Phillys}

Marble stele placed in the garden of the museum. No inventory number yet given. Findspot unknown. Dimensions: H.: 67 cm; W.: 36 cm; D.: 6,5 cm; Lh.: 1; 4; $6 \mathrm{~cm}$.

Broken above, and pediment missing. At the top the lower part of a wreath is visible. Two fourleaf rosettes on each side are carved below the wreath, and two ribbons of the wreath are placed between the rosettes. Below them an inscription of six lines inside a tabula ansata is carved. 


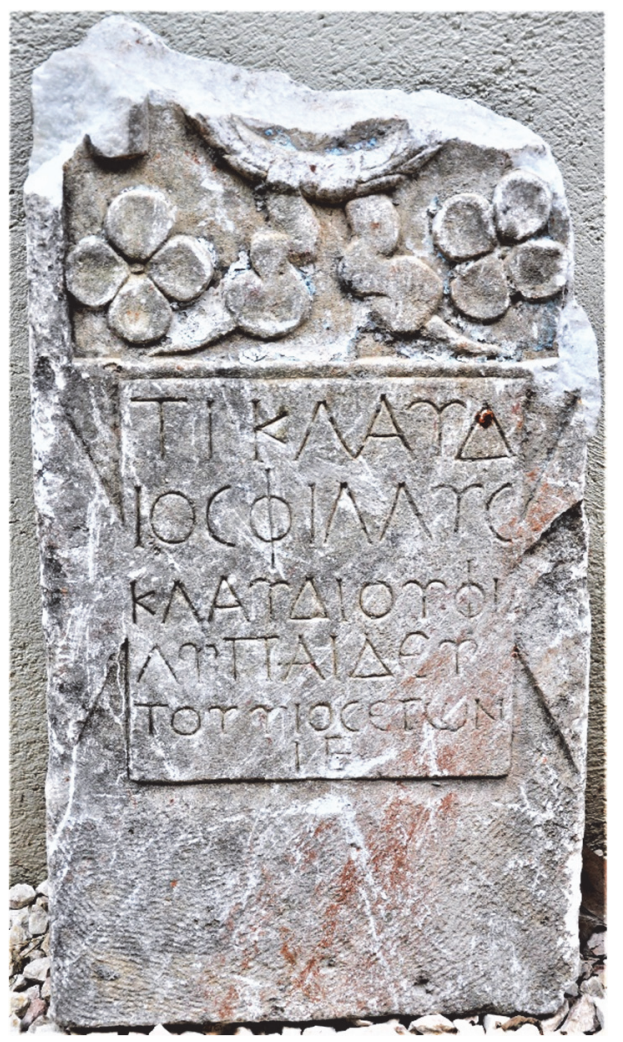

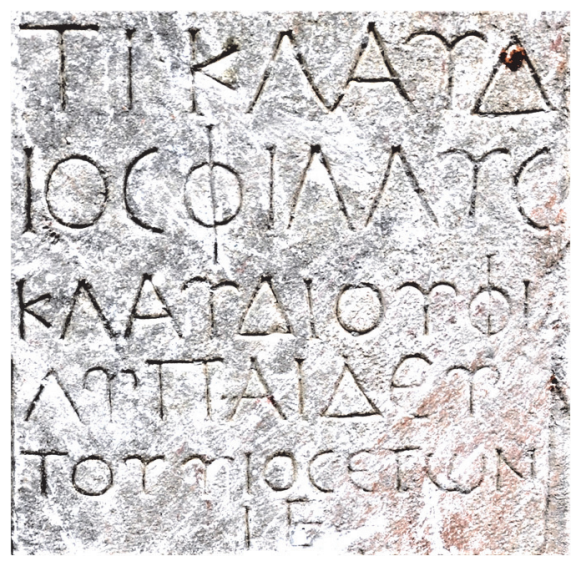

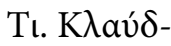

2

เoৎ $\Phi \dot{\lambda} \lambda \lambda v \varsigma$

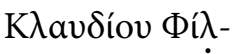

$4 \lambda \lambda^{2} \pi \alpha \mathrm{\delta} \delta v-$

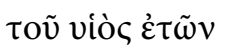

6

$\left\llcorner\varepsilon^{\prime}\right.$.

Ti(berius) Claudius Phillys, son of the teacher Claudius Phillys, having lived for 15 years.

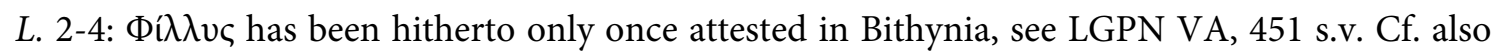
Robert, OMS VI, 57-69 who provides an extensive survey of the names terminating in -vc. (for

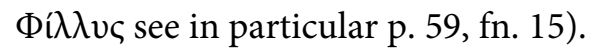

L. 4-5: $\pi \alpha ı \delta \varepsilon v \tau o \tilde{v}$. The father of the deceased boy was a teacher. From one posthumous honorary inscription in the Bursa Museum we know of another teacher, see IPrusa ad Olympum I, no. 1009. Even though Th. Corsten, referring to Robert - Robert 1948, 89-91, states that paideutes is rarely attested in the epigraphic record, plenty of paideutai are known from both Asia Minor and the ancient world in general. The evidence even suggests that they formed associations, see Paz de Hoz 2015. For paideutes, see also Paz de Hoz 2007, 309-310. Cf. also Del Corso 2007, 141-190.

Date: Roman Imperial Period

\section{Funerary Inscription of Tatia}

Marble stele, now in the garden of the museum. Inv. no: 2016/26. Findspot: Kestel/Bursa. Dimensions: $\mathrm{H} .: 86 \mathrm{~cm}$; W.: $50 \mathrm{~cm}$; D.: $7 \mathrm{~cm}$; Lh.: $3-4 \mathrm{~cm}$.

The surface of the stele with its triangular pediment is strongly weathered. The monument possibly stayed in the water for a long time so that the marble has totally lost its smoothness. The top of its middle acroterium is broken off. The middle part of the base is also lost. A star-like rosette of six leaves is placed in the pediment. On the shaft a panel in which a wreath, two star-like rosettes and some objects symbolising female activities such as a mirror with handle, a comb, a wool basket, a spindle and a distaff are depicted. An inscription of four lines is carved beneath the relieffield. Due to the outbreak the last line is hardly legible. 

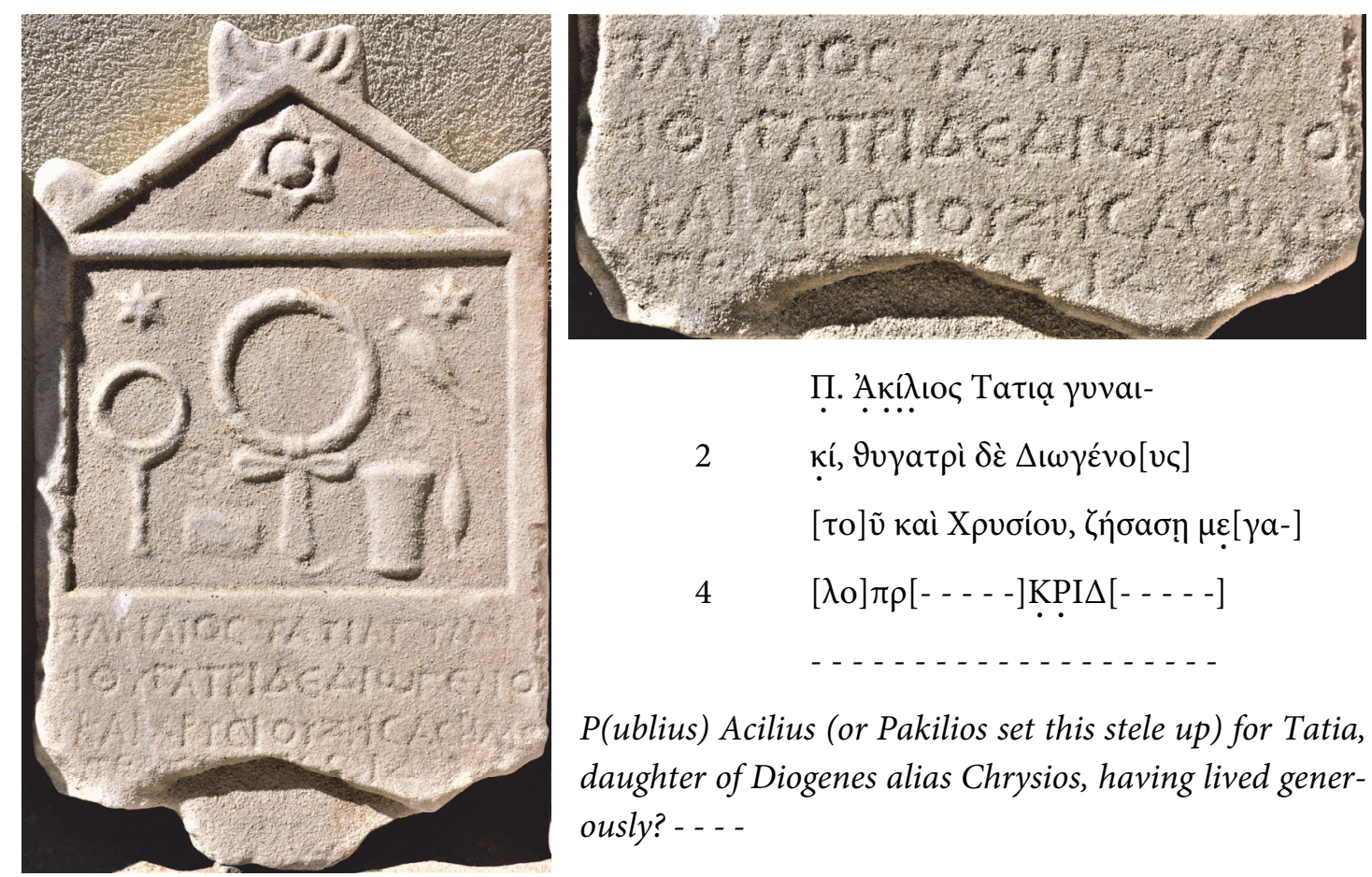

П. ’.ํ..ı..

2

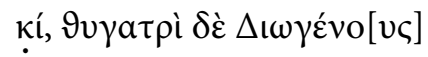

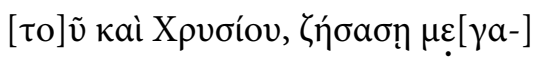

4

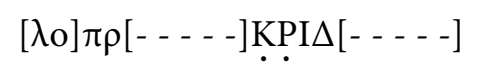

P(ublius) Acilius (or Pakilios set this stele up) for Tatia, daughter of Diogenes alias Chrysios, having lived generously? - - - -

L. 1: The name of the person who constructed the funerary stone is not very clear on the stone. It is either Pakilios (for this name see LGPN I, 357 s.v.) or much more likely P(ublius) Acilius. The nomen gentilicium Acilius is once attested in Mysia, see LGPN VA, 14 s.v.

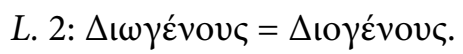

L. 3: The name X

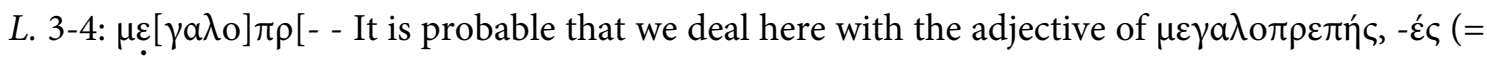
generous, benevolent), which may indicate that the deceased Tatia was a munificent person when she was alive.

Date: Roman Imperial Period

\section{Funerary Inscription of Paideros}

Whitish marble stele, now in the garden of the museum. Inv. no: 2009/69. Findspot: Kestel/Bursa. Dimensions: H.: 117 cm; W.: 42-51 cm; D.: 15-16 cm; Lh.: $2 \mathrm{~cm}$.

Slightly broken at the top left corner. Its surface is weathered and has plenty of small damages and scratches. Triangular pediment decorated with acroteria and a central rosette. In the panel beneath the pediment a large wreath is flanked at either side by a rosette. In the second panel three standing figures are depicted. It is clear from their garments that the figure on the right is a woman and the one on the left a man. A male child is standing between them. A barely legible inscription of six lines is carved beneath this panel. 


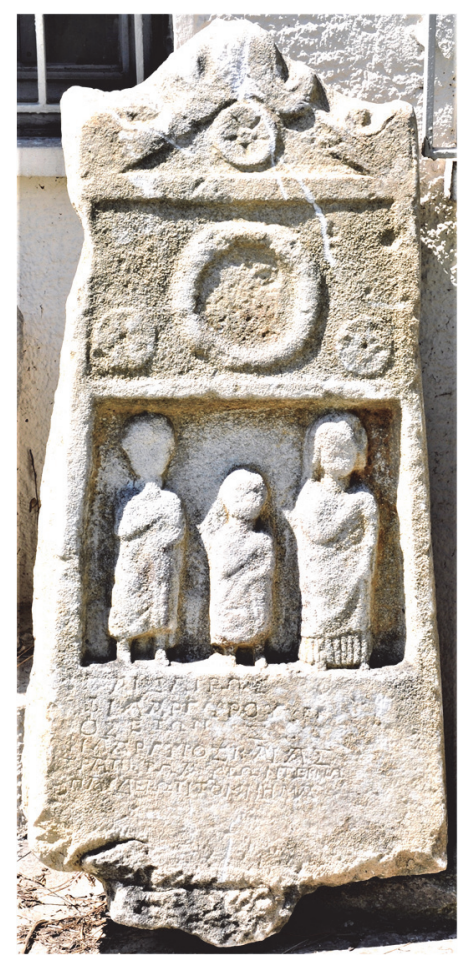

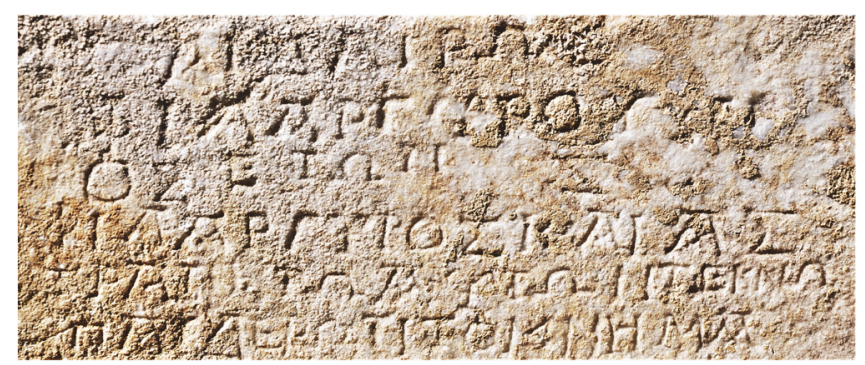

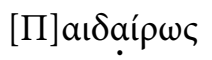

2

Фı\арүúpov vióc $\cdot \dot{\varepsilon} \tau \tilde{\omega} \nu \varsigma^{\prime}$ or $\zeta^{\prime}$.

4

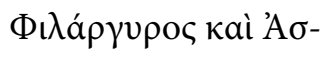

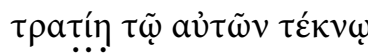

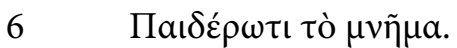

Paideros, son of Philargyros, having lived for 6 (or 7 years). Philargyros and Astratie? (constructed) this memorial for their child Paideros.

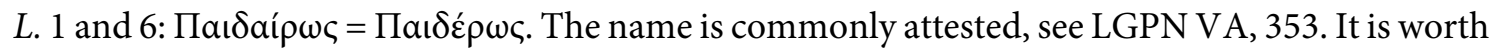
mentioning that the name is written differently in the beginning and at the end.

L. 2: Фıגá $\rho \gamma v \rho o \varsigma$ is poorly attested in Mysia, see LGPN VA, 446 s.v.

L. 3: غ่ $\tau \tilde{\omega} \nu \varsigma^{\prime}$ or $\zeta^{\prime}$.

L. 4-5: The reading of the letters after Astra- is dubious. For Astrateia, see Pape - Benseler 1884, 164. It is possible that the woman originally comes from an area where still some Ionic pronounciation had survived.

Date: Roman Imperial Period

\section{Funerary inscription of Demetrios and Mainia?}

Fragment of a marble stele, placed in the garden of the museum. Till now no inventory number was given. Findspot unknown. Dimensions: H.: 43 cm; W.: $51 \mathrm{~cm}$; D.: $13 \mathrm{~cm}$; Lh.: $1,5 \mathrm{~cm}$.

Broken above and below. Base and pediment missing. The stele is seemingly decorated with panels, yet only the middle one is preserved. Inside the remaining panel an elaborately worked banquet scene is depicted. The deceased reclines on a couch and holds a wreath in his hand. His wife in the pudicitia pose is sitting in front of him. Behind the woman there is a servant girl, depicted in a smaller scale. Another servant is dealing with some objects (oinochoe?) on a table visible behind the man. A partly damaged inscription of two lines is written beneath this secenery. Only paws belonging possibly to an eagle have remained from the upper panel. Having at least 3 panels, this stele might belong to the group of "Stockwerkstelen" (Cremer 1991, 27-31). 

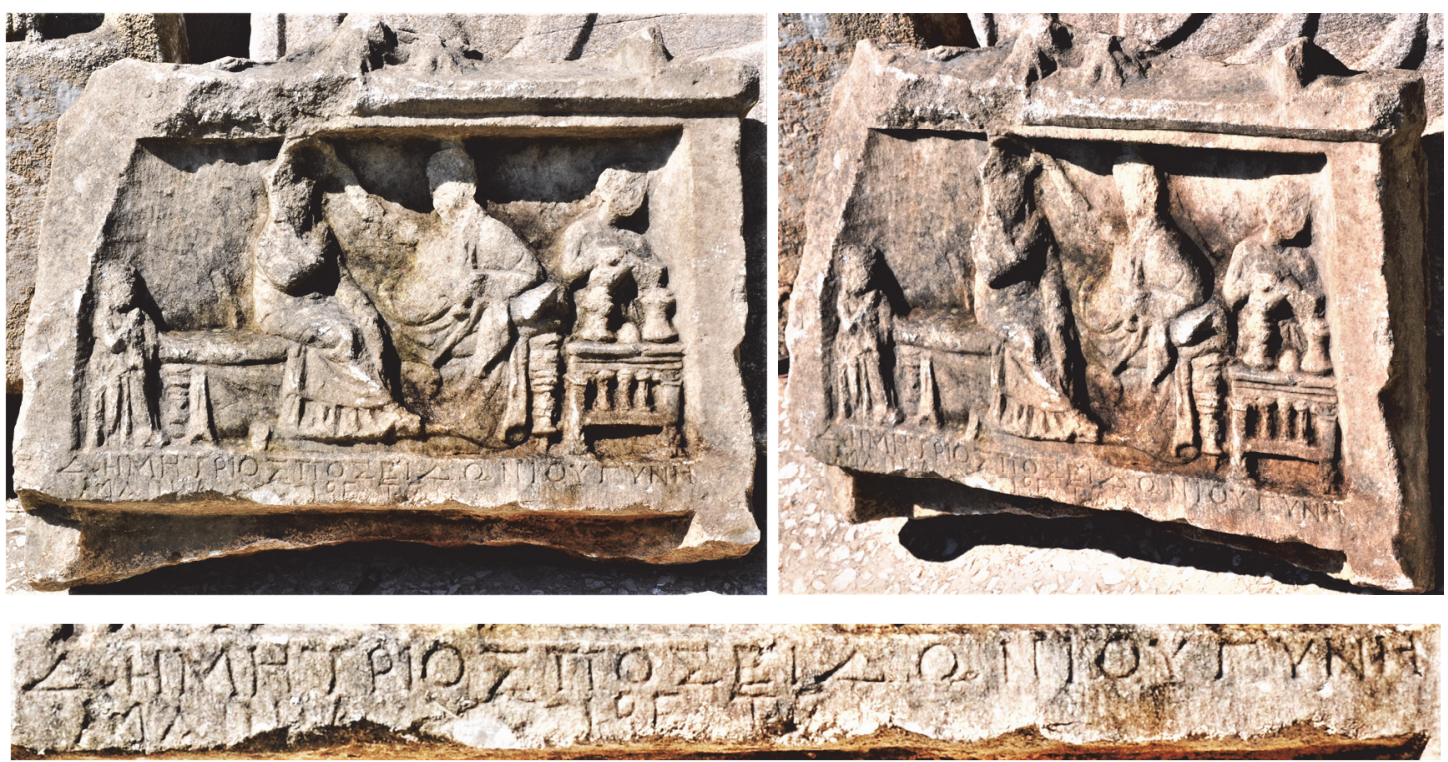

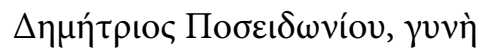 \\ 2

$$
\text { Maıvía, } x[\alpha] i ́ \rho \varepsilon^{v} \tau \varepsilon .
$$

Demetrios, son of Poseidonios,

(and his) wife Mainia, farewell!

L. 2: Maivia is not listed in any volume of LGPN, but there are at least two occurrences of this name, both in Argeia, IG IV, 620 and 647. It is not to be ruled out that the first iota is simply a scratch and the name is far more attested Mavia.

Date: Due to the relatively small letters as well as because of its belonging to the group of stelai with storeys (Stockwerkstele), that were prevalent in the Late Hellenistic Period, this monument should presumably be dated into the Late Hellenistic or Early Imperial Period.

\section{Funerary Inscription}

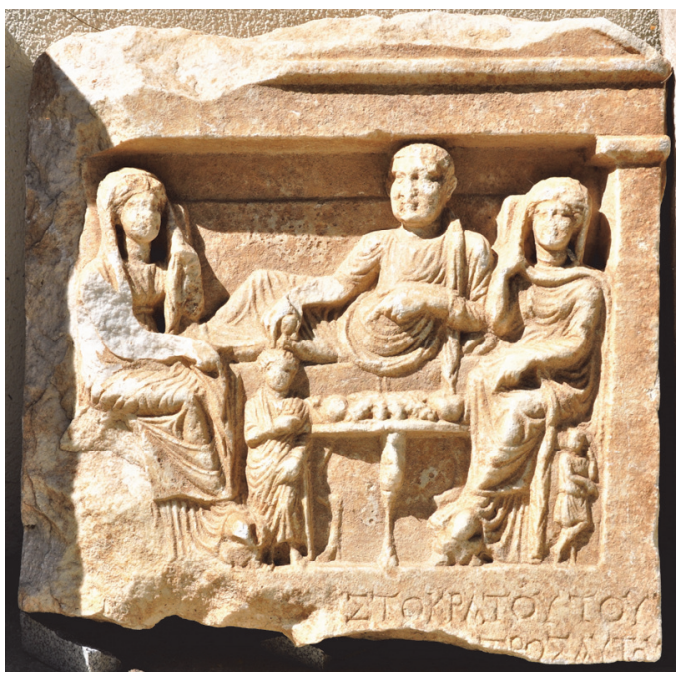

Fragment of a marble stele; kept in the garden of the museum. No inventory number is yet given.

Findspot: Doğla village/Karacabey/Bursa. Dimensions: H.: $59 \mathrm{~cm}$; W.: $61 \mathrm{~cm}$; D.: $12 \mathrm{~cm}$; Lh.: $2,5-3 \mathrm{~cm}$.

Broken above and below. Pediment almost entirely lost. A banquet scene is depicted. The man reclines on a couch; on either side he is accompanied by a female figure. Probably the woman on the right of the man is his wife, while the one on the left could be his daughter. The small boy in front of the man may be his son. Beside him a tripod table with fruits is placed. Below the woman on the right a servant is visible. Beneath the scene a fragmentary inscription of two lines is preserved.

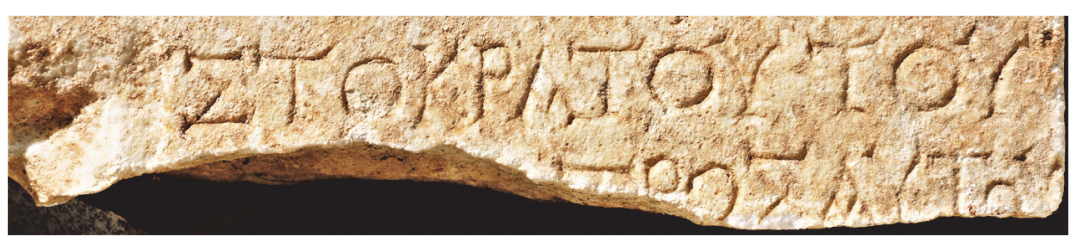




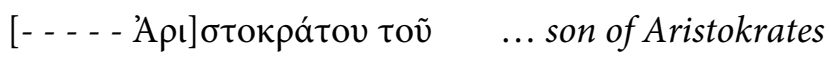

$$
\begin{aligned}
& 2 \text { [- - . - - - ] }
\end{aligned}
$$

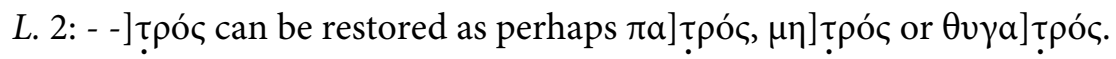

Date: Roman Imperial Period

\section{Funerary Inscription of Diogenes and Fabia Rufa}

Marble stele, now in in the garden of the museum. Inv. no: 2016/23. Findspot: Çitli village/İnegöl/ Bursa. Dimensions: H.: $181 \mathrm{~cm}$; W.: $72 \mathrm{~cm}$ (top); $77 \mathrm{~cm}$ (below); D.: $13 \mathrm{~cm}$ (top); $20 \mathrm{~cm}$ (below); Lh.: 1; 3; 4,5 cm. Dim. of the block on which the stele stands: H.: $32 \mathrm{~cm}$; W.: $94 \mathrm{~cm}$; D: $22 \mathrm{~cm}$.

Ed.: Lafl1 - Bru 2016, 110-111 no. 9. Cf. Taeuber 2016, 288-290.

The big stele was found together with the large and heavy block which served as its base. Today, it is not placed on this block, but on the floor. It is broken above, and there are many small breaks and scratches on it. It is decorated with a triangular pediment, in which a wool basket, a box-like object and two small figures being probably scent bottles are sculptured. The right corner acroterion is broken. Beneath the pediment two laurel wreaths are depicted. In the bottom section of the stele a large, now empty niche is cut out. Above the niche two small rosettes are carved as a kind of decoration. Between the niche and the laurel wreaths an inscription of 6 lines is written on a large tabula ansata, however, further 5 lines, the beginning of the epitaph, are not very elegantly placed above the tabula, and finally the last line of this epitaph is carved below the tabula. It is very likely that the first 5 rows were added when the tabula was already described.
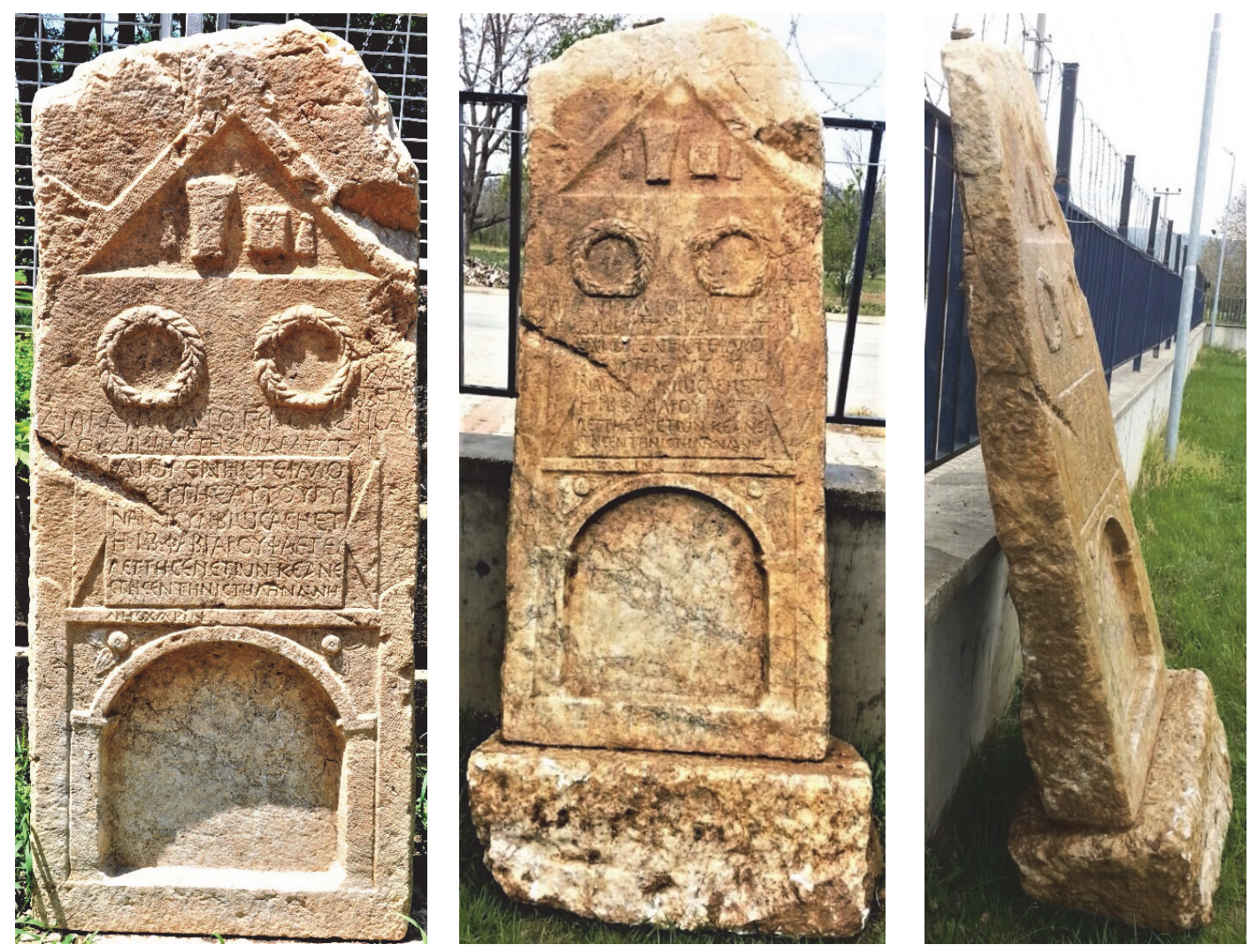

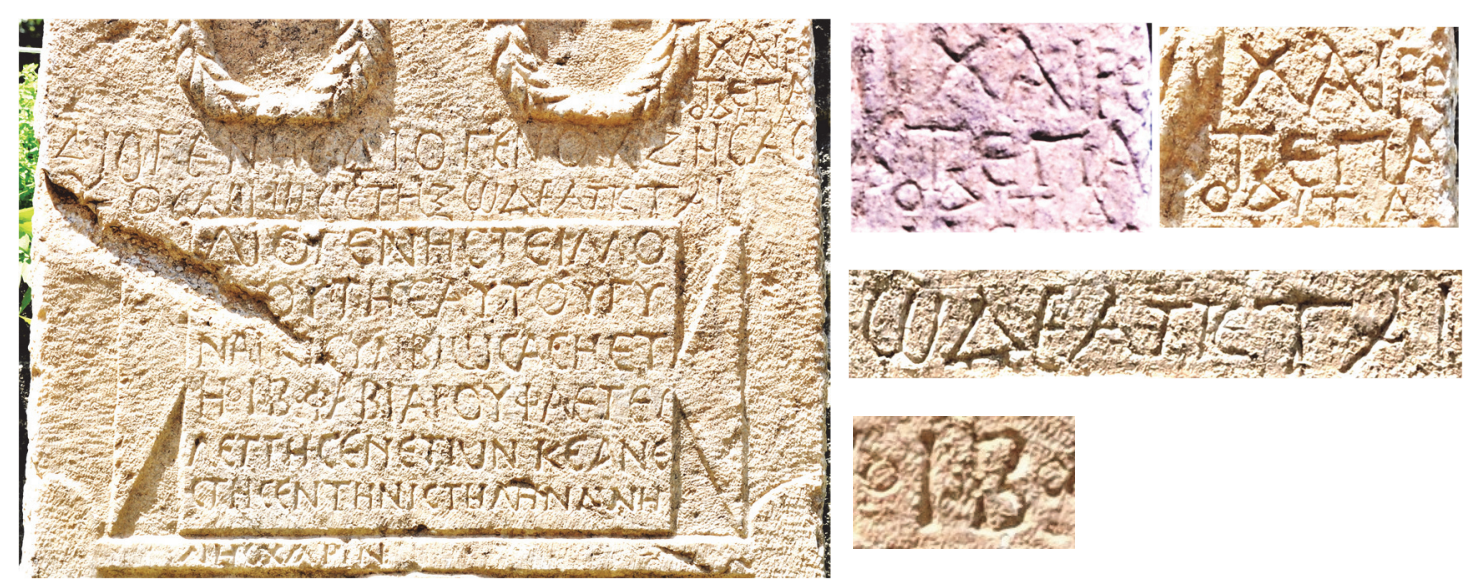

xaípe-

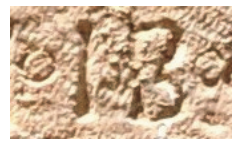

$\tau \varepsilon \pi \alpha-$

Greetings wayfarers!

$\rho \delta \delta \tilde{\tau} \tau[\mathrm{l}]$.

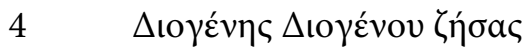

Diogenes, son of Diogenes, having lived

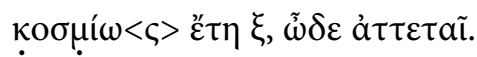

for 60 years decently. Alas!

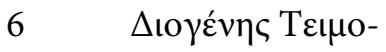

Diogenes, son of

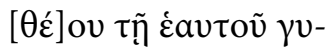

Teimotheos, set up this stele

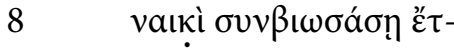

in memory for his wife Fabia Rufa

$\eta^{\circ}{ }^{\circ} \beta^{\circ o} \Phi \alpha \beta i a ̣{ }^{\circ} P o u ́ \varphi \underline{~ \varepsilon ̇ \tau \varepsilon !-~}$

that lived together with him

$10 \lambda \varepsilon_{\varepsilon} \tau \tau \eta \sigma \varepsilon v \varepsilon \dot{\varepsilon} \tau \tilde{\omega} v \kappa \varepsilon^{\prime} \alpha \dot{\alpha} v \varepsilon \varepsilon^{-}$

for 12 years and

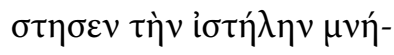

died at the age of 25 .

$12 \mu \eta \varsigma \chi \alpha \dot{\alpha} \rho เ v$.

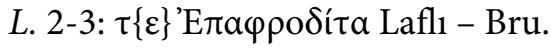

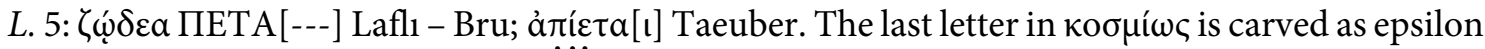
on the stone. Before kappa is seen another letter or a leaf motif but cannot be understood because

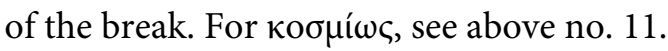

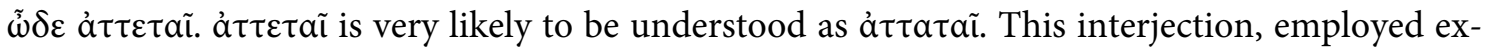
clusively in the poetic texts expressing pain and vexation has never been epigraphically attested. According to Nordgren $(2015,108-110)$, it has been recorded 11 times in total, 9 occurences in

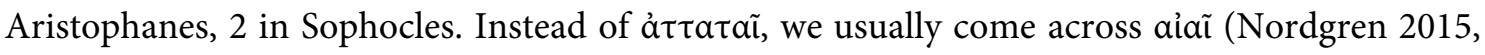
130-133; Y1ld1z 2019, p. 588) or $\varphi \varepsilon \tilde{v}$ in the funerary epigrams.

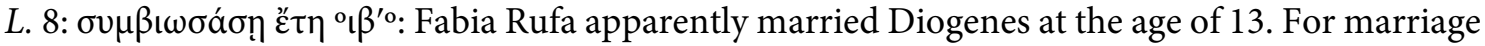
at an early age cf. above no. 15 .

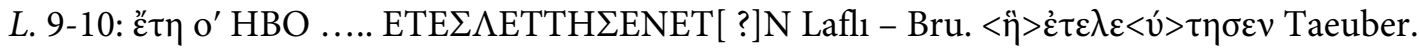

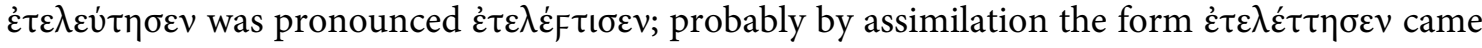
into being. At the end of line 9 a letter (either iota or sigma) may be read, but in reality it was a breakage in the stone. $\dot{\varepsilon} \tau \tilde{\omega} v$ is carved as being ETIUN on the stone. 


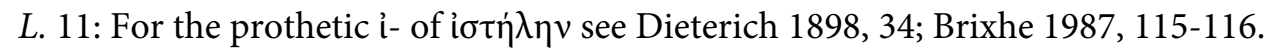

Date: Roman Imperial Period

\section{Funerary Inscription of Gaius Murius Valens, Muria Prima and their son Rufus}

Marble stele, now in the garden of the museum; till now without inventory number given. Findspot: Karadere Mevkii/İnegöl/Bursa. Dimensions: H.: 122 cm; W.: 69 cm; D.: 15 cm; Lh.: 3,5-4 $\mathrm{cm}$.

Ed. Laflı - Bru 2016, 111-112 no. 10.

The upper part above the pediment is broken off. The niche below is also largely broken, and the base is not preserved. The lower portions of two wreaths are seen on either side of the pediment. A Gorgo head whose face is damaged, is placed in the pediment. In the panel beneath the pediment there are three standing figures, which are presumably to identify with mother, father and son mentioned in the inscription. Beneath the panel an inscription with six lines is carved. Inside the niche area a falx arboraria (pruning hook), a comb and a spindle? are depicted.
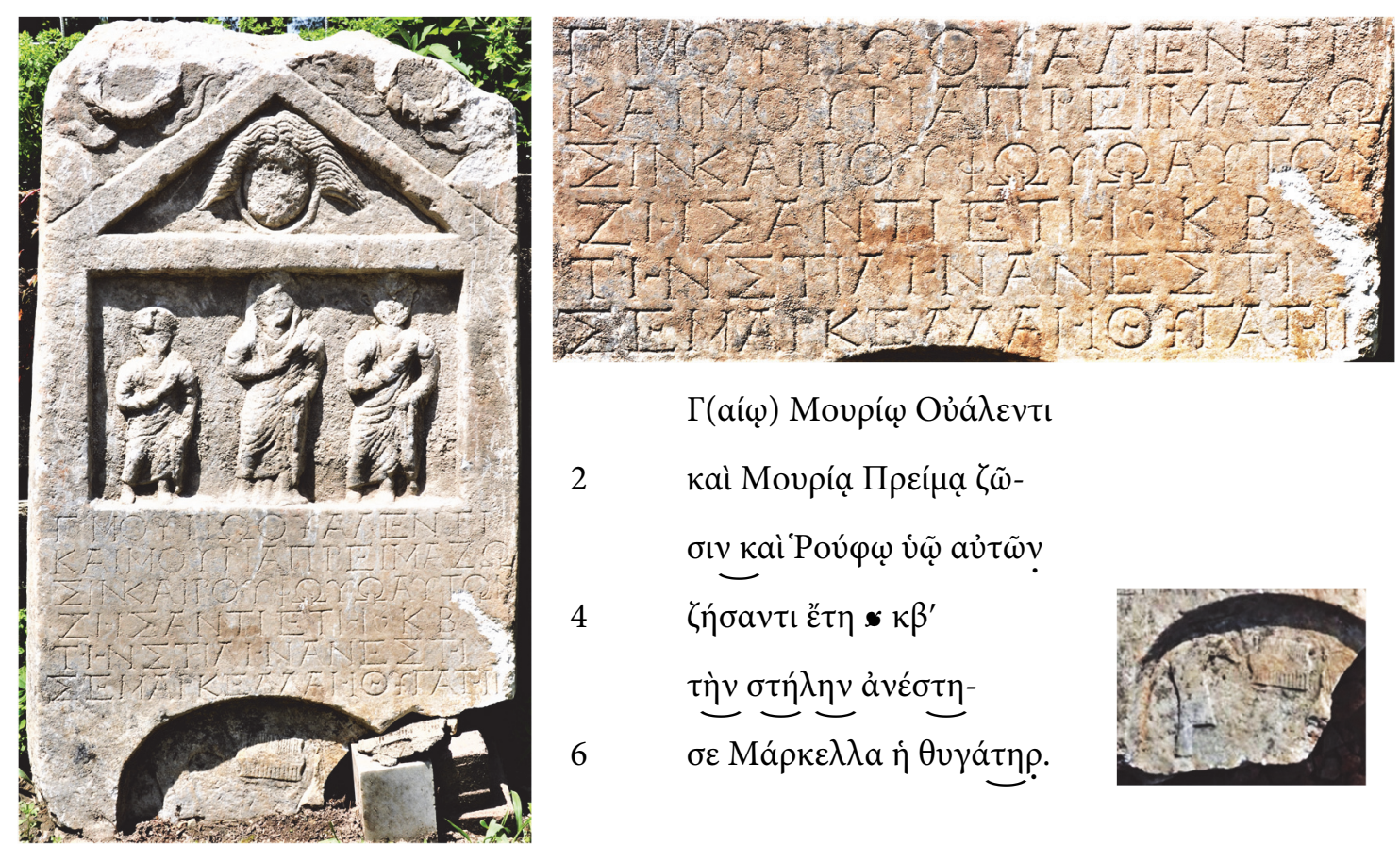

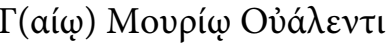

2

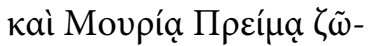

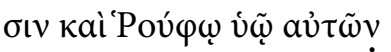

4

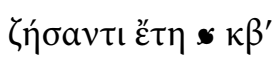

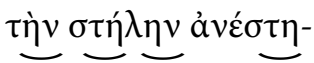

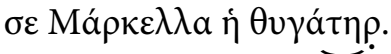

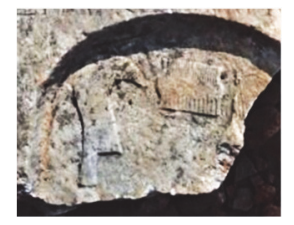

The daughter Marcella set this stele up for G(aius) Murius Valens and Muria Prima while still living and for their son, having lived 25 years.

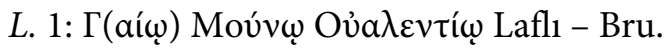

L. 1-2: In Latin inscriptions both Murius and Murrius are well attested, cf. CIL V, 2245; CIL VIII, 27512; Schulze 1991, 196 and 424.

L. 2: Mouvạ Lafl1 - Bru.

L. 3: vị̣̂ Laflı - Bru.

Date: Roman Imperial Period 


\section{Funerary Inscription of Rhadamanthys}

Marble stele, now housed in the Bursa Museum. Inv. No: 2014-65. Found during the excavation of a football field by the Directorate of Technical Works of İnegöl Municipality at İnegöl/Bursa. Dimensions: H.: 124 cm; W.: 67-70 cm; D.: 14-17 cm; Lh.: 2-2,5 cm.

Ed. Lafl1 - Bru 2016, 112-113 no. 11.

The central acroterion, a big part from the right corner with half the acroterion, and the lower right corner of the stele are broken off. A triangular pediment is sculpted in flat relief on the stone surface. Inside this pediment a large wreath is placed, and outside of the gable two small rosettes are depicted on both sides. An inscription of one line is written on the pediment's bottom profile. On the shaft of the stele there is a large niche, in which an papyrus scroll, a kalamotheke, and a diptychon are depicted. $\chi \propto$ ĩ $\rho \varepsilon$ is inscribed on the scroll. The bowllike cavity on the niche's bottom may have been used for libations.
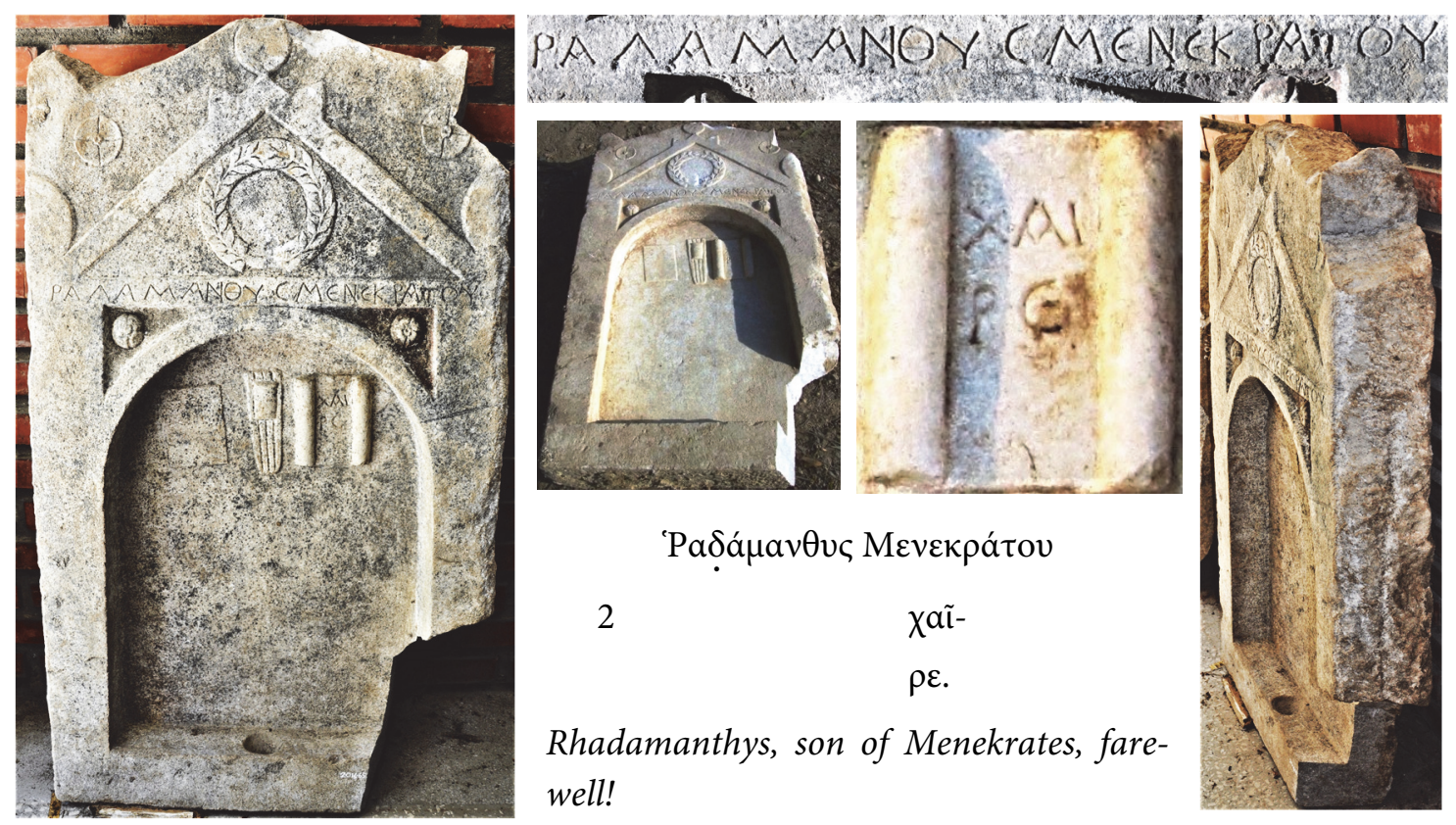

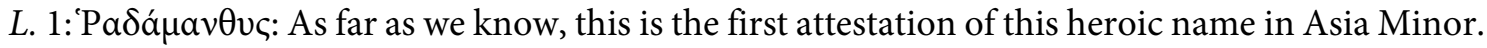
For the name, see LGPN II, 390 s.v.; LGPN IIIA, 384 s.v. Cf. the phyle Rhadamanthis in Kaunos, which is named after the hero, Marek 2006, no. 64.

Date: Roman Imperial Period

\section{Funerary Inscription of Hipparchos}

Marble stele. Kept in the garden of the museum. No inventory number given yet. Findspot: Kurtul village/Gemlik/Bursa. Dimensions: H.: 89 cm; W.: 29 cm; D.: 8,5 cm; Lh.: 2 cm.

Ed: Lafl1 - Bru 2016, 113 no. 12.

Slim and tall stele; segment pediment in which a facing eagle with spread wings sets about devouring a serpent whose tail the bird retains with his right claw. The upper margin of the stele is now damaged, but we provide a photo which was taken when the monument was still intact. The stele consists of two panels. The first one shows a banquet scene: The man reclines on a couch and holds a wreath in his right hand, attended by his seated wife in front of him and by a servant girl 
who is standing behind the woman and is carrying a basket. Behind the man a male servant dealing with the objects on the table is depicted. It is interesting to see that in this composition the table is not a tripod but rather has four legs; it is placed not in the centre but on the edge. In the other panel a man seated on a stool is sculpted. Opposite to him a second man standing and putting his left foot on a footrest is shown. Beneath this panel an inscription of two lines is carved.
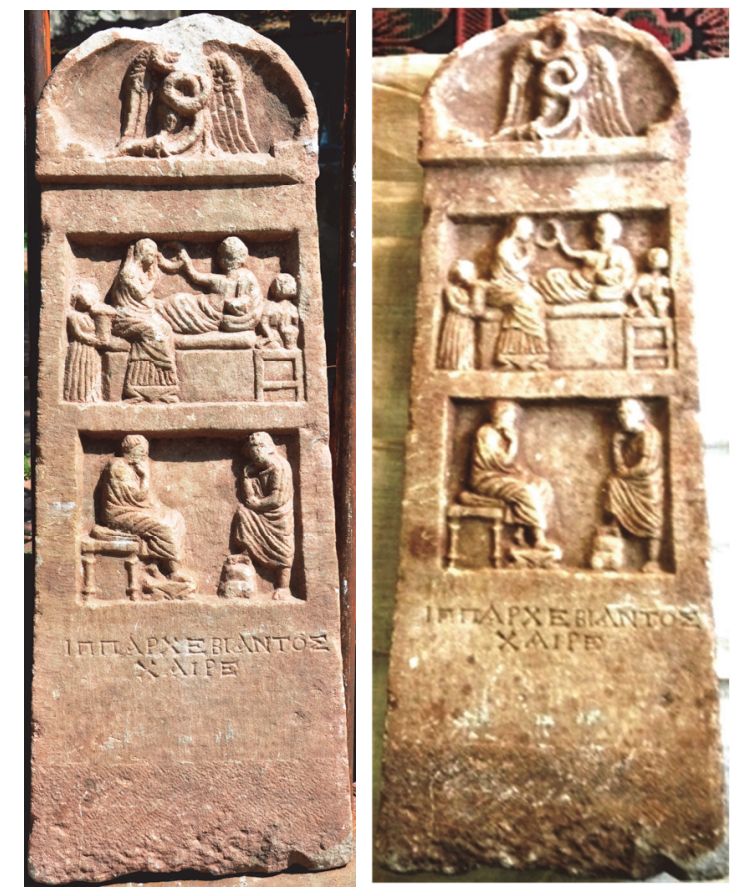

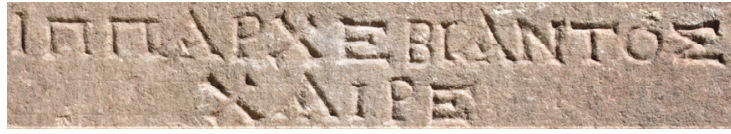

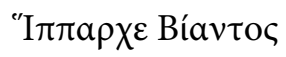

2

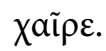

Hipparkhos, son of Bias, farewell!

L. 1:"I $\pi \pi \alpha \rho \chi$. Cf. above no. 5 which also records the name of the deceased in the vocative case. For Bíac, see LGPN VA, 101 s.v.

Date: Late Hellenistic.

In Bursa Museum, there is yet another stele in whose pediment is similarly filled with an eagle fighting against a snake (Inv. no. 9049). For the same motif, cf. also IPrusa ad Olympum, no. 80 (found at Hamzabey village near İnegöl). See also Rodríguez Pérez 2010, 1-18.

\section{Funerary inscription of Charmides}

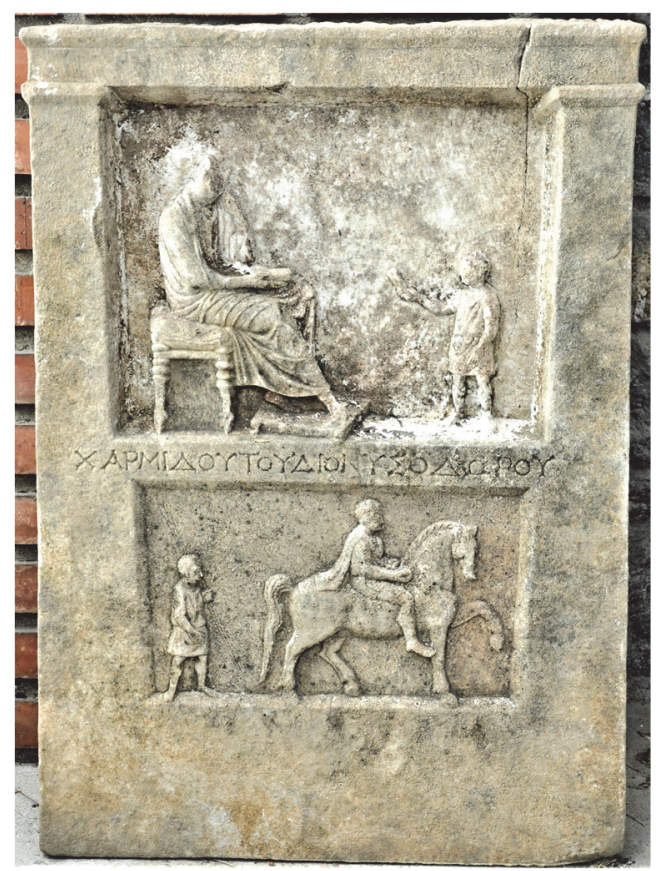

Marble stele, placed in the garden of the museum. Inv. no: 3193. Findspot: Dağkadı village/Karacabey /Bursa. Dimensions: H.: 87 cm; W.: 61 cm; D.: 21 $\mathrm{cm}$; Lh.: 1,5-2 cm.

Ed: Lafl1 - Bru 2016, 114-115 no. 14.

Base and pediment of this rectangular stele are not preserved. Upper part moulded; on the shaft there are two panels. The upper panel contains a scene in which a man seated on a stool holds a roll. His feet are rested on a low footstool. His garment is richly folded. In front of the man a male child holding a roll is standing. This composition presumably depicts a teacher and his pupil or student. Inside the panel traces of the original colours are preserved. Beneath the first panel an inscription of one line is inscribed. The second panel shows a man riding his horse; behind him a servant holding a thin rod. 

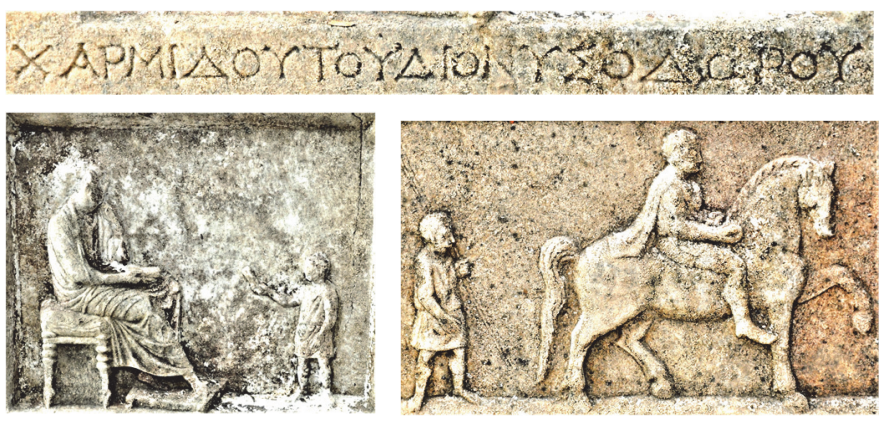

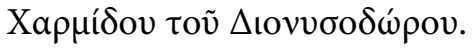

(The stele of) Charmides, son of Dionysodoros.

Date: Late Hellenistic

\section{Uninscribed Stelai}

\section{Funerary stone}

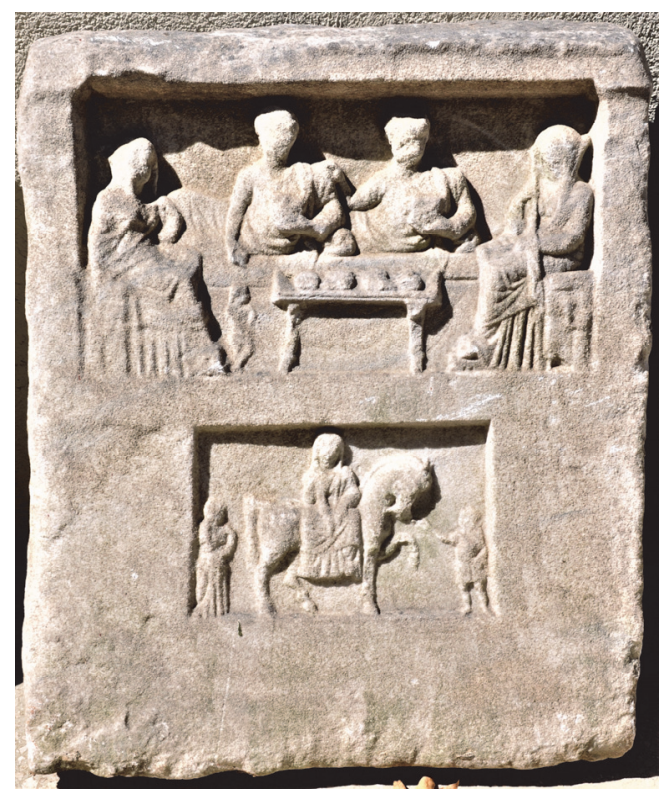

Marble stele; kept in the garden of the museum. Inv. no: 3186. Findspot: Gönen/Balıkesir. Dimension not recorded.

Neither pediment nor base of this rectangular stele are preserved. It contains two panels. All the figures are heavily abraded so that many details are lost. The upper panel shows a banquet scene in which two men reclining on a couch are accompanied by two women on either side. The women depicted in the pudicitia pose are sitting on stools. On the central table fruits are depicted. The panel below is smaller and centered. Inside the panel a woman riding a horse is sculpted, a stableboy who is leading the horse and a female figure behind the horse are represented.

Date: 2.-3. cent. A.D.

\section{Funerary stone}

Marble stele; kept in the garden of the museum. Till now no inventory number is given. Findspot: Turşucu village (Gedelek Mahallesi)/Orhangazi/Bursa. Dimensions: H.: 77 cm; W.: 103-113 cm; D.: $12-45 \mathrm{~cm}$.
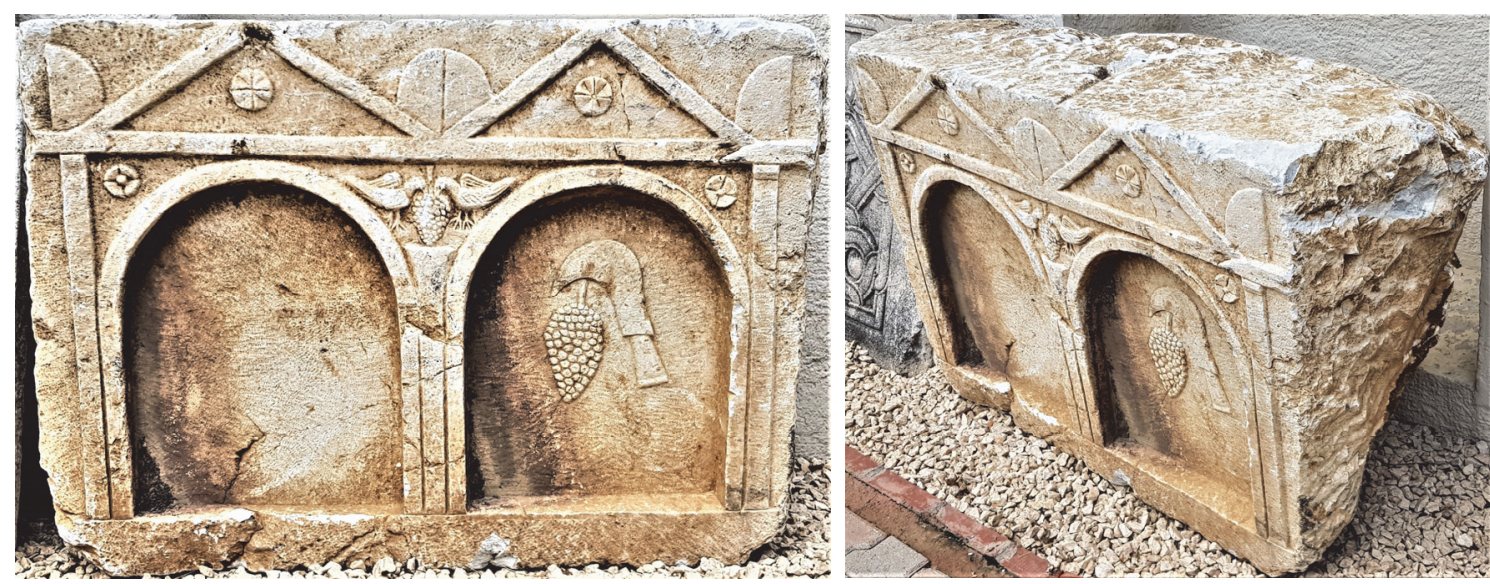

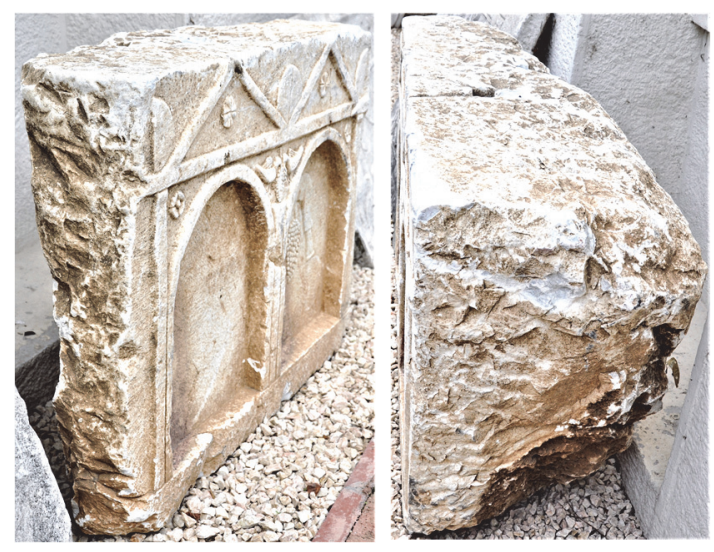

Only the frontside of this somewhat rough stone block is hewn. The top of the stele is roughly smoothed and there are 3 dowel holes, indicating that the stele was placed in an architectural construction. The front face is worked in the form of two adjacent stelai with acroteria and triangular pediments. Inside both pediments rosettes are depicted. The niche on the right was left blank, in the left niche a falx arboraria and a bunch of grapes are carved in relief.

A single rosette is above each niche on the outer side. On the inner side between both niches a bunch of grapes with a pigeon on either side is carved.

Date: Roman Imperial Period

\section{Funerary stone}

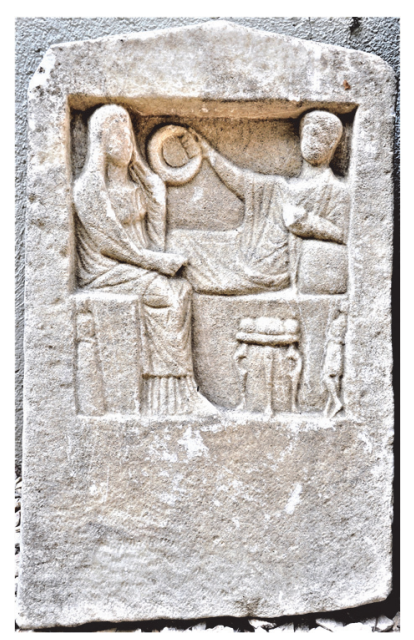

Marble stele; now in the garden of the museum. Inv. no: 2018/13. Findspot unknown. Dimensions: H.: $53 \mathrm{~cm}$; W.: $33 \mathrm{~cm}$; D.: $7 \mathrm{~cm}$.

This small rectangular stele has a low triangular pediment and no base. On the shaft a typical banquet scene is pictured. The man reclining on a couch holds a wreath in his right hand. In front of him a woman in the pudicitia pose is sitting. In front of the kline a tripod table with fruits is placed. To the right of the tripod, in the right corner a tiny male servant and opposite in the left corner a tiny female servant are ready for serving their masters.

Date: Roman Imperial Period

\section{Funerary stone}

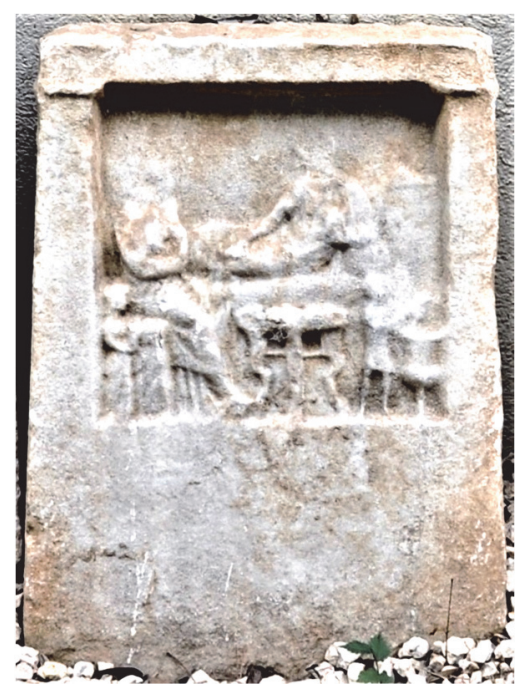

Marble stele, now in the garden of the museum. Till now no inventory number was distributed to it. Findspot: Karacabey/Bursa. Dimensions: H.: $61 \mathrm{~cm}$; W.: $40 \mathrm{~cm}$; D.: $16 \mathrm{~cm}$.

The rectangular stele has no pediment and base. A banquet scene is depicted on the stele. A man is reclining on a couch, whereas in front of him a woman in the pudicitia pose is seated. In front of the kline a tripod table with fruits is placed. To the right of the tripod a small male servant preparing wine for drinking is standing besides a krater. In the opposite corner, next to the lady of the house, a small female servant is waiting for her commands.

Date: Roman Imperial Period 


\section{Funerary stone}

Marble stele; kept in the garden of the museum; without inventory number. Findspot: Tirilye/ Mudanya/Bursa. Dimensions: H.: $87 \mathrm{~cm}$; W.: $50 \mathrm{~cm}$; D.: $10 \mathrm{~cm}$.

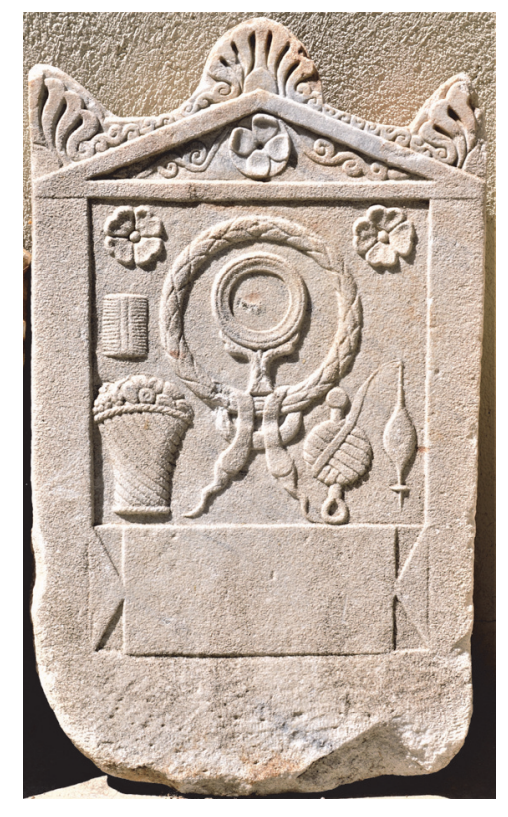

The stele is complete and has a triangular pediment elaborately decorated with corner and top acroteria and a base having small breaks. Inside the pediment is a four-leaf rosette flanked by tendrills which fill the gable's corners form the pediment's decoration. The rectangular panel below shows a rich variety of depictions. A large wreath with great ribbons is placed in the the middle of the composition; inside the wreath a great hand mirror signalises that the monument is intended to be the tomb stone for a woman. The upper corners are filled with rosettes. In the lower corners a large basket filled with wool, a spindle and a distaff are sculpted. Above the basket is a double-sided comb is placed. All these items indicate that this stele was designed for a woman. Beneath the inset panel a large, but blank tabula ansata is carved out.

Date: Roman Imperial Period

\section{Funerary stone}

Marble stele; now in the garden of the museum. Inv. no: 2016/25; Findspot: İnegöl/Bursa. Dimensions: H.: $140 \mathrm{~cm}$; W.: $51 \mathrm{~cm}$; D.: 15 cm. Date: Roman Imperial Period
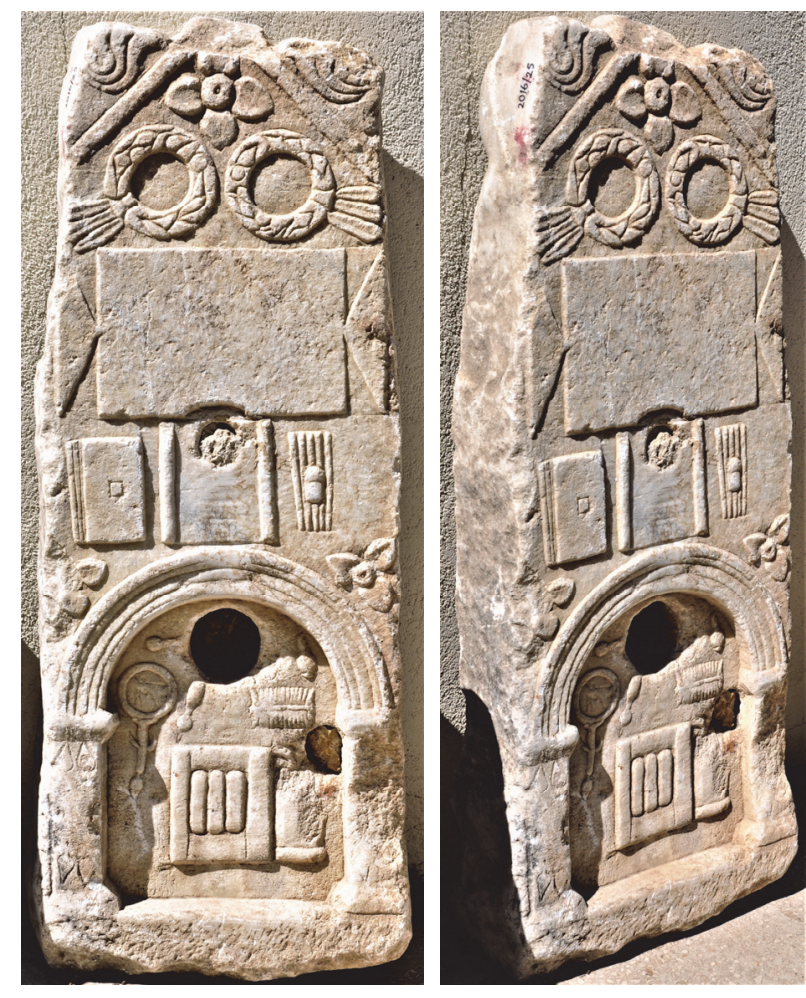

This tall stele is broken above; there are many breaks on the whole surface. The upper portion of the triangular pediment is damaged. In the pediment a somewhat clumsily hewn four-leaf rosette and beneath it two ribboned wreaths are carved out. Beneath the pediment a large, but blank tabula ansata is placed. Between a niche which took up the stele's lowest part and the tabula ansata a diptychon, a book roll, and a kalamotheke are depicted. In the niche there are some items belonging to a woman, a mirror with handle, a comb, a perfume flask, a chestlike object and some other objects unidentifiable because of the hole. The hole cut in the niche below was probably made to enable it to be used to face a water source.

Date: Roman Imperial Period 


\section{Monuments not preserved in the Bursa Museum}

\section{Funerary inscription of Lakaina}

Marble stele. Findspot unknown. Currently housed in the Directorate of Technical Works at Gemlik Municipality (Gemlik [Kios]/Bursa). Dimensions: H.: 62 cm; W.: 42-44 cm; D.: 11-14 cm; Lh.: $2-4 \mathrm{~cm}$.

The surface of the stele with triangular pediment is slightly weathered. Otherwise complete. The base is not preserved. The corner acroteria show floral decorations. In the middle of the pediment a small rosette is visible. In a rectangular panel a mirror, a wool basket, a spindle and a distaff are carved out. An inscription of five lines is written beneath the panel.
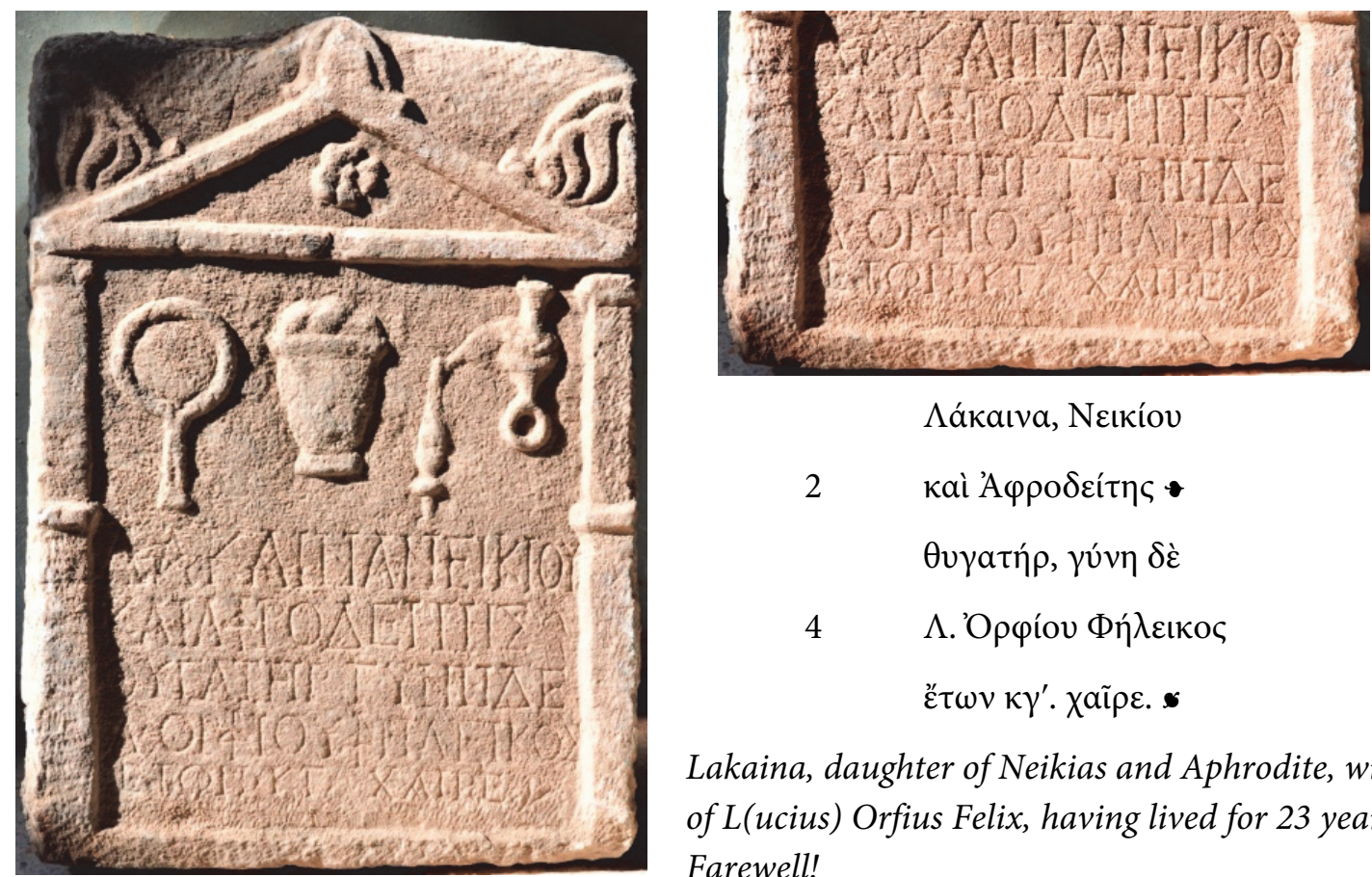

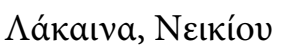

2

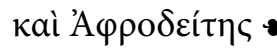

$\theta v \gamma \alpha \tau \eta ́ p, \gamma u ́ v \eta \delta \grave{\varepsilon}$

4

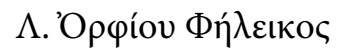

हैं $\omega v \kappa \gamma^{\prime} \cdot \chi \alpha \tilde{\imath} \rho \varepsilon$.

Lakaina, daughter of Neikias and Aphrodite, wife of L(ucius) Orfius Felix, having lived for 23 years. Farewell!

L. 1: To date, $\Lambda$ ákaıva appears to have been attested twice, one example in Ionia and the other in Lydia, see LGPN VA, 263 s.v.

L. 2: For the theophoric name Aphrodite in Asia Minor cf. LGPN VA, 93 s.v.; VB, 79 s.v.; VC, 80 s.v.; Herrmann - Malay 2007, 42-43, no. 26.

L. 4: There are at least 2 occurrences of this name in a list of prytaneis in Kyzikos, see Mordtmann 1881, 42, no. 1b, L. 3; Lolling 1888, 304, AIII, L. 26.

$\Phi \tilde{\eta} \lambda \varepsilon \xi \xi=\Phi \tilde{\eta} \lambda_{l} \xi$.

Date: Roman Imperial Period

\section{Funerary Inscription of Eia}

Marble stele. Findspot unknown. Currently kept in the Directorate of Technical Works at Gemlik Municipality (Gemlik [Kios]/Bursa). Dimensions: H.: 57 cm; W.: 38-42 cm; D.: 13 cm; Lh.: 2,5-3 $\mathrm{cm}$.

Slightly broken at the top left corner and at the bottom. The left side is damaged and gives the impression that it had submerged in water for a considerable time. Inside the triangular pediment a small rosette is cut out. Beneath the pediment a rectangular panel in which a seated girl holding 
an unidentifiable object in her right hand is depicted. She puts her feet on a footstool. In the right of the panel a large mirror with handle, a spindle and a distaff are sculpted. Below there is an insciption of five lines.

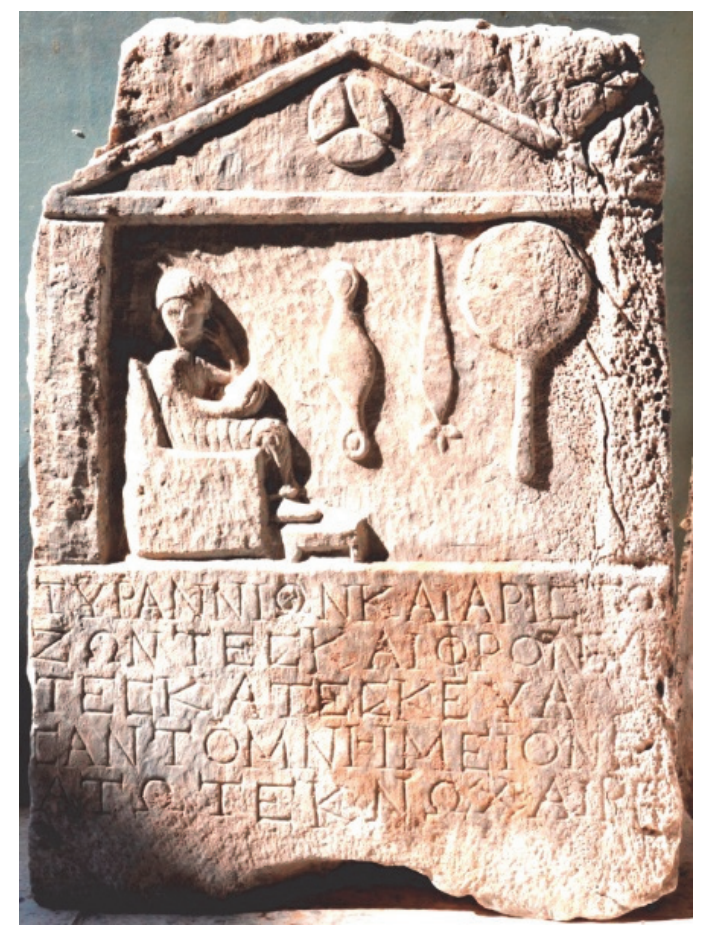

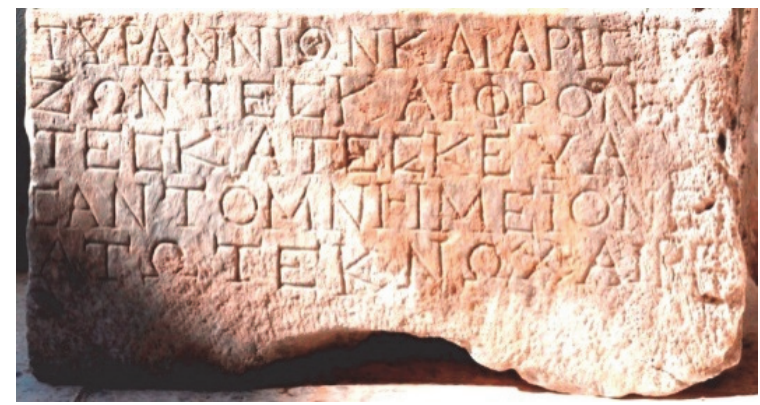

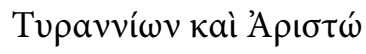

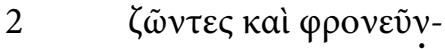

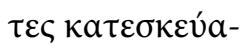

4

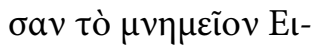

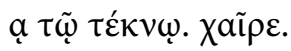

Tyrannion and Aristo, still living and clear-minded, constructed this tomb for their child Eia. Farewell!

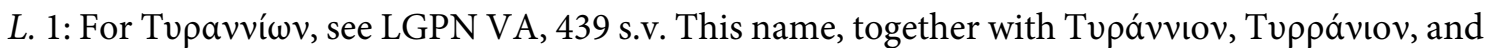
Tuppavíwv seem to be restricted to Ionia and Pontos.

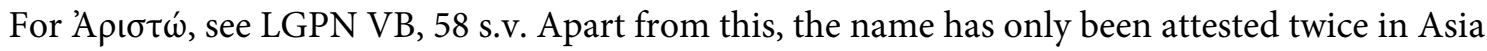
Minor (Caria and Cilicia Pedias).

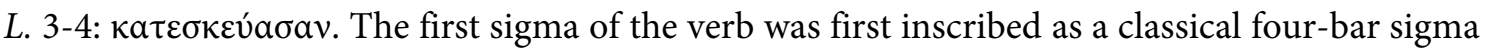
but then converted into a square form.

Date: Roman Imperial Period

\section{Funerary Monument of Phoibion and Teimothea}

White marble bomos with a stele on its front side. Discovered in the necropolis area in the Çiftlikköy excavations in Yalova. Its dimensions are unrecorded. The archaeologist Funda Ünal, who was working in the Bursa Museum, conducted the excavations and unearthed this and the following monument. We sincerely thank her for the photos, relevant information about the monuments, and finally for the permission to publish these monuments. The memorial consists of a bomos and a stele placed on it. The crown of the bomos has corner acroteria, between which a small Medusa/Gorgo head is placed. An inscription of seven lines is written on the shaft of the altar. The stele has a triangular pediment. In the rectangular panel beneath the pediment a ban-

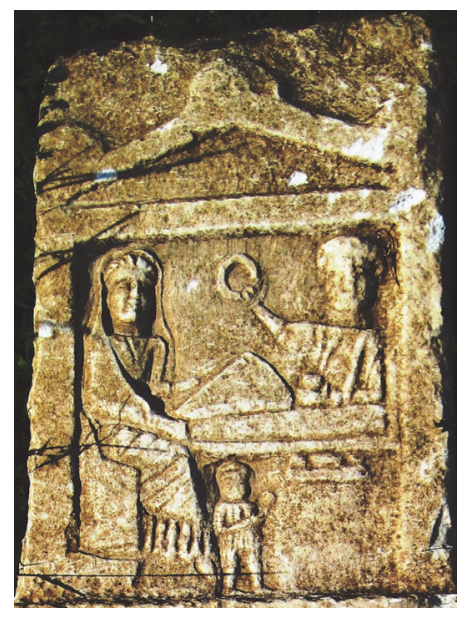
quet scene is represented. A man reclining on a couch holds a wreath in his right hand, and a woman in the pudicitia pose is sitting on a stool. A small figure in front of the woman may be 
identified as one of their two children or as a servant. The table in front of the couch seems to have been left unfinished.

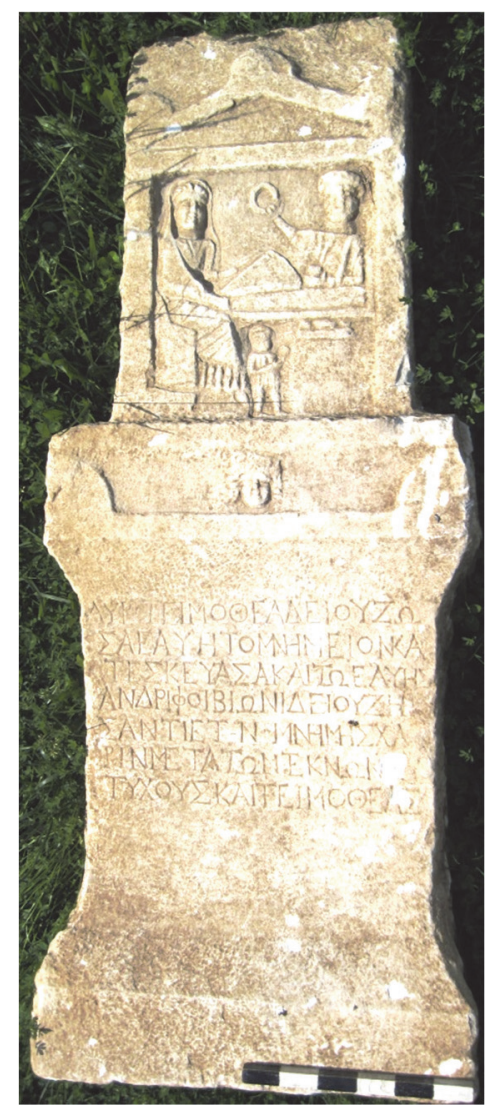

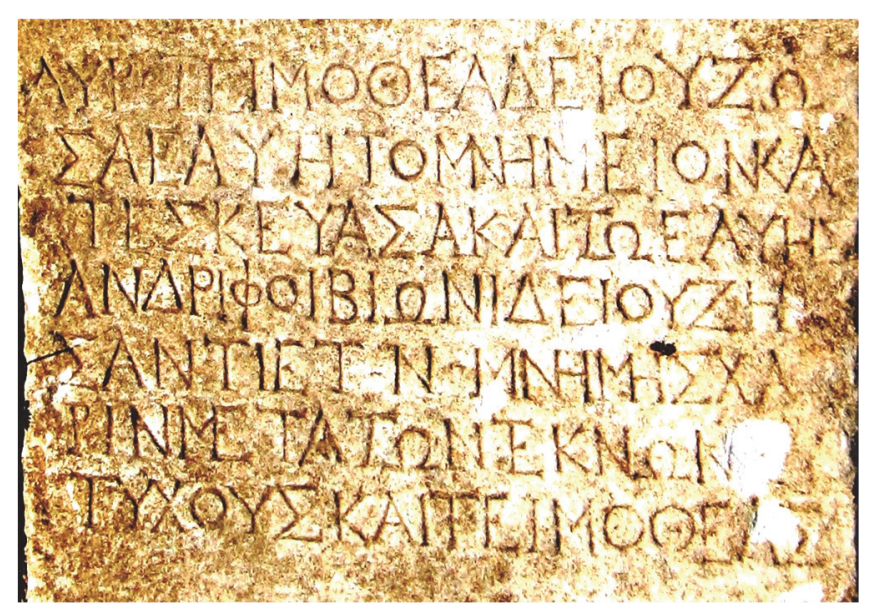

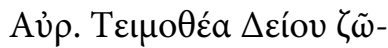

2

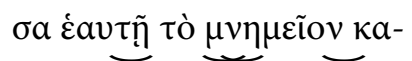

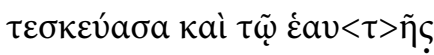

4

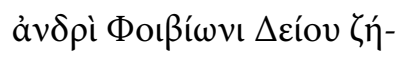

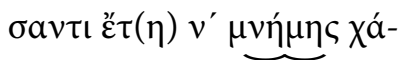

6

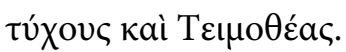

I, Aur(elia) Teimothea, daughter of Deios (or Deias), while still living have constructed this memorial for myself and for my husband Phoibion, son of Deios (or Deias), who lived 50 years, in remembrance of him. I did this together with my children Eutykhes and Teimothea.

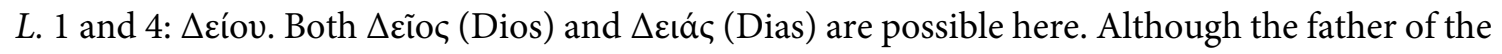
wife and the father of her husband have the same name, there is no reason to believe that the both Dios/Dias are identicial and that the persons buried were siblings. The phenomenon of brothersister marriages is almost entirely confined to Lycia in Roman Asia Minor, see Thonemann 2017, 155-156. Cf. Yildız 2018, 410.

L. 4: Фoıß $\hat{i}^{\prime} \omega v$ is not yet attested in Bithynia but is recorded twice in Mysia, see LGPN VA, 457 s.v.

This type of funerary monument is peculiar to Yalova (ancient Pylai). In almost all examples, a small Gorgo/Medusa head is depicted between the acroteria. For similar examples, see Pfuhl Möbius 1979, p. 463 nos. 1922, 1923, 1978, 1979 and pl. 277; IApameia-Pylai, p. 163-168 (p. 163 no. 198 fn. 1); p. 111-112 no. 106 and 107, pl. 3 and p. 154-156 no. 141-143 (= Mansel 1933, no. 1-2); Baz - Seçkin 2013, p. 394-396 nos. 6-7 fig. 7-8 (and possibly no. 8 and 9 fig. 9-10).

Date: After 212 A.D. (Constitutio Antoniniana).

\section{Funerary Bomos}

Fragment of a white marble bomos. Discovered in an area close to the excavation site in course of the Çiftlikköy excavations above mentioned. Dimensions unrecorded. 
The monument seems to be similar to the before discussed memorial. The stele and the lower portion of the bomos shaft are broken off and missing. The Medusa head between the acroteria is preserved. Only two lines from the inscription have remained intact.
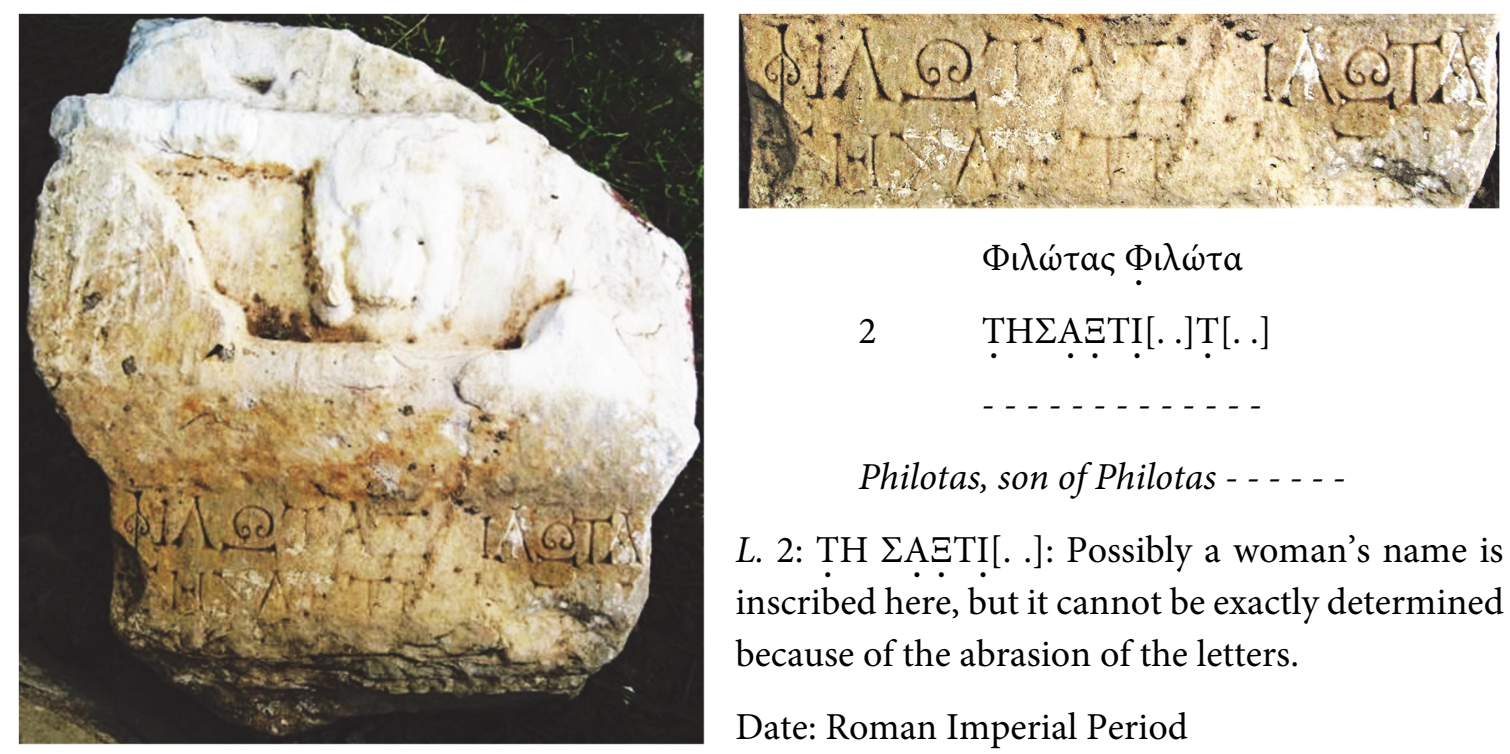

Philotas, son of Philotas - . - . -

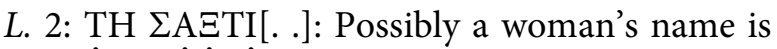
inscribed here, but it cannot be exactly determined because of the abrasion of the letters.

Date: Roman Imperial Period

\section{Inscription fragment}

Marble block; discovered in the late antique wall during the excavations in Zindankapı District (Pınarbaşı mahallesi). The inscribed block was apparently reused in the wall. Dimensions: H.: 75 cm; W.: 1,51 cm; D.: can't be measured; Lh.: 9-20 cm.

Broken at the left side and at the bottom; heavily damaged. Only a few letters from the Greek inscription are preserved. The script is irregular, and the second line is painted in a different colour. The dowel hole on the surface suggests that the stone had already before undergone a second usage. Some carvings above the first line of the inscription either belong to a decoration or to a different type of script.
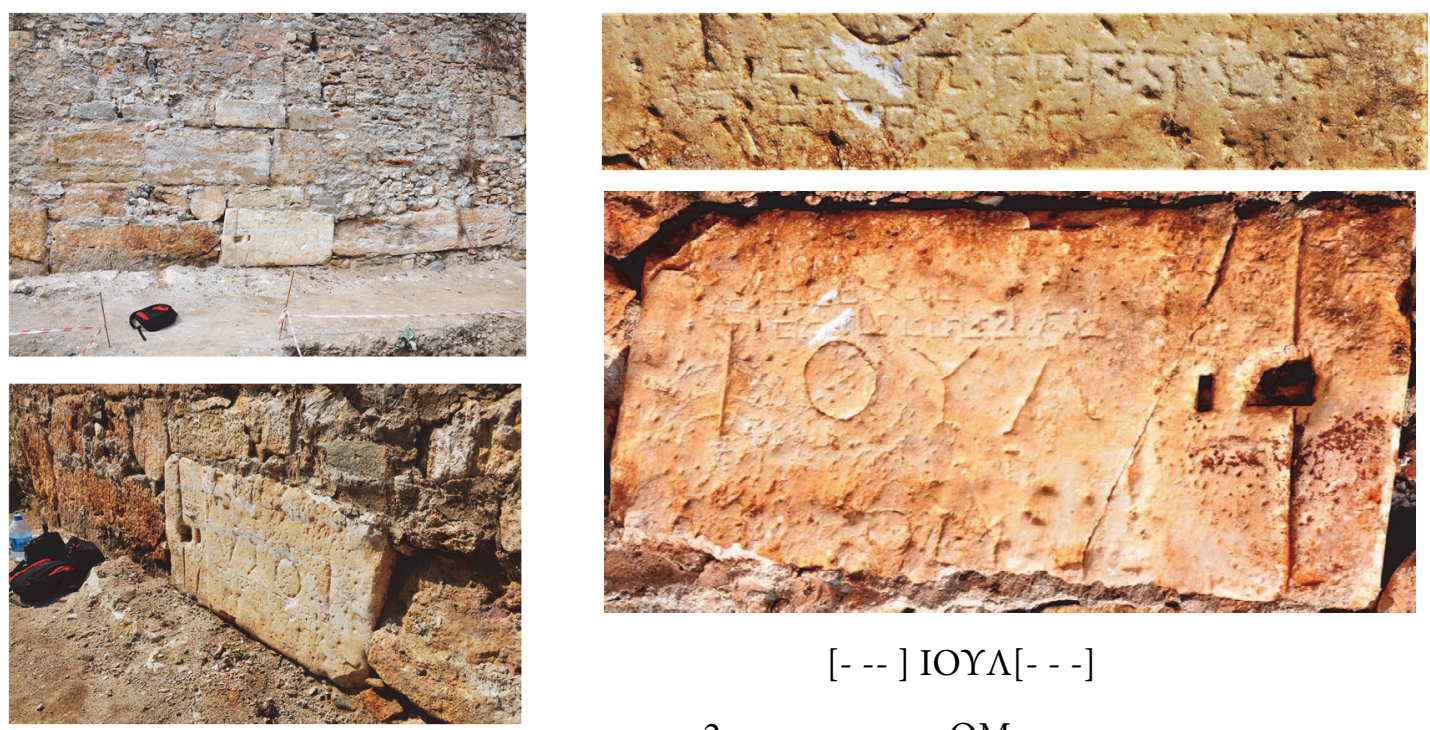

$$
\text { [--- ] IOY } \Lambda[---]
$$

2

$\mathrm{OM}$

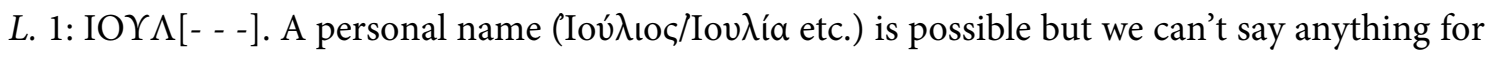
sure since it is very fragmentary.

Date: Roman Imperial Period 


\section{Index of Personal Names}

Акí入ıৎ? 17

'Акúৗas 4

'A $\lambda \varepsilon \xi \alpha \nu \delta \rho i ́ c 15$

А $\mu \mu \iota \alpha 14$

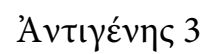

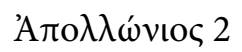

Apıбтаívetos 12

'Aрıбтокрátпৎ 3, 20

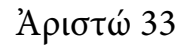

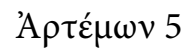

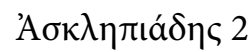

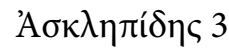

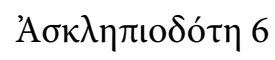

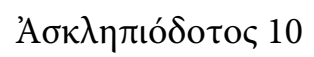

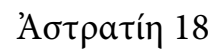

Aủp. 7, 10, 34

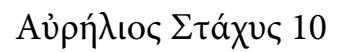

Apı́a 3

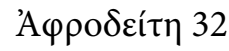

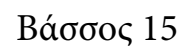

Bías 24

$\Gamma$ (aíoc) Moúpioc Oủá $\lambda\rceil \varsigma 22$

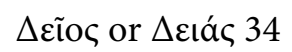

$\Delta \eta \mu \eta ́ \tau$ сољ 19

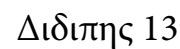

$\Delta$ ıіí́торıс 13

$\Delta$ เoүévๆৎ 17, 21

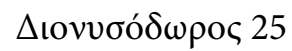

$\Delta$ ouítıৎ 12

$\Delta \omega$ píc 7

Eıa 33

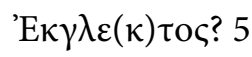

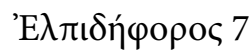

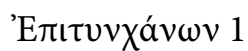

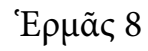

Eủpaíwv 3a

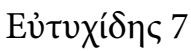

Eủนúxฤৎ 34

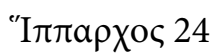

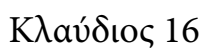

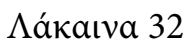

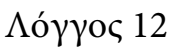

$\Lambda .{ }^{\prime} О \rho \varphi ı \varsigma ~ Ф \tilde{\eta} \lambda \varepsilon ı \xi 32$

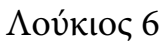

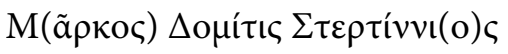

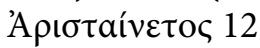

Maıvıa? 19

Maḱfua 12

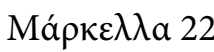

Ма̃ркоц 6, 12, 15

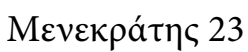

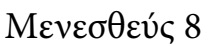

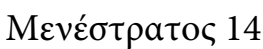

Mńvıos 3a

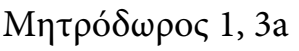

Mvaбéaৎ 14

Movpía Првíra 22

Moúpioc 22

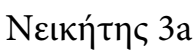

Neıкíac 32

Nevveoc 6

'О $\rho$ เос 32

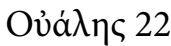

Патıаvóc? 9

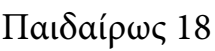

Паı $\delta \dot{\varepsilon} \rho \omega \varsigma 18$

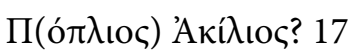

Пакі́入ıৎ? 17
По入v́aıvos 4

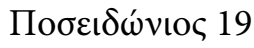

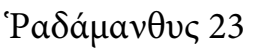

'Poṽ

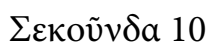

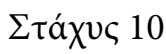

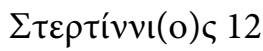

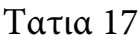

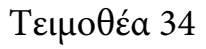

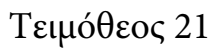

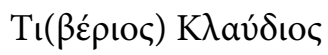

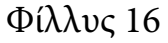

Торкобıvıия 13

Tupavvíwv 33

Фaßía'Poúpa 21

Фaßía Фáßov入a 11

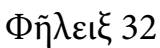

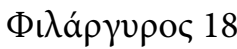

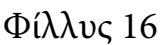

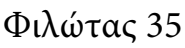

Фoıßíwv 34

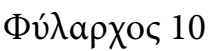

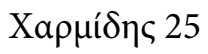

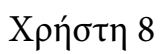

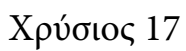

\section{Fragments}

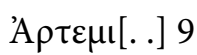

IOY $\Lambda$ [- - - ] 36

इЕПТІО[..] 13

[...]I·I·A 9

[...] $\delta \varepsilon \omega \varsigma 9$ 


\section{Bibliography}

$\mathrm{AE}$

Akın 2016

Akyürek Şahin 2010

Akyürek Şahin - Onur 2010

Anderson et al. 1910

Asgari 1977

Callan 2010

CIG

Cilliers - Retief 1999

Çaçu 2005

Dagron - Feissel 1987

Dana 2014
Cremer 1991

L'Année épigraphique.

Y. Akın, Küçük Asya'da Dağ ve Mağara Tanrıları. Meter Oreia Kültü ve İlgili Yazıtlar, in: N. Eda Akyürek Şahin - M. E. Yıldız H. Uzunoğlu (ed.), Eskiçağ Yazıları 8 [Akron 10], 143-203, İstanbul 2016.

N. E. Akyürek Şahin, Zwei neue Inschriften für Hosios kai Dikaios, Olba 18, 2010, 267-280.

N. E. Akyürek Şahin - F. Onur, Neue Grabinschriften im Museum von Bursa, Gephyra 7, 2010, 23-39.

J. G. C. Anderson - F. Cumont - H. Grégoire, Studia Pontica: Recueil des inscriptions grecques et latines du Pont et del'Arménie III, Brussels 1910.

N. Asgari, Die Halbfabrikate kleinasiatischer Girlandensarkophage und ihre Herkunft, Archäologischer Anzeiger, 1977, 329380.

Battistoni - Rothenhöfer 2013 F. Battistoni - P. Rothenhöfer, Inschriften aus dem Raum Keles und Orhaneli (Provinz Bursa, Türkei), EA 46, 2013, 101-165.

F. Baz - S. Seçkin, Neue Grabinschriften aus Pylai in Bithynien, Olba 21, 2013, 387-404.

G. E. Bean, Notes and Inscriptions from Pisidia. Part I, Anatolian Studies 9, 1959, 67-117.

C. Brixhe, Essai sur le grec anatolien au début de notre ère, nouvelle édition, Nancy 1987.

C. Brixhe, Corpus des inscriptions dialectales de Pamphylie. Supplément III, in: P. Goukovsky - C. Brixhe (ed.), Hellènika Symmikta. Histoire, archéologie, épigraphie, Nancy 1991, 15-27.

T. Callan, Prophecy and Oracles, in: M. Gagarin - E. Fantham (ed.), The Oxford Encyclopedia of Ancient Greece and Rome, Vol. I, Oxford 2010, 39-41.

Corpus Inscriptionum Graecarum.

L. Cilliers - F. P. Retief, Die helende hand: die rol van die vrou in die antieke geneeskunde, Acta Classica 42,1, 1999, 47-65.

M. Cremer, Hellenistisch-römische Grabstelen im nordwestlichen Kleinasien 1. Mysien (Asia Minor Studien 4,1), Bonn 1991.

A. Çaçu, Zeus Kersoullos. 1. Burza Turizm Sempozyumu, 30 Eylül - 2 Ekim, Bursa 2005, 453-468.

G. Dagron - D. Feissel, Inscriptions de Cilicie, Paris 1987.

D. Dana, Onomasticon Thracicum (OnomThrac): Répertoire des noms indigènes de Thrace, Macédoine Orientale, Mésies, Dacie et Bithynie, Athens 2014. 
Del Corso 2007

Detschew 1957

Dieterich 1898

Drew-Bear 1978

Dunst 1971

Flemming 2007

Fontenrose 1988

Ginouvès 1998

Heberdey - Kalinka 1897

Herrmann - Malay 2007

Höfer 1916-1924

IApameia-Pylai

IHadrianoi

IKalchedon

IKlaudiu Polis

IKios

ILaodikeia am Lykos

IPrusa ad Olympum I

IPrusa ad Olympum II

ISestos
L. Del Corso, Le pratiche scolastiche nelle testimonianze epigrafiche di età ellenistica, in: J. A. Fernández Delgado - F. Pordomingo - A. Stramaglia (eds.), Escuela y literatura en Grecia antigua. Actas del simposio internacional Universidad de Salamanca, 17-19 noviembre de 2004, Cassino 2007, 141-190.

D. Detschew, Die thrakischen Sprachreste, Wien 1957.

K. Dieterich, Untersuchungen zur Geschichte der griechischen Sprache, Leipzig 1898.

Th. Drew-Bear, Nouvelles Inscriptions de Phrygie, Zutphen 1978.

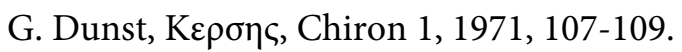

R. Flemming, Women, Writing and Medicine in the Classical World, Classical Quarterly 57, 2007, 257-279.

J. Fontenrose, Didyma. Apollo's Oracles, Cults and Companions, Berkeley-Los Angeles-London 1988.

R. Ginouvès, Dictionnaire méthodique de l'architecture grecque et romaine. Tome III. Espaces architecturaux, bâtiments et ensembles, Roma 1998.

R. Heberdey - E. Kalinka, Bericht über zwei Reisen im südwestlichen Kleinasien, Vienna 1897.

P. Herrmann - H. Malay, New Documents from Lydia (Österr. Akad. Wiss., Phil.-hist. Kl., Denkschr. 340, Erg. zu den TAM 24), Vienna 2007.

O. Höfer, s.v. Tauropoleites, in: W. H. Roscher (ed.), Ausführliches Lexikon der griechischen und römischen Mythologie V: T, Leipzig 1916-1924, 137.

Th. Corsten, Die Inschriften von Apameia (Bithynien) und Pylai (IK 32), Bonn 1987.

E. Schwertheim, Die Inschriften von Hadrianoi und Hadrianeia (IK 33), Bonn 1987.

R. Merkelbach, Die Inschriften von Kalchedon (IK 20), Bonn 1980.

F. Becker-Bertau, Die Inschriften von Klaudiu Polis (IK 31), Bonn 1986.

Th. Corsten, Die Inschriften von Kios (IK 29), Bonn 1985.

Th. Corsten, Die Inschriften von Laodikeia am Lykos, Teil I (IK 49), Bonn 1997.

Th. Corsten, Die Inschriften von Prusa ad Olympum, Teil I (IK 39), Bonn 1991.

Th. Corsten, Die Inschriften von Prusa ad Olympum II (IK 40), Bonn 1993.

J. Krauss, Die Inschriften von Sestos und der thrakischen Chersones (IK 19), Bonn 1980. 
ISmyrna II.1

IStratonikeia I

İplikçioğlu et al. 2007

Jones 2012

Kajanto 1965

Koch - Sichtermann 1982

Kubińska 1968

Kunnert 2012

Laes 2011

Laflı - Bru 2016

Lane 1976

Lehmler - Wörrle 2006

LGPN II

LGPN IIIA

LGPN VA

LGPN VB

LGPN VC

Lolling 1888
G. Petzl, Die Inschriften von Smyrna, Teil II.1 (IK 24,1), Bonn 1987.

M. Çetin Şahin, Die Inschriften von Stratonikeia, Teil I: Panamara (IK 21), Bonn 1981.

B. İplikçioğlu - G. Çelgin - A. V. Çelgin, Epigraphische Forschungen in Termessos und seinem Territorium IV, Vienna 2007.

C. P. Jones, Zeus Anabatênos and Zeus Kersoullos, ZPE 180, 2012, 233-236.

I. Kajanto, The Latin Cognomina, Helsinki 1965.

G. Koch - H. Sichtermann, Römische Sarkophage (Handbuch der Archäologie), München 1982.

J. Kubińska, Les monuments funéraires dans les inscriptions grecques de l'Asie Mineure, Warsaw 1968.

U. Kunnert, Bürger unter sich. Phylen in den Städten des kaiserzeitlichen Ostens, Basel 2012.

C. Laes, Midwives in Greek inscriptions in Hellenistic and Roman Antiquity, ZPE 2011, 154-162.

E. Lafl1 - H. Bru, Inscriptions et monuments funéraires grécoromains d'Anatolie occidentale, Anatolia Antiqua 24, 2016, 103116.

E. L. Lane, Corpus Monumentorum Religionis Dei Menis. Vol. III: Interpretations and Testimonia, Leiden 1976.

C. Lehmler - M. Wörrle, Neue Inschriften aus Aizanoi IV: Aizanitica Minora II, Chiron 36, 2006, 45-111.

M. J. Osborne - S. G. Byrne, A Lexicon of Greek Personal Names II. Attica, Oxford 1994.

P. M. Fraser - E. Matthews, A Lexicon of Greek Personal Names III A. The Peloponnese, Western Greece, Sicily and Magna Graecia, Oxford 1997.

Th. Corsten - R. W. V. Catling - M. Ricl, A Lexicon of Greek Personal Names VA. Coastal Asia Minor: Pontos to Ionia, Oxford 2010.

J. -S. Balzat - R. W. V. Catling - É. Chiricat - F. Marchand, A Lexicon of Greek Personal Names, Vol. V.B. Coastal Asia Minor: Caria to Cilicia, Oxford 2013.

J. -S. Balzat - R. W. V. Catling - É. Chiricat - Th. Corsten, A Lexicon of Greek Personal Names, Vol. VC: Inland Asia Minor, Oxford 2018.

H. G. Lolling, Inschrift aus Kyzikos, MDAI 13, 1888, 304-309. 
MAMA VII

MAMA IX

Mansel 1933

Marek 2006

Milner 1998

Mitchell 1977

Mitchell 1978

Mordtmann 1881

Nock 1925

Nollé 2009

Nordgren 2015

Onur 2011

Özlem-Aytaçlar 2010

Özlem-Aytaçlar 2012

Özdilek 2008
W. M. Calder, Monuments from Eastern Phrygia (MAMA VII), Manchester 1956.

B. Levick - St. Mitchell - J. Potter - M. Waelkens, Inscriptions from Aezani and the Aezanitis (MAMA IX), London 1988.

A. M. Mansel, Yalova'da Bulunan İki Mezar Taşı, Türk Arkeoloji Dergisi 1, 1933, 113-120.

Ch. Marek, Die Inschriften von Kaunos (Vestigia. Beiträge zur Alten Geschichte 65), Munich 1965.

N. P. Milner, An Epigraphical Survey in the Kibyra-Olbasa Region Conducted by A. S. Hall (Regional Epigraphic Catalogues of Asia Minor 3), Ankara 1998.

St. Mitchell, R.E.C.A.M. Notes and Studies No.1: Inscriptions of Ancyra, AS 27, 1977, 63-103.

St. Mitchell, Onomastic survey of Mysia and the Asiatic shore of the Propontis, in: Pulpudeva. Semaines philippopolitaines de l'histoire et de la culture thrace 2, Plovdiv, 4-19 octobre 1976, Sofia 1978, 119-127.

J. H. Mordtmann, Zur Epigraphik von Kyzikos, MDAI 6, 1881, 4055.

A. D. Nock, Studies in the Graeco-Roman Beliefs of the Empire, JHS 45, 1925, 84-101.

J. Nollé, Die taurische Artemis im Tauros: Zeugnisse und Überlegungen zum Artemiskult von Termessos in Pisidien, in: O. Tekin (Hrsg.), Ancient History, Numismatics and Epigraphy in the Mediterranean World. Studies in memory of Clemens E. Bosch and Sabahat Atlan and in honour of Nezahat Baydur, İstanbul 2009, 275-289.

L. Nordgren, Greek Interjections. Syntax, Semantics and Pragmatics, Berlin-Boston 2015.

F. Onur, New inscriptions from Hadrianoi pros Olympon (Mysia), Olba 19, 2011, 331-348.

P. Özlem-Aytaçlar, An Onomastic Survey of the Indigenous Population of North-western Asia Minor, in: R. W. V. Catling - F. Marchand (edd.), Onomatologos. Studies in Greek Personal names presented to Elaine Matthews, Oxford 2010, 506-529.

P. Özlem-Aytaçlar, Kuzeybatı Küçük Asya’nın Yerel Halklarının Onomastiği Üzerine Bir Araştırma, in: N. E. Akyürek Şahin - B. Takmer - F. Onur (edd.), Akron 1. Eskiçağ Yazıları 1, Antalya 2012, 63-113.

B. Özdilek, Neapolis Nekropolleri Üzerine Bir Ön-Rapor, in: II.-

IV. Ulusal Arkeoloji Araştırmalar Sempozyumu, Anadolu/ 
Özdilek - Çevik 2009

Pape - Benseler 1884

Paz de Hoz 2007

Paz de Hoz 2015

Pfuhl - Möbius 1979

Pleket 1981

Ripollès et al. 2015

Robert 1948

Robert - Robert 1948

Robert 1964

Robert, OMS I

Robert, OMS VI

Rodríguez Pérez 2010
Anatolia, Ek Dizi No. 2/Supplement Series Nr. 2, Ankara 2008, 235-252.

B. Özdilek - N. Çevik, New Discoveries in Rural North East Lycia: Scenes of Daily Life on Roman Rural Sarcophagi, in: Ç. Özkan Aygün (ed.), SOMA 2007. Proceedings of the XI Symposium on Mediterranean Archaeology, Istanbul Technical University, 24-29 April 2007 (BAR International Series 1900), 2009, 284-290.

W. Pape - G. E. Benseler, Wörterbuch der griechischen Eigennamen, Vol. 2, Braunschweig 1884.

M. Paz de Hoz, Testimonios epigráficos sobre la educación griega de época imperial, in: J. A. Fernández Delgado - F. Pordomingo A. Stramaglia (eds.), Escuela y literatura en Grecia antigua. Actas del simposio internacional Universidad de Salamanca, 17-19 noviembre de 2004, Cassino 2007, 307-332.

M. Paz de Hoz, Associations of Physicians and Teachers in Asia Minor: Between Private and Public, in: V. Gabrielsen- Ch. A. Thomsen (eds.), Private Associations and the Public Sphere: Proceedings of a Symposium held at the Royal Danish Academy of Sciences and Letters, 9-11 September 2010, Copenhagen 2015, $92-$ 121.

E. Pfuhl - H. Möbius, Die ostgriechischen Grabreliefs II, Mainz 1979.

H. W. Pleket, Religious history as the history of mentality: the 〈believer〉 as servant of the deity in the Greek World, in: H. S. Versnel (ed.), Faith, Hope and Worship, Leiden 1981, 152-192.

P. P. Ripollès - A. Burnett - M. Amandry - I. Carradice - M. S. Butcher, Roman Provincial Coinage. Consolidated Supplement III, 2015 (https://rpc.ashmus.ox.ac.uk/supp/rpc_cons_supp_13.pdf- Access: 08.03.2019).

L. Robert, Hellenica V, Paris 1948.

L. Robert - J. Robert, Hellenica, Recueil d'épigraphie, de numismatique et d'antiquités grecques publié par L. Robert. Vol. VI. Inscriptions grecques de Lydie, Paris 1948.

L. Robert, L'édition et l'index commenté des épitaphes, in: N. Firatll, Les stèles funéraires de Byzance gréco-romaine, Paris 1964, 131-189.

L. Robert, Opera Minora Selecta. Épigraphie et antiquités grecques, Tome I, Amsterdam 1969.

L. Robert, Opera Minora Selecta. Épigraphie et antiquités grecques, Tome VI, Amsterdam 1989.

D. Rodríguez Pérez, Contextualizing Symbols: «the Eagle and the Snake» in the Ancient Greek World, Boreas 33, 2010, 1-18. 
Ruge 1934

Saller 1994

Samama 2003

Scheidel 2007

Schulze 1991

Schwabl 1993

Schwertheim 1989

SGO II

SGO III

Solin 2004

Şahin 1974

Talloen 2015

TAM V, 1

TAM V,2

Tanriver 2013
W. Ruge, s.v. Tauropolis (3), in: RE VA, 1, 1934, 33-34.

R. P. Saller, Patriarchy, Property and Death in the Roman Family, Cambridge 1994.

E. Samama, Les médecins dans le monde grec: sources épigraphiques sur la naissance d'un corps médical, Geneva 2003.

W. Scheidel, Roman Funerary Commemoration and the Age at First Marriage, Classical Philology 102,4, 2007, 389-402.

W. Schulze, Zur Geschichte lateinischer Eigennamen, mit einer Berichtigungsliste zur Neuausgabe von Olli Salomies, Hildesheim 1991.

H. Schwabl, Zum Kult des Zeus in Kleinasien, in: G. Dobesch - G. Rehrenböck (Hrsg.), Die epigraphische und altertumskundliche Erforschung Kleinasiens: Hundert Jahre Kleinasiatische Kommission der Österreichischen Akademie der Wissenschaften. Akten des Symposiums vom 23. bis 25. Oktober 1990, Vienna 1993, 329-338.

E. Schwertheim, Die Heimat des Aelius Aristides, in: H. -J. Drexhage - J. Sünske (ed.), Migratio et commutatio: Studien zur alten Geschichte und deren Nachleben: Thomas Pekáry zum 60. Geburtstag am 13. September 1989 dargebracht von Freunden, Kollegen und Schülern, St. Katharinen 1989, 249-257.

R. Merkelbach - J. Stauber, Steinepigramme aus dem griechischen Osten II. Die Nordküste Kleinasiens (Marmarameer und Pontos), München-Leipzig 2001.

R. Merkelbach - J. Stauber, Steinepigramme aus dem griechischen Osten III. Der ferne Osten und das Landesinnere bis zum Tauros, München-Leipzig 2001.

H. Solin, Analecta epigraphica CCXVI-CCXXII, Arctos XXXVIII, 2004, 163-205.

S. Şahin, Neufunde von antiken Inschriften in Nikomedeia (İzmit) und in der Umgebung der Stadt, Münster 1974.

P. Talloen, Cult in Pisidia. Religious Practice in Southwestern Asia Minor from Alexander the Great to the Rise of Christianity, Turnhout 2015.

P. Herrmann, Tituli Asiae Minoris V: Tituli Lydiae linguis Graeca et Latina conscripti, Fasc. 1: nos. 1-825, Regio septentrionalis ad occidentem vergens, Vienna 1981.

P. Herrmann, Tituli Asiae Minoris V: Tituli Lydiae linguis Graeca et Latina conscripti, Fasc. 2: nos. 826-1414, Regio septentrionalis ad occidentem vergens, Vienna 1989.

C. Tanriver, Mysia'dan Yeni Epigrafik Buluntular, İzmir 2013. 
Taeuber 2016

Thonemann 2013

Thonemann 2017

Uzunoğlu 2015

Uzunoğlu 2019

Waldmann 1978

Ylldız 2018

Ylldız 2019

Zahle 1979

Zgusta 1964
H. Tauber, Zu einer Grabstele aus İnegöl (Bursa), in: Adnotationes Epigraphicae VII, Tyche 31, 2016, 285-290.

P. Thonemann, Households and families in Roman Phrygia, in: P. Thonemann (ed.), Roman Phrygia. Culture and Society, Cambridge 2013, 124-142.

P. Thonemann, Close-Kin Marriage in Roman Anatolia, The Cambridge Classical Journal 63, 2017, 143-166.

H. Uzunoğlu, Bursa Müzesi’nden Ölü Ziyafeti Sahneli Yeni Mezar Stelleri, Olba 23, 397-415.

H. Uzunoğlu, Phrygia'dan Bir Grup Yeni Mezar Steli, Mediterranean Journal of Humanities IX/1, 2019, in print.

H. Waldmann, Ein Archimystes in Sagalassos, in: M. de Boer - T. A. Edridge (ed.), Hommages à Maarten J. Vermaseren, Volume 3, Leiden 1978, 1309-1315.

M. E. Yıldız, Tlos’tan İki Yeni Mezar Yazıtı, Olba XXVI, 2018, 405414.

M. E. Yıldız, Epigramm auf die verstorbene Moschion. Eine neue Grabstele aus dem Territorium von Miletupolis in Mysien, in: M. Nollé - P. M. Rothenhöfer - G. Schmied-Kowarzik - H. Schwarz - H. Ch. von Mosch (eds.), Panegyrikoi Logoi. Festschrift für Johannes Nollé zum 65. Geburtstag, Bonn 2019, 583-590.

J. Zahle, Lykische Felsgräber mit Reliefs aus dem 4. Jahrhundert v. Chr. JbDAI 94, 1979, 245-346.

L. Zgusta, Kleinasiatische Personennamen, Prag 1964.

\section{Bursa Müzesi'nden Yeni Yazıtlar}

Özet

Bu makalede Bursa müzesindeki bir grup Eski Yunanca yazıtlı yeni eser tanıtılmaktadır. Burada yayımlanan 36 eserin ilk 4 tanesi adak, geriye kalan eserler ise mezar taşıdır. Mezar taşlarından altı tanesinde (no. 26-31) yazıt yoktur, fakat bu eserlerin de bilim dünyasında tanınması için makaleye onlar da alınmıştır. Bu yazıtsız eserler olasılıkla atölyelerde üretilmiş ve hiç bir zaman bir müşteriye satılmamış ve mezar taşı olarak kullanılmamıştır. Mezar yazıtlarından bazıları (no. 2125) Laflı ve Bru (2016) tarafından müzede bizim çalışmamıza rağmen ve müzeden izinsiz biçimde daha önce yayımlanmıştır. Bu yazıtların bazıları tarafımızdan burada düzeltilmiştir. Makalede bazılarının buluntu yerleri bilinmemekle birlikte eserlerin genellikle Bursa ve çevresinde bulundukları görülmektedir. Buluntu yerleri olarak Bursa'da Nilüfer, İnegöl, Orhaneli, Harmancık, Keles, Gemlik, Karacabey, Orhangazi ve Mudanya ilçeleri ile Yalova ili görülmektedir. Adak yazıtları bize Meter Taurene, Men Tauropoleites, Zeus Kersoullos ve Apollon gibi tanrıların isimlerini vermektedir. İlk iki tanrı Mysia bölgesinde tapınım gören tanrılardan değildirler ve kültlerini olasılıkla Küçük Asya’nın güney batı bölgelerinde aramak gerekmektedir.

Makalede tanıtılan mezar taşlarının ise lahit, prizma biçimli altar, silindir altar, stel, ölü yemeği sahneli stel ve de altar üzerinde stel olarak karşımıza çıktığı görülmektedir. Zengin bir mezar taşı 
tipolojisi vardır. Buradaki yazıtlar da Mysia bölgesinin onomastiği hakkında bilgilerimizi zenginleştirmektedir. Basit de olsa mezar yazıtlarından bir azatlı (no. 5), Protinia isimli bir phyle (no. 10), bir demos'un bir kadın doktoru onurlandırması (no. 11), bir öğretmen (no. 16) gibi bilgiler de edinilmektedir. Yazıtlar büyük oranda Roma İmparatorluk Dönemi'nin 2. ve 3. yüzyıllarına aittir. Ancak olasılıkla Hellenistik Dönem'e ait birkaç yazıt da vardır (no. 13, 19, 24, 25).

Yazıtların çevirileri şöyledir:

1. Epitynkhanon'un oğlu Metrodoros (bunu) Meter Taurene ve Men Tauropoleites için adak olarak (sundu).

2. Hayırlı uğurlu olsun! Asklepiades'in oğlu, Aoriasse köyünden Ankyra vatandaşı Apollonios (bu sütunu tanrının) emri uyarınca, gizli ayinlerin başkanı Rufus'un kâhinlik (profetlik) yaptığı sırada Zeus Kersoullos'a adadi.

3. Hayırlı uğurlu olsun! Asklepides oğlu Antigenes ve Aphia bu sekos'u (kutsal yeri?) masraflarını kendileri karşılayarak rahip Aristokrates'in kâhinlik (profetlik) yaptı̆̆ı sırada tanrıya adadılar.

3a. Hayırl uğurlu olsun! Menios'un oğlu Metrodoros (ve) Euraion Neiketes kötü mevsimler (nedeniyle?) ve kendileri için adağı - . - . - - kâhinlik (profetlik) yaptı̆̆ı sırada (sundular).

4. Apollon? [Ak]raios? için bu altarı (tanrının) emri uyarınca Akylas'ın oğlu Polyainos eşi ile beraber dikti.

5. Artemon'un azatlisı ey Ekgle(k)tos, elveda!

6. Marcus'un oğlu Lucius (bu altarı) yaşarken kendisi için ve kendi (eşi) Nennis'in kızı Asklepiodote için (yaptırdl).

7. Aur(elia) Doris çocukları Elpidephoros ve Eutykhides ile beraber biricik kocası Eutykhides için anısı nedeniyle (bu altarı dikti).

8. Menestheus oğlu Hermas eşi Khreste için onun anısı nedeniyle (bu mezarı) parasını kendisi ödeyerek (yaptırdi).

9. Papianus'un? oğlu - - - - - - ve onun karısı - - ia Artemi- - - kocası/karısı - - des'in oğlu/kızı S- - - için anısı nedeniyle (bu mezarı yaptırdı).

10. Ben Asklepiodotos'un oğlu, Protinia phylesi'nden phylarkhos Aurelius Stakhys hayattayken bu mezarı kendim için ve biricik eşim Secunda ve biricik çocuklarım için yaptırdım.

11. Demos (insanlar) mütevazı bir şekilde hayat sürmüşs olan kadın doktor (ebe?) Fabia Fabula'yı (ölümünden sonra onurlandirdl).

12. Bu mezarı, M(arcus) Domiti(o)s Stertinni(o)s Aristainetos pek tatl hayat arkadaşı Longus'un kızı Maxima için (yaptırdı).

13. Diliporis'in oğlu Torkosinies - - - - - yaptırdı. Onun damadı Didipes'in oğlu - - - - -. Elveda!

14. Mnaseas'in kızı, Menestratos'un ise eşi Ammia. Elveda!

15. Marcus'un kızı, Bassus'un ise eşi 15 yaşındaki Aleksandris için.

16. Öğretmen Claudius Phillys'ün oğlu 15 yaşındaki Tiberius Claudius Phillys için.

17. P(ublius) Acilius (veya Pakilios) bir ismi de Khrysios olan Diogenes'in kızı olan eşi, cömert? Tatia için hayattayken - - (bu mezarı yaptırdı). 
18. Philargyros'un oğlu 6 (veya 7) yaşındaki Paideros için. Philargyros ve Astratie? kendi oğulları Paideros için bu mezarı (yaptırdılar).

19. Poseidonios'un oğlu Demetrios (ve) eşi Mainia?. Elveda!

20. Aristokrates'in oğlu - - - - - onun - - -

21. Selam ey yoldan geçen! Örnek biçimde 60 yll yaşam sürmüş olan Diogenes'in oğlu Diogenes; vah ki ne vah! Teimotheos'un oğlu Diogenes 12 yll birlikte yaşam sürdüğ̈̈ kendi eşi Fabia Rufa için; (ki) o 25 yaşını tamamladı; (bu) steli hatırası nedeniyle yaptırdı.

22. Henüz hayatta olan G(aius) Murius Valens ve Muria Prima için ve onların oğulları 22 yıl yaşamış olan Rufus için. (Bu) steli kızları Marcella yaptırdı.

23. Menekrates'in oğlu Rhadamanthys. Elveda!

24. Bias'in oğlu ey Hipparkhos, elveda!

25. Dionysodoros'un oğlu Kharmides.

32. Neikias ve Aphrodite’nin kızları, L(ucius) Orfius Felix’in ise eşi, 23 yaşındaki Lakaina. Elveda!

33. Tyrannion ve Aristo yaşarken ve akılları yerindeyken (bu) mezarı çocukları Eia için yaptırdılar. Elveda!

34. Ben, Deios'un (veya Deias'ın) kızı Aur(elia) Teimothea henüz hayatta iken kendim için ve 50 sene yaşayan kocam Deios (veya Deias) oğlu Phoibion'un hatırası nedeniyle bu mezar anıtını çocuklarım Eutykhes ve Teimothea ile birlikte yaptırdım.

35. Philotas'in oğlu Philotas - . . - -

36. Fragman.

Anahtar sözcükler: Bursa Müzesi, adak ve mezar yazıtları, Meter Taurene, Men Tauropeleites, Zeus Kersoullos, prophetes, kadın doktor, paideutes.

\section{New Inscriptions from the Museum of Bursa}

Abstract

In this contribution we introduce some new ancient Greek inscriptions from the Bursa Museum. Of the 36 artefacts, the first four are dedications, while the remaining are funerary stones. Six funerary stelai do not bear any inscriptions. The provenance of some artefacts unfortunately remain unknown, but in general they were brought to the museum from Bursa province and its environs such as the districts of Nilüfer, İnegöl, Orhaneli, Harmancık, Keles, Gemlik, Karacabey and Orhangazi, as well as from the province of Yalova. The ex-votos are offered to Meter Taurene, Men Tauropoleites, Zeus Kersoullos and Apollon. The funerary inscriptions are humble, but apart from contributing to the already rich onomastics of Bithynia Mysia, they also provide some interesting information, such as concerning a freedman (no. 5), a new phyle called Protinia (no. 10), the posthumous honouring of a woman doctor (no. 11), and, a teacher (no. 16). The inscriptions mostly date to the Roman Imperial Period, but there are also a few Hellenistic examples (nos. 13, $19,24,25)$.

Keywords: Bursa Museum, ex-votos and funerary inscriptions, Meter Taurene, Men Tauropeleites, Zeus Kersoullos, prophetes, female doctor, paideutes. 